\title{
Interpreting Graffiti in the Saqqara New Kingdom Necropolis as Expressions of Popular Customs and Beliefs
}

\author{
W. Paul van Pelt, Nico Staring
}

Previous examinations of ancient Egyptian graffiti have focused on textual graffiti and developed interpretations specific to this class of evidence. In contrast, relatively few studies have considered the communicative power and meaning of figural graffiti, presumably because of the inherent challenges that this data set presents to academic research. To counterbalance the current emphasis on textual graffiti, this contribution examines graffiti making in the New Kingdom necropolis at Saqqara using an integrated approach taking in both textual and figural material. In accordance with the imagistic principle of Egyptian magic, the authors propose that certain types of figural graffiti may be regarded as pictorial prayers in their own right, intended to ensure the permanent presence of the graffitist in the tomb, or to protect and beatify the deceased in the afterlife. Since literacy is not a prerequisite for drawing a picture, the important question is raised of whether the production of figural graffiti expanded throughout the social scale or, like textual graffiti, was restricted to the elite and sub-elite.

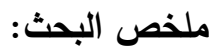

الدراسات السابقة التي تم إجراؤها على الكتابة و النقوش الجدارية المصرية القديمة ركّت إهتمامها على تفسيرات معينة لهذا النوع من الأدلة. في المقابل تتاولت بعض الدراسات القوة التعبيرية والمعنى من وراء النقوش التصويرية، على الأرجح بسبب التهاب

التحديات التي توفرها مجموعة البيانات هذه إلى البحث الأكاديمي. لإمكانية موازنة الجهود الحالية المبذولة في الكتابات و الرسومات الجدارية، تدرس هذه المقالة صناعة الرسومات الجدارية في مقبرة تعود إلى الدولة الحديثة في سقارة بإستخدام نهج متكامل يتتاول كل من المواد النصية والتصويرية. وفقاً للمبدأ التصويري للسحر المصري، يقترح المؤلفون وجود بعض أنواع من النقوش الجدارية يمكن إعتبارها على أنها صلوات مصوّرة في حد ذاتها وهي تهدف إلى ضمان التواجد الدائم للنقوش في المقبرة، أو لحماية المتوفى أو منحه السعادة الأبدية في الحياة الآخرة. بما أن معرفة القراءة والكتابة ليست شرطاً أساسياً لرسم صورة ما، فإن السؤال المهم الذي يطرح نفسه الآن هو ما إذا كان إنتاج الرسومات الجدارية يمتد عبر النطاق الإجتماعي أم أنه يقتصر على النبلاء ومن يحيط بهم فقط على غرار النقوش النصية.

"Graffiti is one of the few tools you have if you have almost nothing."

Banksy (2001)

\section{Introduction}

In addition to formal reliefs and texts, the tombs of the Saqqara New Kingdom necropolis bear hundreds of unofficial inscriptions and depictions, some incised, some executed in red or black pigment. ${ }^{1}$ These "graffiti" dating to the Pharaonic Period are a commonplace phenomenon in the Nile Valley and its surrounding deserts, and depict humans, animals and different kinds of objects. ${ }^{2}$ Despite their proliferation, until recently there were very few monuments in Egypt for which a complete inventory of the graffiti had been published, ${ }^{3}$ and several publications tended to consider only textual graffiti. ${ }^{4}$ Traditionally, non-textual or figural graffiti were rarely noted or recorded. Instead, they were often perceived as "visual noise", obscuring the aesthetics of the tomb 
or temple decoration, or as mindless defacements of monuments. While this preoccupation with written evidence has been somewhat symptomatic for Egyptological studies on the whole, it is also partly due to the inherent challenges that figural graffiti present to academic research. ${ }^{5}$ In general, they have proven difficult to date and interpret because the images vary greatly in quality and in the manner in which they are executed. Some are incised deep into the stonework and elaborately drawn, while others are little more than superficial, crudely-executed scratches. Yet the main challenge in documenting them lies not per se in the interpretation of the objects they depict, but in the interpretation of their meaning, attempting to answer such questions as: "why was this graffito made?", "why was it made in this location?", and "who was the graffitist?" In many cases, the best that can be expected is to identify reasonable possibilities by comparing the likeness of the graffito to analogous motifs and symbols, and by studying the graffito's relationship to its surrounding architecture, installations, and other objects inside the relevant space.

Notwithstanding the challenging nature of their interpretation, figural graffiti are of genuine interest and significance to scholarship. Textual and figural graffiti are both embedded in a built as well as a social environment, and provide mementoes of former visitors to a monument and clues about how people interacted with functioning or possibly desolate structures. They represent categories of tangible proof of the reception of a structure and about its “resonance", albeit negative or positive. Understanding this resonance will allow researchers to address important social questions such as who does what, where, when, including or excluding whom, and why, for any sort of structure. ${ }^{7}$ More interestingly still, textual and figural graffiti may provide different windows into history. When literacy was the accomplishment of a minority, as was the case in New Kingdom Egypt, ${ }^{8}$ written graffiti were without doubt mainly the work of scribes or literate individuals belonging to the elite and sub-elite administration. ${ }^{9}$ It is no wonder, therefore, that traditional accounts of written graffiti paint a somewhat tautological picture of a literate section of society visiting necropolises and leaving graffiti. ${ }^{10}$ However, there is no ob- vious reason to assume that figural graffiti should necessarily be interpreted within a similar framework. ${ }^{11}$ Rather, the question arises whether figural graffiti were just as socially restricted as their textual counterparts, or whether they may reflect a means of recorded expression for the illiterate and/or less literate section(s) of the Egyptian population to make reference to popular customs and beliefs. ${ }^{12}$ The vast majority of the figural graffiti in the New Kingdom tombs at Saqqara do not convey the impression of being created by an (artistically-)educated section of society. Rather, they may well have been created by a broad variety of people: commoner, priest, or nobleman; man, woman, or child, whether literate or not. Thus, while written graffiti express the perspectives of the educated elite and sub-elite, figural graffiti may cross social divides and reveal folk practices and beliefs that have left a mark in them. This potential interaction between different groups participating in the same social system and built environment would be of particular interest and make figural graffiti an exciting data source to illuminate a previously shadowy area of Egyptian religious history: the study of aspects of popular piety. ${ }^{13}$

Such were the considerations which motivated the authors to undertake the first systematic largescale survey of textual and figural graffiti in the New Kingdom necropolis at Saqqara (Leiden-Turin concession area). ${ }^{14}$ The latter provides a privileged setting for a holistic analysis of graffiti because it is a well-preserved space with a substantial corpus of published textual and figural material. ${ }^{15}$ This may allow observations that shed light on the motivations behind both categories of graffiti, and may facilitate an assessment of their relative cultural significance. Rather than discussing all the graffiti recorded so far, many of which are badly eroded and largely indecipherable, this contribution provides a summary of some of the more significant and evocative discoveries. It first considers the content and form of particular groups of textual and figural graffiti and assigns them to provisional classifications based on their purpose, distinguishing between devotional, ritual, and secular graffiti. ${ }^{16}$ It then investigates the spatial distribution and relative importance of textual and figural graffiti, as this may provide insights into how space was used, where textual and figural 
graffiti have a tendency to appear, and in what way textual and figural graffiti were conditioned by the space in which they were executed. However, as a preliminary it may be useful to define what is meant by "graffiti" in this contribution. ${ }^{17}$ This contribution continues to use the term in the somewhat inconsistent Egyptological manner, extending the narrow etymological sense of the word (from graffiare, "to scratch") to include all deliberately "added" markings that are either incised into, scratched on, or painted onto the tomb's architectural features. ${ }^{18}$

\section{Function and content \\ 2.1 Graffiti as a devotional act}

Today the word "graffiti" tends to carry a negative connotation and conjure up images of vandalism. However, ancient Egyptian attitudes towards graffiti appear to have been very different and largely lacked the modern connotations that associate graffiti with destruction, defacement, and lawlessness. ${ }^{19}$ Because of the inherent magic of texts and images, ${ }^{20}$ graffiti had the capacity to be benevolent, commemorative expressions that kept the names and identities of individuals magically alive and communicated them to contemporary and future generations. ${ }^{21}$ When applied in temples and tombs, graffiti were also a means of contacting the deceased and the gods of the necropolis. ${ }^{22}$ Such a desire for "otherworldly" interaction is made explicit in the socalled "piety-oriented" graffiti, in which the graffitist invokes the deities of a site, not only on behalf of himself but occasionally also on behalf of family members. ${ }^{23}$ Although not stated as unambiguously, certain groups of figural graffiti also seem to aim to interact with an eternal audience, such as the incised footprints or sandals (plantae pedis) on the pavement of the tomb of Maya and Meryt (Figs. 1$)^{24}$ and on a statue niche in the tomb of Horemheb (Fig. 2). ${ }^{25}$ Such graffiti are relatively commonplace along the Nile Valley, and are also found, for example, on the roof of the temple of Khonsu in Karnak, where many such examples were left by the lower clergy of the temple. ${ }^{26}$ In contrast to their more elevated colleagues, these priests could not afford temple statues similar to those that have been found in large quantities in the "Karnak Cachette". However, by inscribing their name, title, and/or footprints on the temple

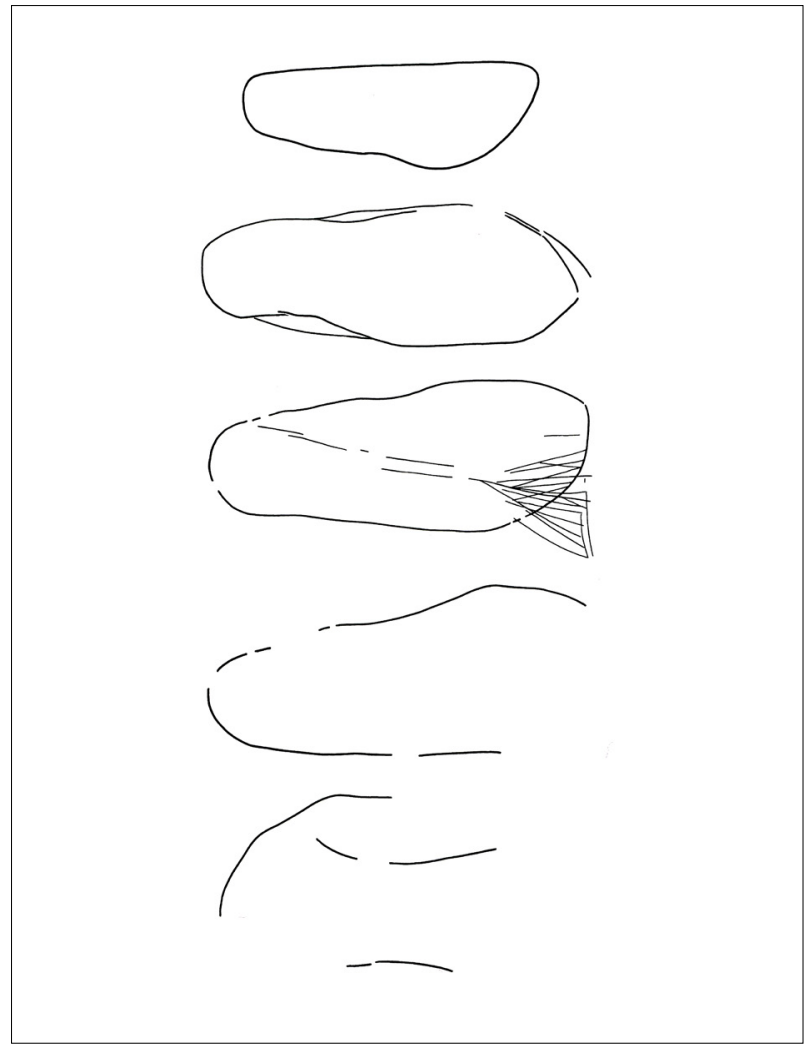

Fig. 1: Incised footprints on the pavement of the tomb of Maya and Meryt. Dimensions: unknown. From Martin, Tomb of Maya and Meryt, I, 2012, pl. 61.30. Image courtesy of the Egypt Exploration Society/Rijksmuseum van Oudheden, Leiden.

roof, these priests too would remain forever in the presence of "their" god, as some texts accompanying some of the feet explicitly state (Fig. 3). ${ }^{27}$ The graffiti of feet or sandals in the Saqqara necropolis were presumably similarly intended to place the graffitist into the permanent, sacred space of the tomb, and bore the hope that through these incised figures the funerary gods and/or the deceased could be reached. Because they represent the desire for an interaction between the devout and divine these graffiti can be considered the product of a devotional act. ${ }^{28}$ To fully grasp the nature of these devotional graffiti, it is necessary to consider their appropriation of the sacred context of the temple or tomb. The latter functioned as "liminal zones" where a dialogue between the devout and the divine or the living and the dead could be established..$^{29}$ It may be significant too in this respect that many devotional graffiti were carved into the sacred world of the temple of tomb, becoming one with it. ${ }^{30}$ The very permanence of incised figures may also have been a mark of their potency. By carving the inscription the graffitist produced an image 


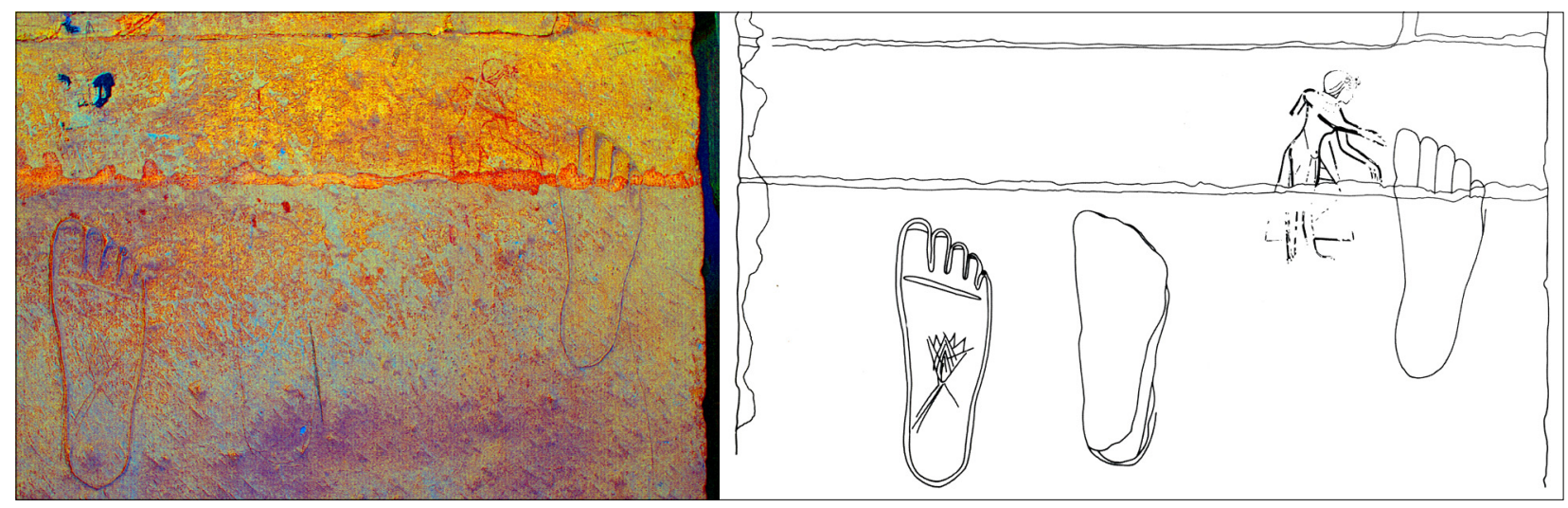

Fig. 2: Incised footprints on a statue niche in the tomb of Horemheb. Dimensions: each foot c. 25 × $9.5 \mathrm{~cm}$. Drawing from Martin, Memphite Tomb of Horemheb, I, 1989, pl. 149. Image courtesy of the Egypt Exploration Society/Rijksmuseum van Oudheden, Leiden. Photograph by Nico Staring, colours digitally enhanced using DStretch.

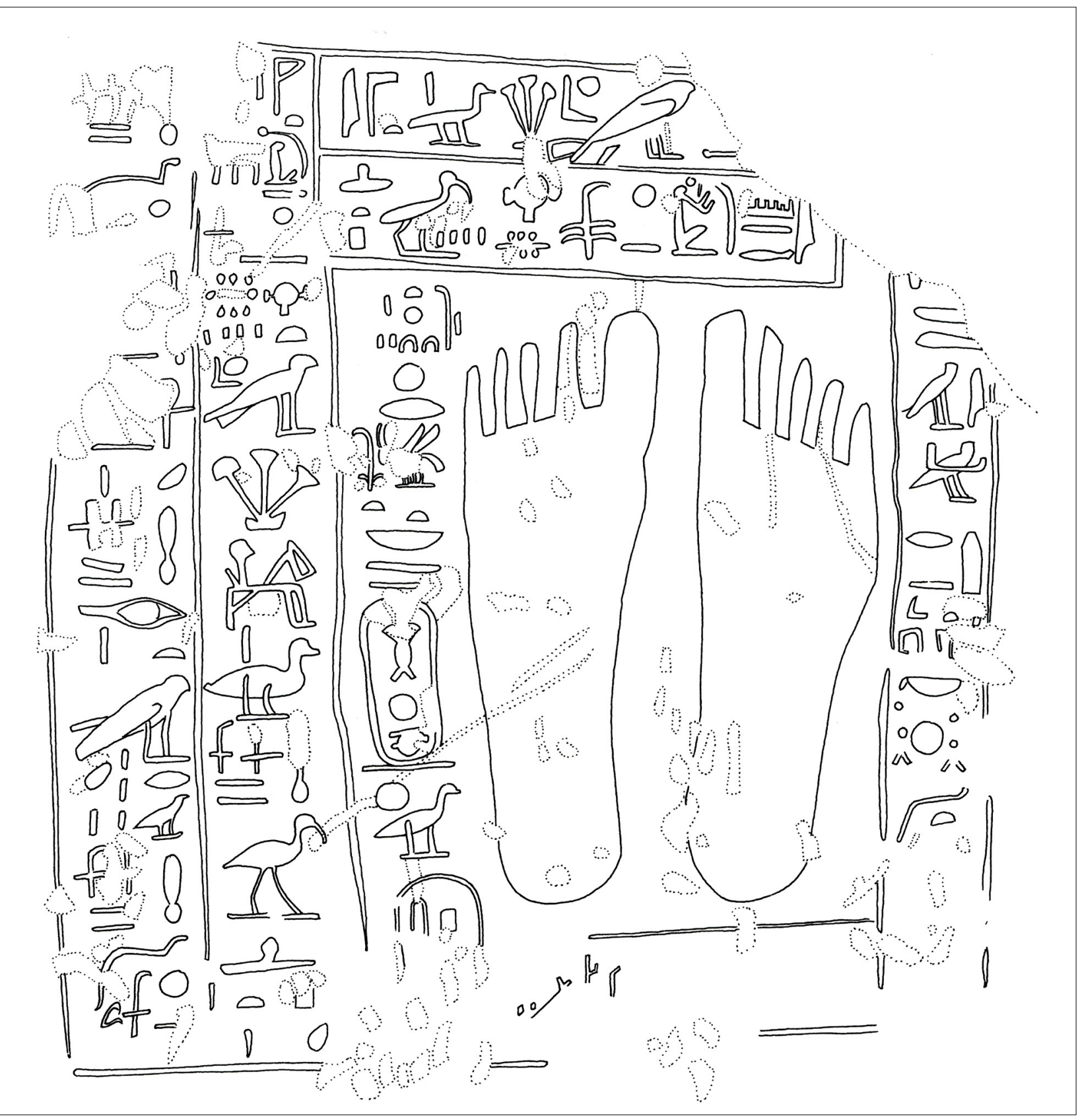

Fig. 3: Incised footprint on the roof of the temple of Khonsu at Karnak, dating to the Twenty-sixth Dynasty. Dimensions: 41 $x 39 \mathrm{~cm}$; length of footprints $24 \mathrm{~cm}$. The accompanying text states that the graffito is intended to make the name of the graffitist "endure" (imi $m n r n=i$ ) in the temple of Khonsu for ever and ever. From Jacquet-Gordon, Graffiti on the Temple Roof, 2003, pl. 106.275. Image courtesy of the Oriental Institute of the University of Chicago. 


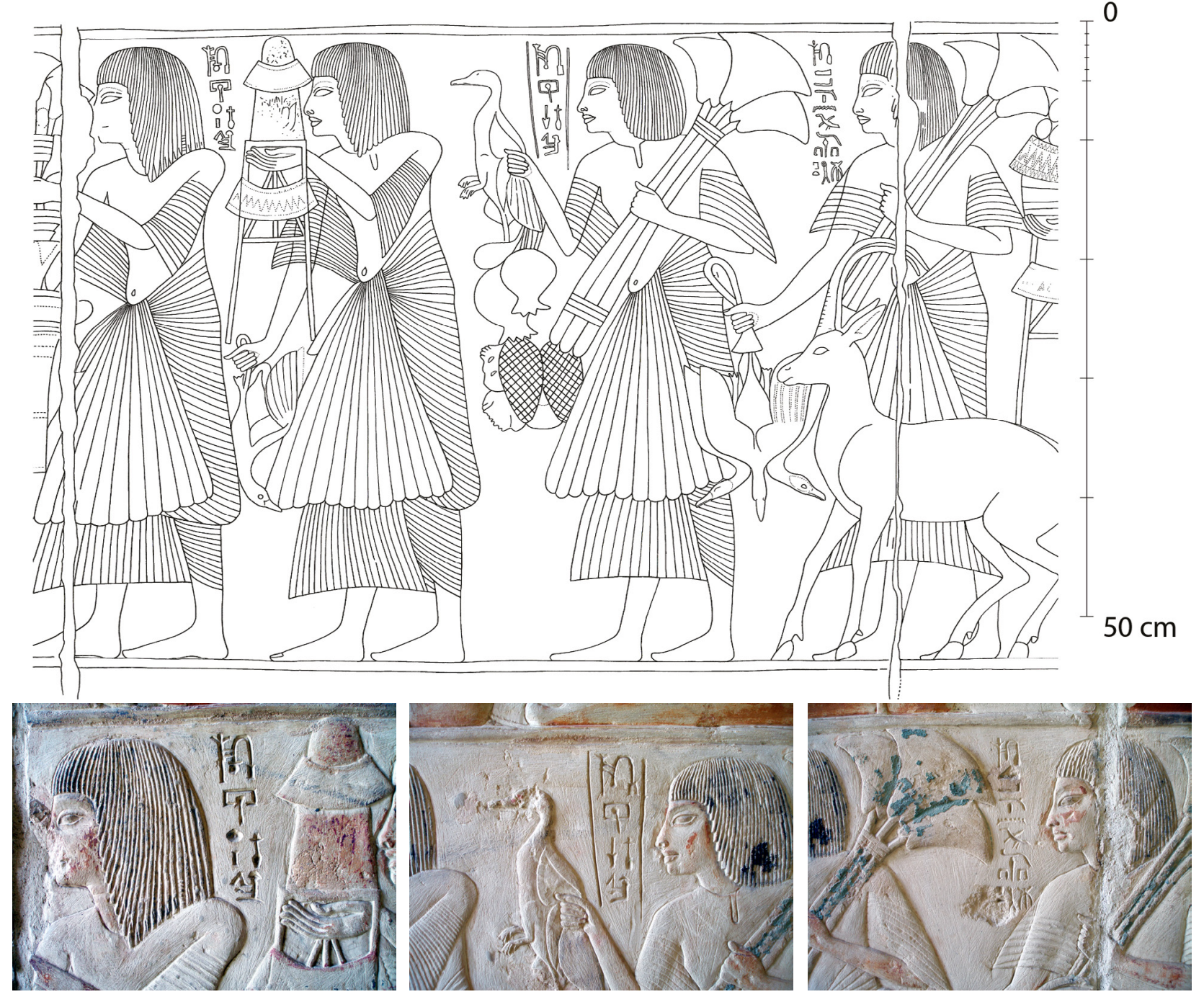

Fig. 4: Graffiti of personal names and titles carved next to figures belonging to the official tomb decoration in the pylon entrance of the tomb of Maya and Meryt. Drawing from Martin, Tomb of Maya and Meryt, I, 2012, pl. 12. Image courtesy of the Egypt Exploration Society/Rijksmuseum van Oudheden, Leiden. Photographs by Nico Staring.

that was much more durable than a painted message, and so ensured that his or her appeal would endure as long as the tomb or temple itself.

Other examples of devotional graffiti exist in the Saqqara area, for example in the pylon entrance of the tomb of Maya and Meryt ${ }^{31}$ and the inner courtyard of the tomb of Tia and Tia, ${ }^{32}$ where graffiti of personal names and titles were carved next to figures of offering-bearers belonging to the official tomb decoration (Figs. 4-5).

In the case of the tomb of Maya and Meryt the carved titles are all connected with the Treasury, of which Maya was the overseer, while in the tomb of Tia and Tia the graffitists consistently identify themselves as "servants". Therefore, the clear suggestion must be that by naming the figures in the tombs, Maya's and Tia's subordinates were marking their perpet- ual presence in their patrons' following in a manner comparable to the plantae pedis. Because of the graffitists' close relationship with the deceased, it is certainly possible that these inscriptions were envisaged as very direct and personal appeals and may have involved human sentiments of direct involvement, admiration, and concern. ${ }^{33}$ Perhaps leaving such graffiti was part of a cathartic experience that enabled healing for those who took solace in the belief that these inscriptions afforded a continued contact, or even existence, with the deceased. ${ }^{34}$ Their purpose may also have been to affirm and reinforce Maya's and Tia's status in the underworld, ensuring that the group and its hierarchy would continue in the hereafter. It is even possible that piety and self-interest were tangled and the graffitists wished to share in the wealth of their powerful overseers 


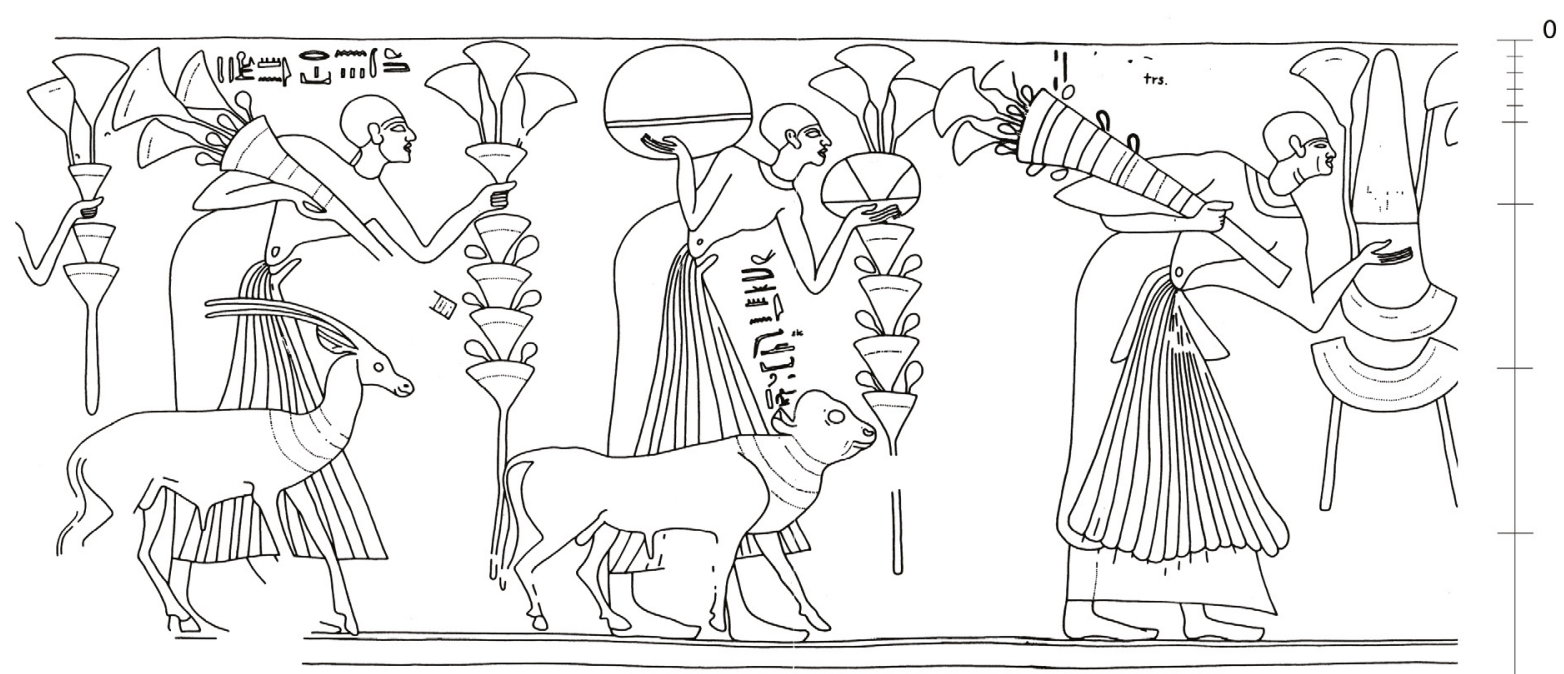

$40 \mathrm{~cm}$

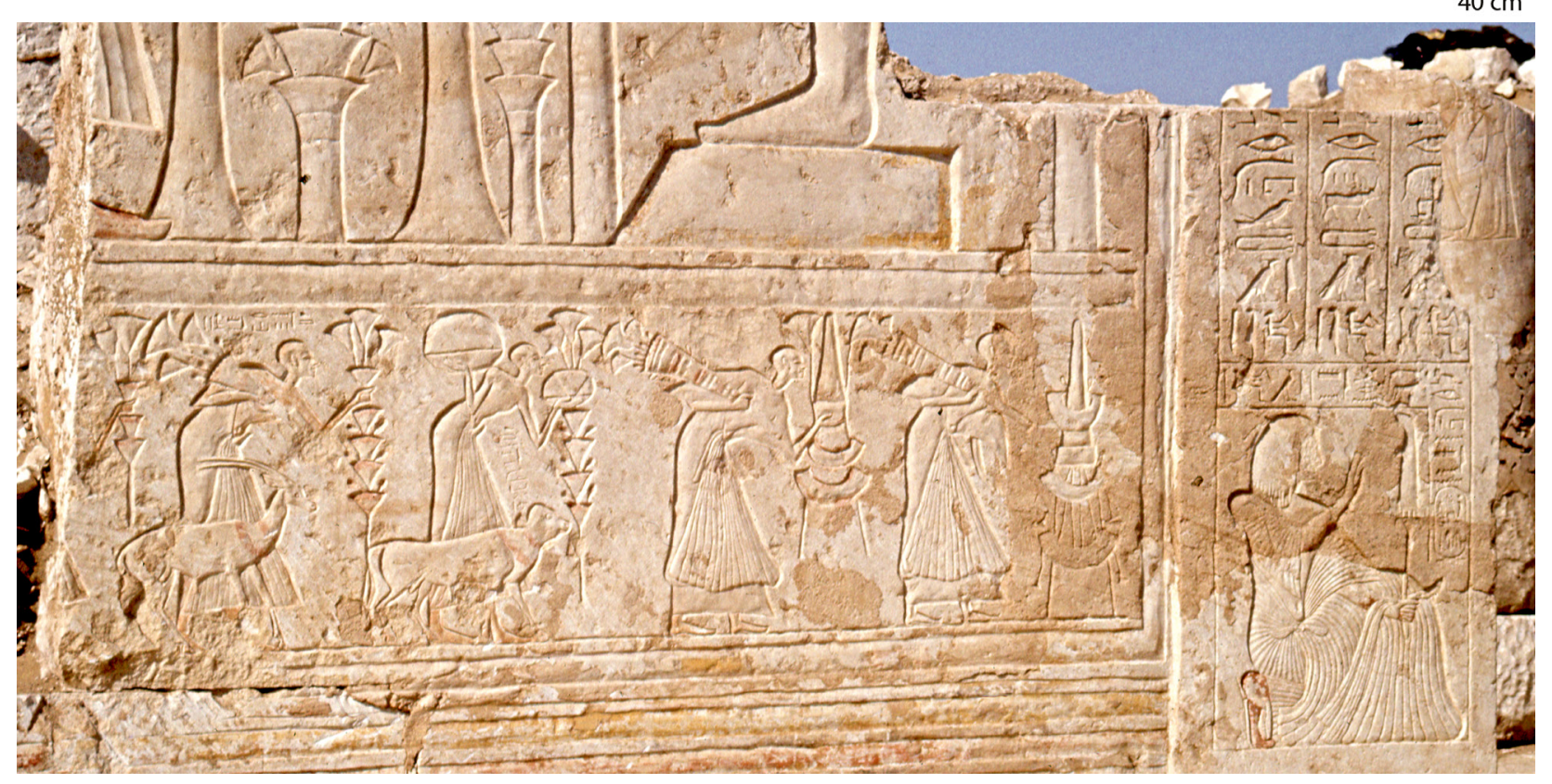

Fig. 5: Graffiti of personal names and titles carved next to figures belonging to the official tomb decoration in the inner courtyard of the tomb of Tia and Tia. Drawing from Martin, Tomb of Tia and Tia, 1997, pl. 37. Image courtesy of the Egypt Exploration Society/Rijksmuseum van Oudheden, Leiden. Photograph courtesy of the Rijksmuseum van Oudheden, Leiden.

by associating themselves with figures in the tomb decoration, which would allow them to partake of any offerings made in the tomb and benefit from the magical efficacy of the tomb's representations. ${ }^{35}$

While allowing for some ambiguity, it is possible that other graffiti, that were less directly or even unassociated with the official tomb decoration, should also be interpreted as meaningful, devotional messages. This may apply, for example, to signatures or short texts indicating names and titles. On the south wall of subterranean room $\mathrm{K}$ in the tomb of Maya and Meryt there are three hieratic dipinti in black pigment that were written upside-down and plastered over while the pigment was still wet (Fig. 6). ${ }^{36}$ Two of the dipinti are names (Smn[t3.wy?] and $H^{c} y$ ) and one may represent a cartouche.

The practice of writing graffiti upside-down and subsequently concealing them has a striking parallel in medieval churches, where names or abbreviations of names were sometimes incised at locations that were hidden from view, for example written upside-down high on a column or plastered over. ${ }^{37}$ As a result, such graffiti could not be seen or read by ordinary people. Instead, they were purportedly aimed at an eternal audience, in this case God, who could read the graffiti from above. ${ }^{38}$ It is tempting to interpret the plastered-over graffiti in Maya's tomb in a similar fashion. Perhaps they were intended to be "read" by the deceased, the deities depicted in the decoration of the subterranean parts of the tomb, 


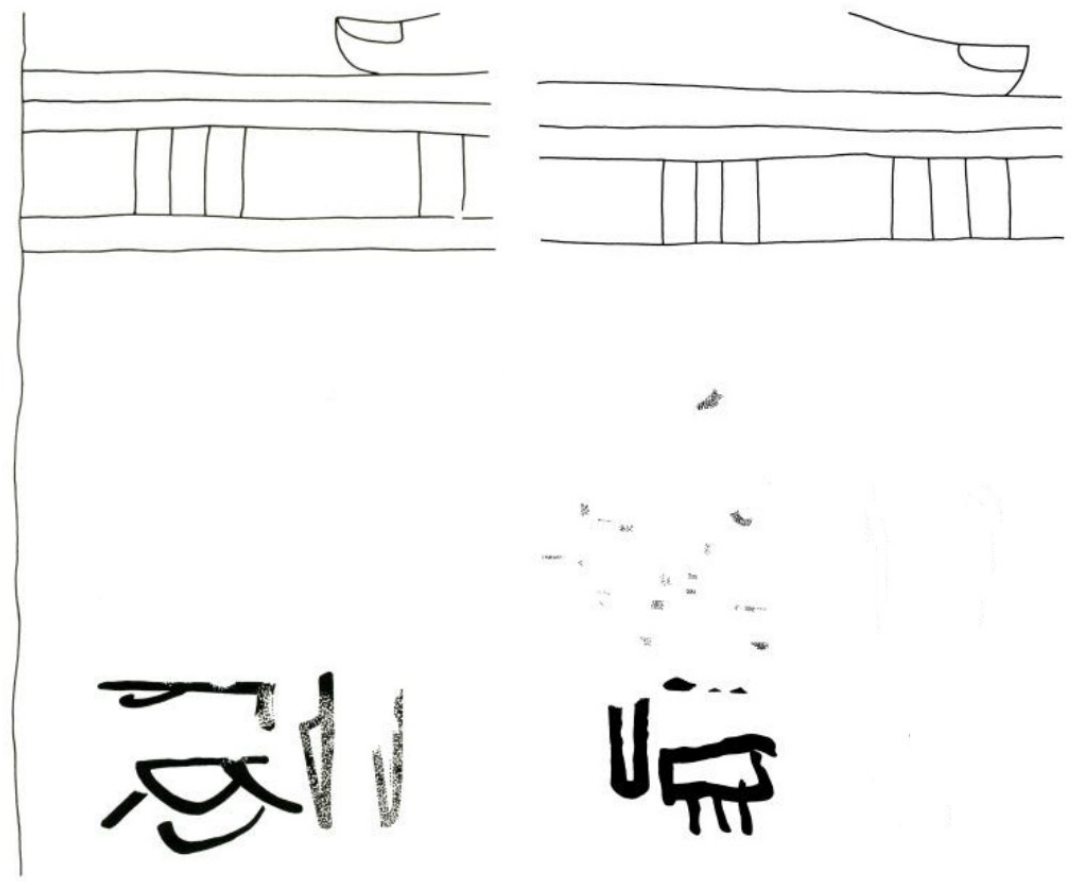

Fig. 6: Two hieratic dipinti of personal names in subterranean room $\mathrm{K}$ in the tomb of Maya and Meryt. The dipinti were written upside-down and plastered over while the pigment was still wet. Dimensions: $18.8 \times 7 \mathrm{~cm} ; 6.8 \times 12 \mathrm{~cm}$. From Martin, Tomb of Maya and Meryt, I, 2012, pl. 59.2-3. Image courtesy of the Egypt Exploration Society/Rijksmuseum van Oudheden, Leiden.
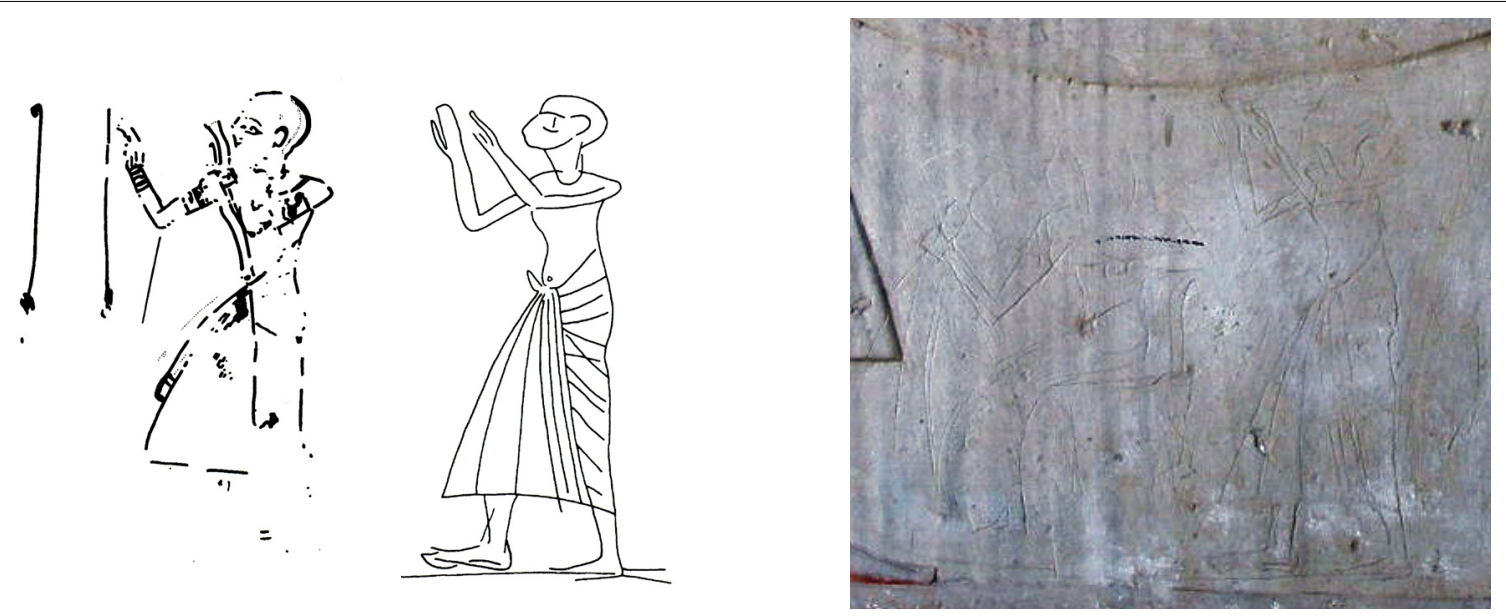

Fig. 7: Graffiti of human figures in poses of adoration in the tombs of Tia and Tia (above, left) and Maya and Meryt (above, right, and below). Dimensions: Tia, 23.2 x $16 \mathrm{~cm}$; Maya, 17.4 x $8.1 \mathrm{~cm}$. From Martin, Tomb of Tia and Tia, 1997, pl. 93.324, and Martin, Tomb of Maya and Meryt, I, 2012, pl. 61.27. Image courtesy of the Egypt Exploration Society/ Rijksmuseum van Oudheden, Leiden. Photograph by Nico Staring.

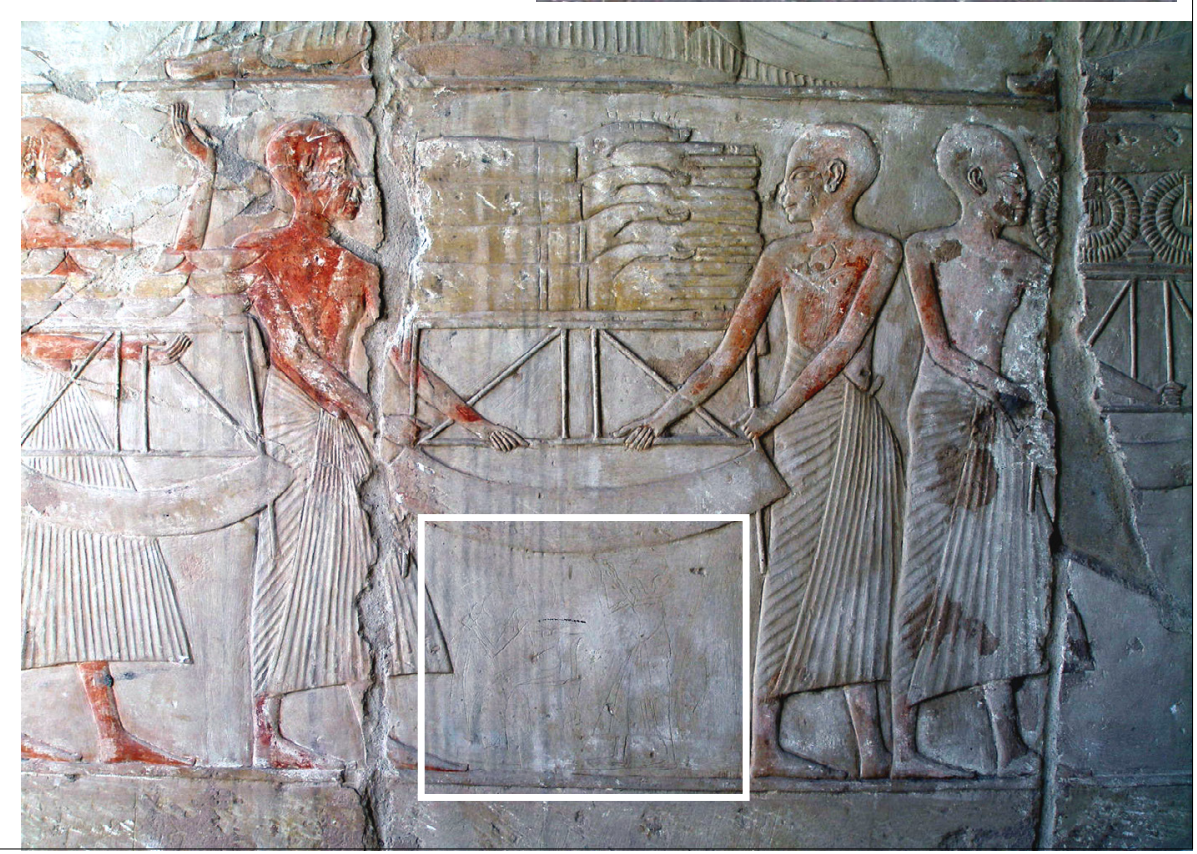


or both. However, it cannot be excluded that these graffiti had a more utilitarian function and were connected to the construction of the tomb.

There are indications that figural graffiti could also be used to convey devotional messages. For example, in a scene from the tomb of Djehutymes (Bub. I.16) in the Abwab el-Qotat/Bubasteion area, diminutive figures were added to an offering scene in a different style, possibly enlarging family numbers, while in the nearby tomb of Ptahmose (Bub. II.x) a small naked boy and a larger bending figure were added in a "scribal" hand to an offering scene. These graffiti bear tangible witness to a physical interaction with their sacred surroundings and seem to symbolically mark the permanent presence of the persons depicted in the inscriptions, forging a material and immaterial future where desires for posthumous interaction were solidified. ${ }^{39}$ It is important to acknowledge here that, because of the inherent magic of pictures, these graffiti would have been directly associated with an individual in much the same way as an inscribed signature would have been, setting the need for literacy aside..$^{40}$ As such, they may represent a directly personal interaction between the individual and the deceased that did not require the mediations of a trained priest or scribe.

Other types of human figures were possibly also intended as expressions of devotional interaction.
Graffiti of figures in poses of adoration, ${ }^{41}$ in particular, may be considered as prayers cast in pictorial form that were set in stone for the enduring benefit of the deceased (Fig. 7). ${ }^{42}$

Two graffiti in the tomb of Maya and Meryt depicting women with unguent cones on their heads are also noteworthy in this context, both for their location, medium, and skill of execution (Fig. 8). ${ }^{43}$

These graffiti are located in Burial Chamber $O$ in the subterranean part of the tomb at a depth of almost $22 \mathrm{~m}$ below the surface, and were executed in black pigment by a skilled (perhaps professional) draughtsman, who was careful to respect the existing tomb decoration. In both cases, the graffiti are unobtrusively placed below depictions of Meryt - in two separate scenes - clearly indicating that defacement of the monument was not the intention of the graffitist. Rather, their systematic placement appears to associate the graffiti with the recurring figure of Meryt. Perhaps they depict one or more of Meryt's family members, and were intended, albeit in visual form only, to establish an intimate link with the body of Meryt, which was interred in this very room. ${ }^{44}$ The supposition that these graffiti were not momentary ideas or inspirations, but well thought-out messages with symbolic efficacy is also hinted at by the medium in which they are executed. If the graffiti were applied underground, the draughtsman would have
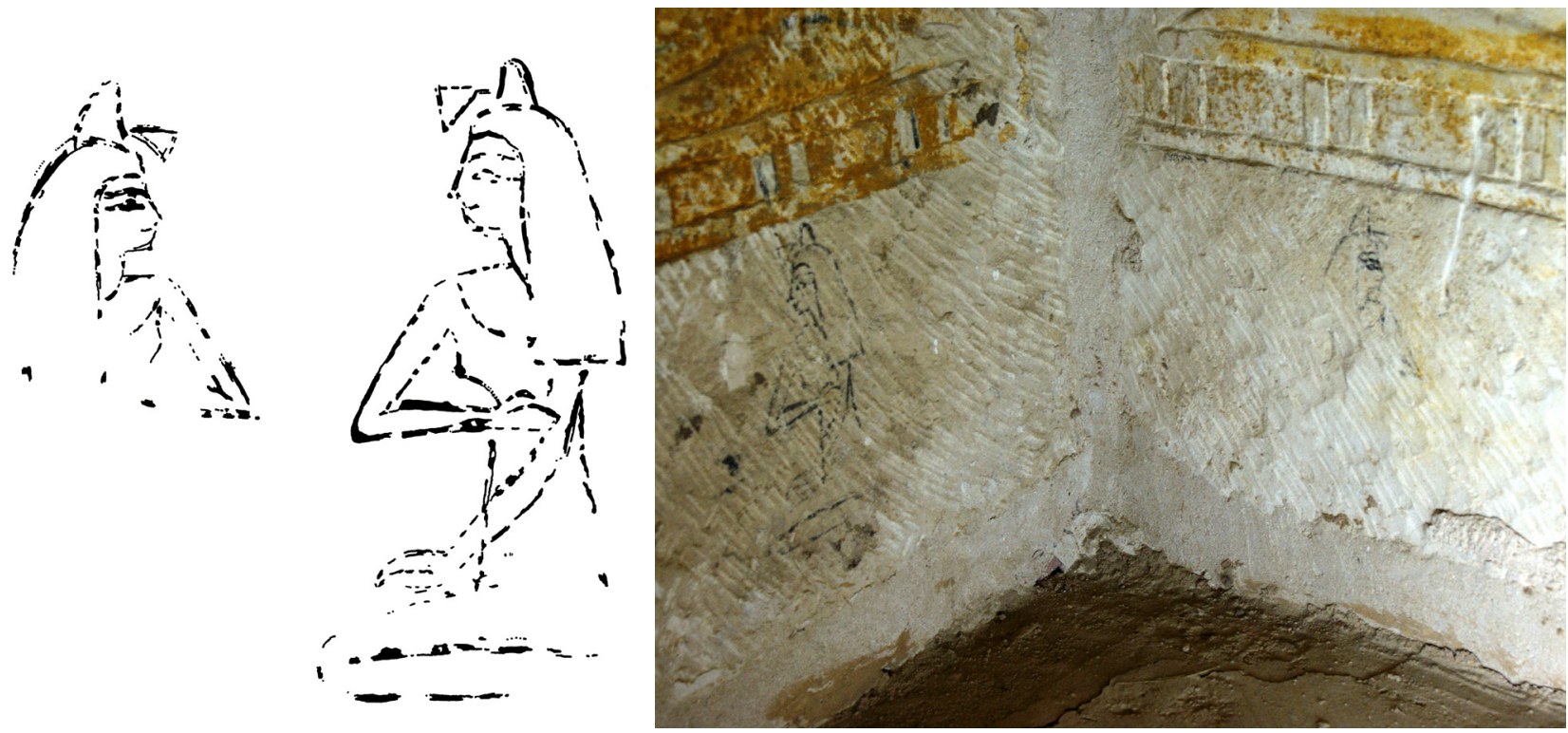

Fig. 8: Two graffiti in Burial Chamber $O$ of the tomb of Maya and Meryt depicting women with unguent cones on their heads. In both cases, the graffiti are unobtrusively placed below depictions of Meryt in two separate scenes. Dimensions: $10.5 \times 8 \mathrm{~cm}$; 19.8 × $9.3 \mathrm{~cm}$. Drawing from Martin, Tomb of Maya and Meryt, I, 2012, pl. 60.14-15. Image courtesy of the Egypt Exploration Society/Rijksmuseum van Oudheden, Leiden. Photograph by Nico Staring. 
gone through the effort of carrying a scribe's outfit down two deep shafts and would also have taken a light source of some sort. On the other hand, if the graffiti were applied prior to the placement of the blocks in the subterranean part of the tomb, they can still be interpreted as devotional messages as in this case the graffitist may have anticipated the placement of the blocks in the burial chamber. ${ }^{45}$ In either case, it appears that the placement of these graffiti deep underground was deliberate, and so their location must have been deemed significant.

It certainly seems possible that some of the devotional graffiti discussed here were left by the illiterate, more humble section(s) of the Egyptian population. That the Saqqara necropolis was accessible to different levels of Egyptian society, at least during the later New Kingdom, seems clear from the presence of secondary, modest burials in or adjacent to many of the monumental tombs. ${ }^{46}$ Indeed, there may have existed a degree of conceptual equivalence across the domains of leaving graffiti in tombs and burying the deceased in simple pit-burials inside or near the tombs of the highest elite. These burials can perhaps also be interpreted as premeditated devotional acts aimed at posthumous interaction with the tomb owner, particularly in the context of the tomb of Horemheb, which became the focus of a cult. At the same time, they may have aimed at posthumous upward mobility or attempted to benefit from the magical efficacy of the tomb's representations.

\subsection{Graffiti as a ritual act}

In addition to devotional motivations, there are indications that point to a ritual dimension for certain groups of graffiti. ${ }^{47}$ Repetition and standardisation are commonly recognised features of ritual. ${ }^{48} \mathrm{As}$ already noted by Helck, ${ }^{49}$ certain types of written graffiti follow firmly established formulae and are extremely repetitive in their content. ${ }^{50}$ Fischer-Elfert and Kahl therefore suggested that writing visitors' graffiti was a topic taught at "school" ${ }^{51}$ The subgroup of antiquarian or descriptive graffiti, which praise specific monuments and their owners, may particularly be considered a ritualised reaction to what is commonly called the "Address to the Living". ${ }^{52}$ In this address, which is not only inscribed on tomb walls but also on stelae and statues, tomb-owners

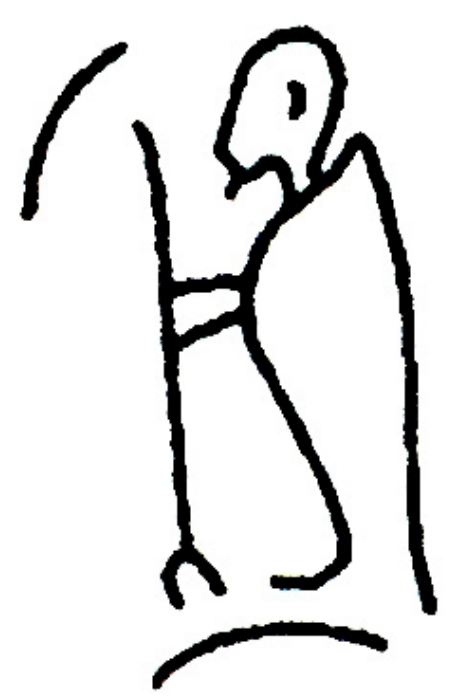

Fig. 9: Graffito of the god Ptah in the inner courtyard of Tia and Tia, scratched on the flat upper surface of the unfinished triad statue. Dimensions: $4 \times 2.5 \mathrm{~cm}$. From Martin, Tomb of Tia and Tia, 1997, pl. 93.320. Image courtesy of the Egypt Exploration Society/Rijksmuseum van Oudheden, Leiden.

ask passers-by or visitors for offerings or a prayer. ${ }^{53}$ In ancient Egypt the survival of an individual was amongst other factors linked to the memory of his or her name, which was revitalised each time it was pronounced or even read. Thus, to keep the name of a person alive through a graffito, by identifying a certain monument with the name of its owner, can be interpreted as a benevolent, ritualistic act.

Textual graffiti may not have been unique in their capacity to materialise ritual acts. Certain types of representations, especially those of an intrinsically religious nature, such as gods (Fig. 9), point towards a ritual dimension for some of the figural graffiti as well. $^{54}$

Most striking in this respect is a group of nine graffiti of standing jackals depicted atop standards in the tomb of Ptahemwia (Fig. 10). The standards are often accompanied by a bulge that is otherwise commonly identified as a uraeus. ${ }^{55}$ Although identifying labels are absent, it is reasonable to assume on the basis of analogous pictorial evidence that these images represent either Anubis or Wepwawet. Both these canine gods are intimately linked with the funerary cult, and it should therefore not be a matter of surprise if several ritual acts involving them were to be found amongst the graffiti in a tomb. Two aspects of these figures stand out in particular. First, differences in style and technique - most figures being scratched, but some being incised - strongly suggest 

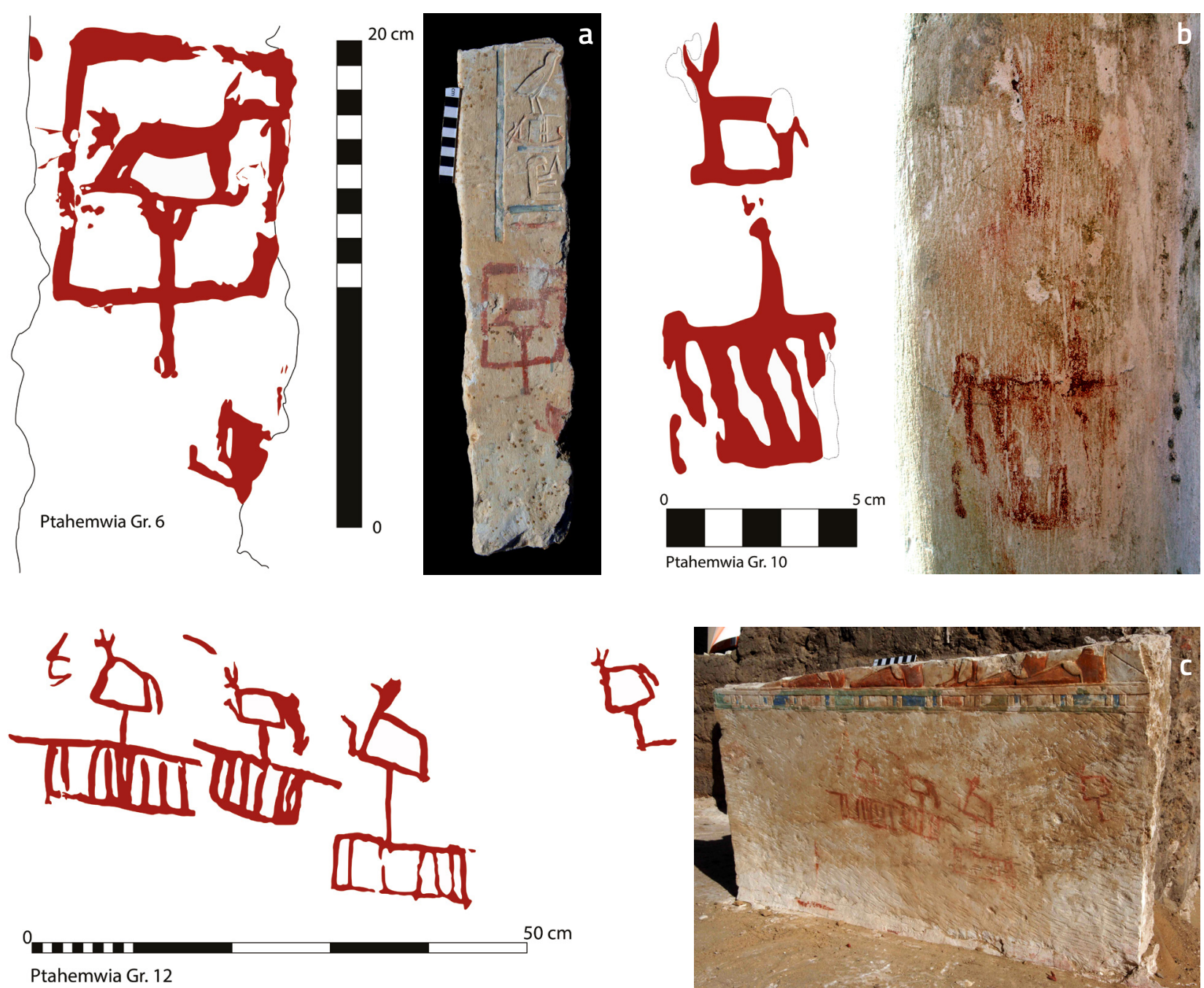

$50 \mathrm{~cm}$

Ptahemwia Gr. 12

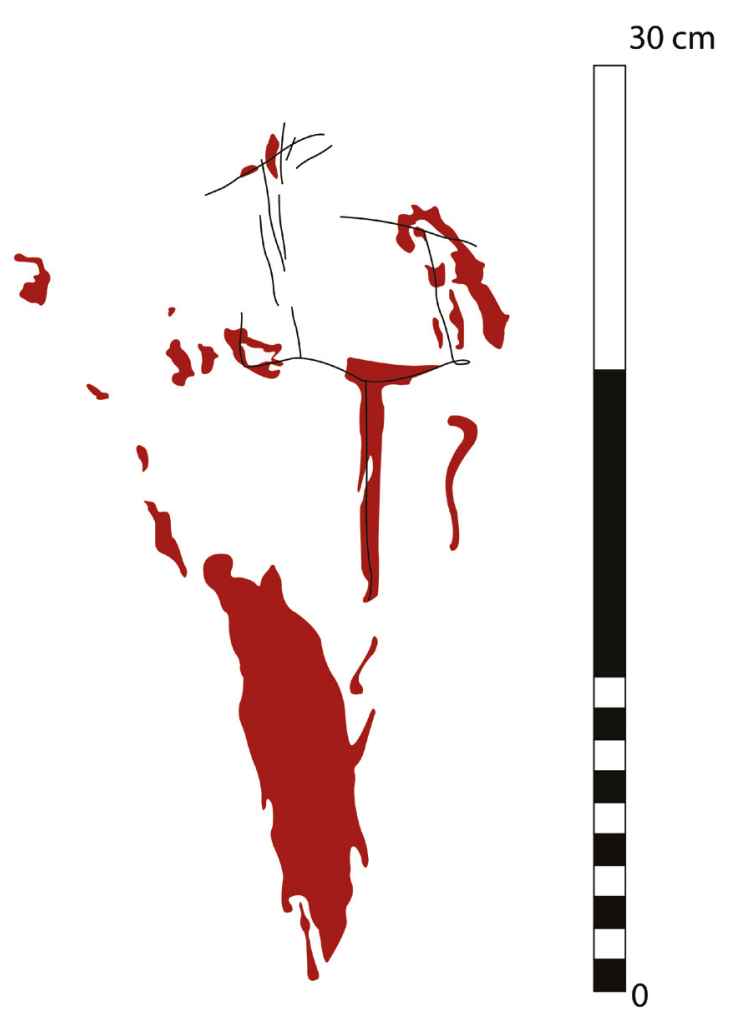

Ptahemwia Gr. 27

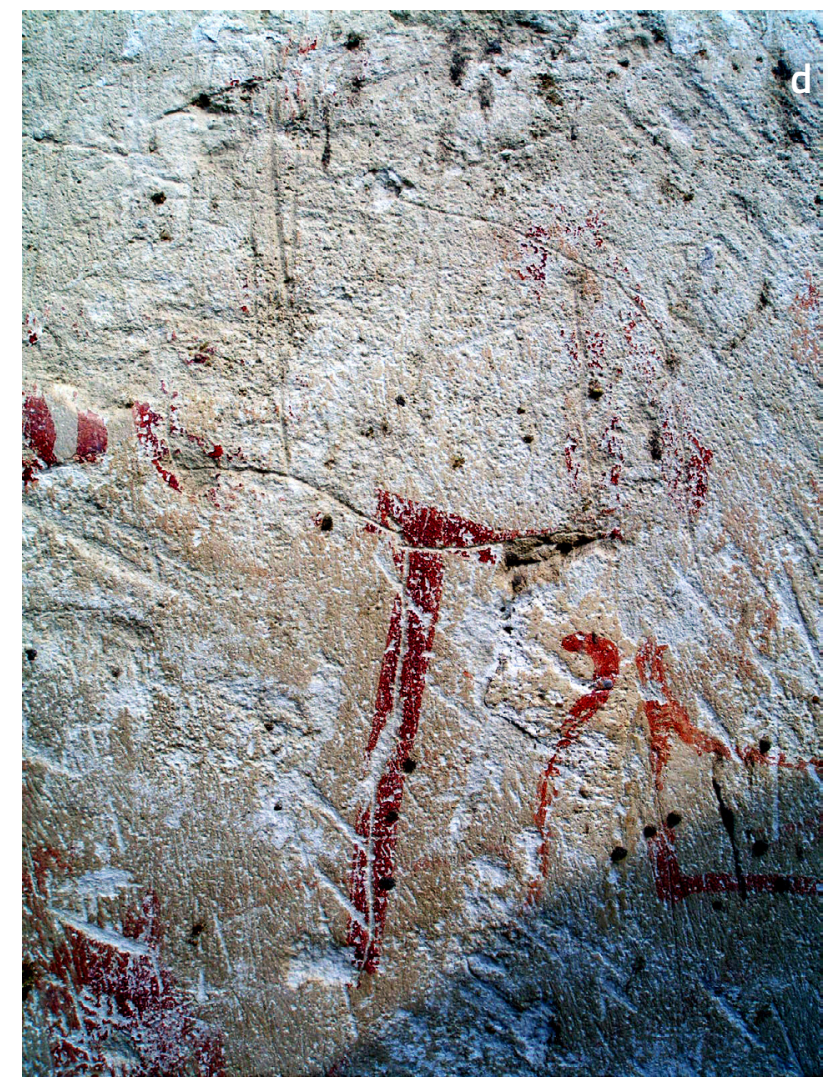

Fig. 10: Graffiti of standing jackals atop standards in the tomb of Ptahemwia. Drawings and photographs by the authors. Phtotograph 10a courtesy of the Rijksmuseum van Oudheden, Leiden. 
that the jackals were applied by different individuals, each with their own idiosyncratic modus operandi. Second, all jackals face west and are oriented towards the inner sanctum of Ptahemwia's central chapel. This distinct pattern suggests that the orientation towards the focus of the funerary cult was an important part of the graffiti's creation. The frequency and the recognisable system in which these graffiti occur suggest that they were purposeful messages with symbolic efficacy. This impression is enhanced by the medium in which most examples were executed. No less than eight out of nine specimens were originally painted in red ochre, implying that those responsible for their execution had to bring writing equipment to the tomb.

While it is difficult to establish the exact reasons for creating these graffiti, one may perhaps assume them to be a means of communication with the divine, intended to secure divine protection for the graffitist, the tomb-owner(s), or both. ${ }^{56}$ If so, these graffiti were expressions of awe and piety intended to propitiate the benevolent aspects of mortuary deities to obtain safe conduct in their domain. Anubis' role as guardian of the necropolis and Wepwawet's capacity of psychopompos would certainly fit such an interpretation. Representations of Anubis sitting atop a shrine and protecting the deceased are very common from the Middle Kingdom onwards, and occur on a great variety of objects as well as in tomb paintings. ${ }^{57}$ While jackal graffiti have not been found elsewhere in the Leiden-Turin concession area, they appear to have been commonplace throughout the Nile Valley. For example, a jackal head graffito is incised in the tomb of Aper-El at the Abwab el-Qotat/ Bubasteion. ${ }^{58}$ Parallels are also present in tomb N13.1 in Asyut, where three representations of dogs/ jackals have been found. One of these may have been represented on a divine stand..$^{59}$ Even more striking are the graffiti of standing jackals incised on a Thirteenth Dynasty stela from Abydos that is now kept in
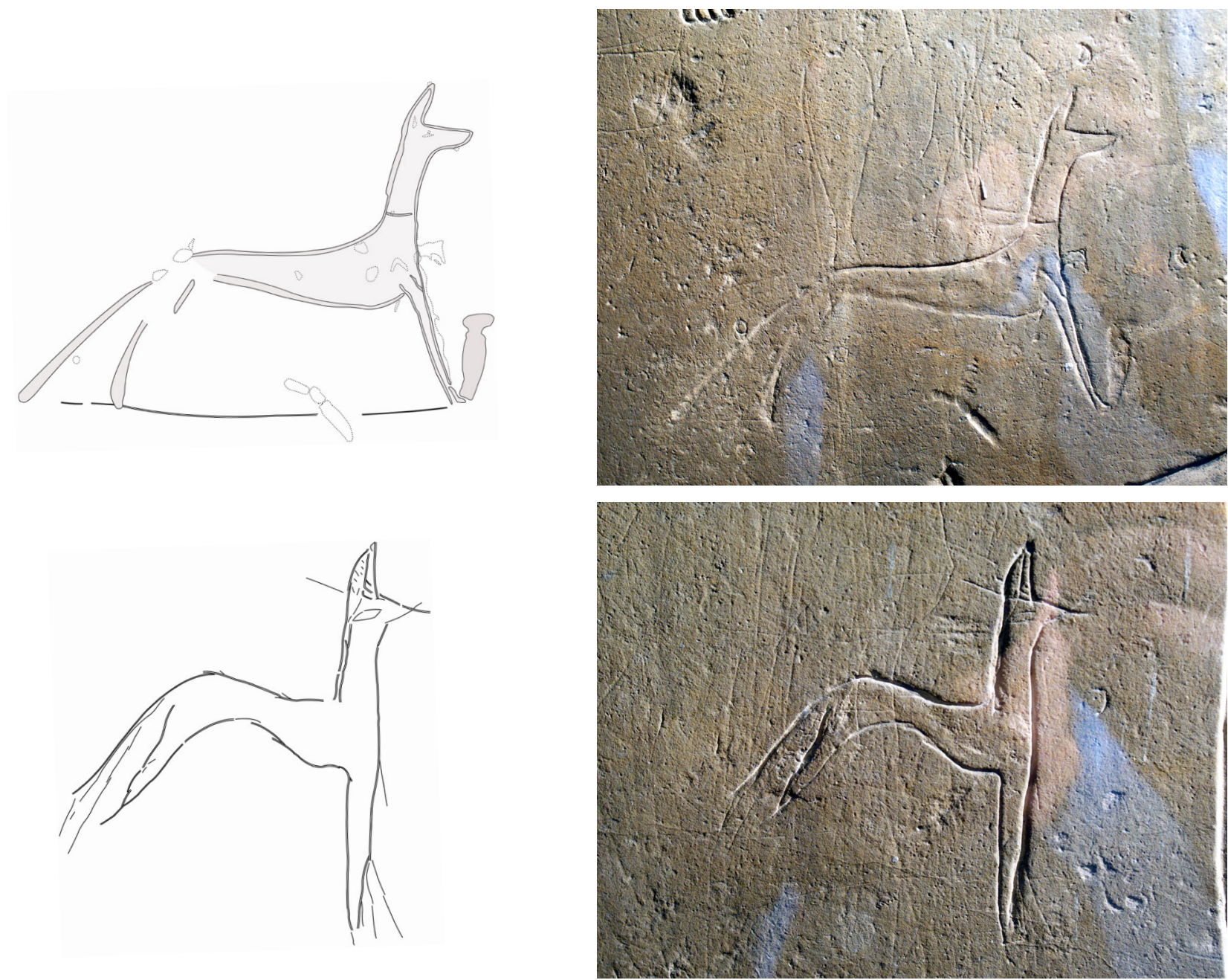

Fig. 11: Graffiti of standing jackals incised on a Thirteenth Dynasty stela from Abydos (Louvre C8).

Dimensions: c. $10.9 \times 16.4$ cm (above); c. $9.9 \times 8.9$ cm (below). Drawings and photographs by Nico Staring. 

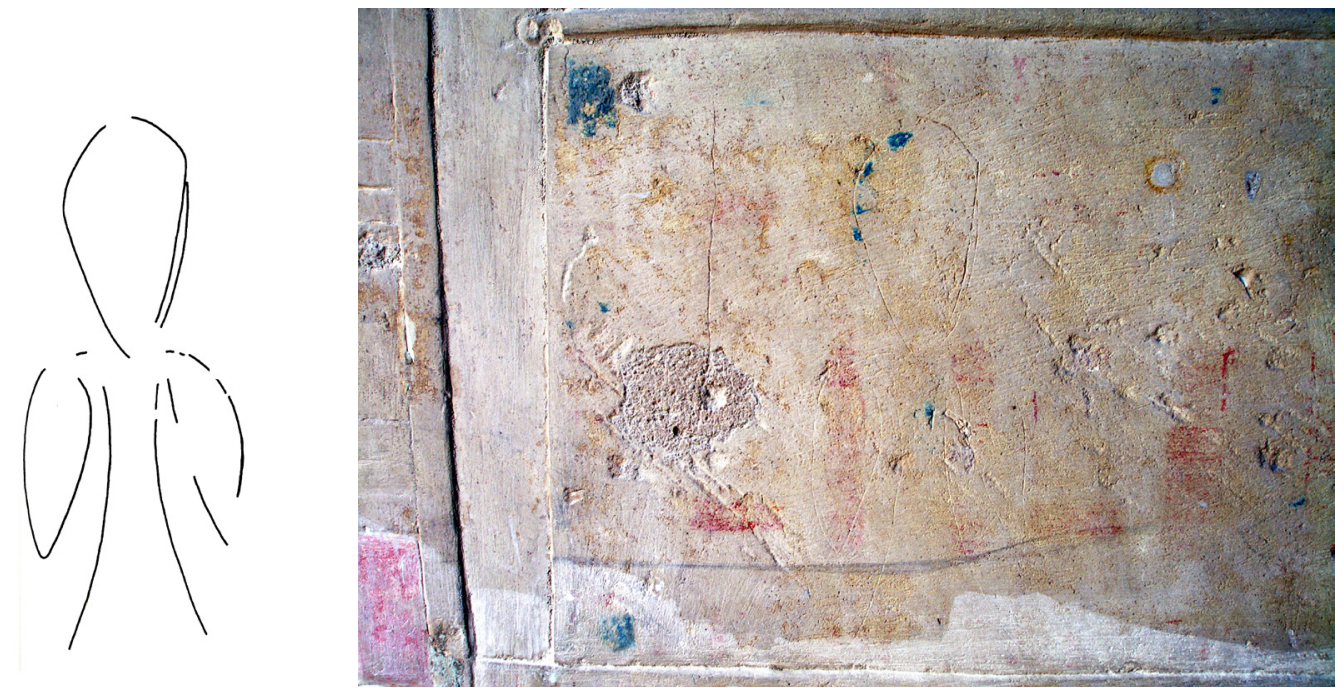

Fig. 12: Graffito of a tyet knot in the tomb of Maya and Meryt. Dimensions: $15.6 \times 7.2 \mathrm{~cm}$. From Martin, Tomb of Maya and Meryt, I, 2012, pl. 59.1. Image courtesy of the Egypt Exploration Society/Rijksmuseum van Oudheden, Leiden. Photo by N. Staring.
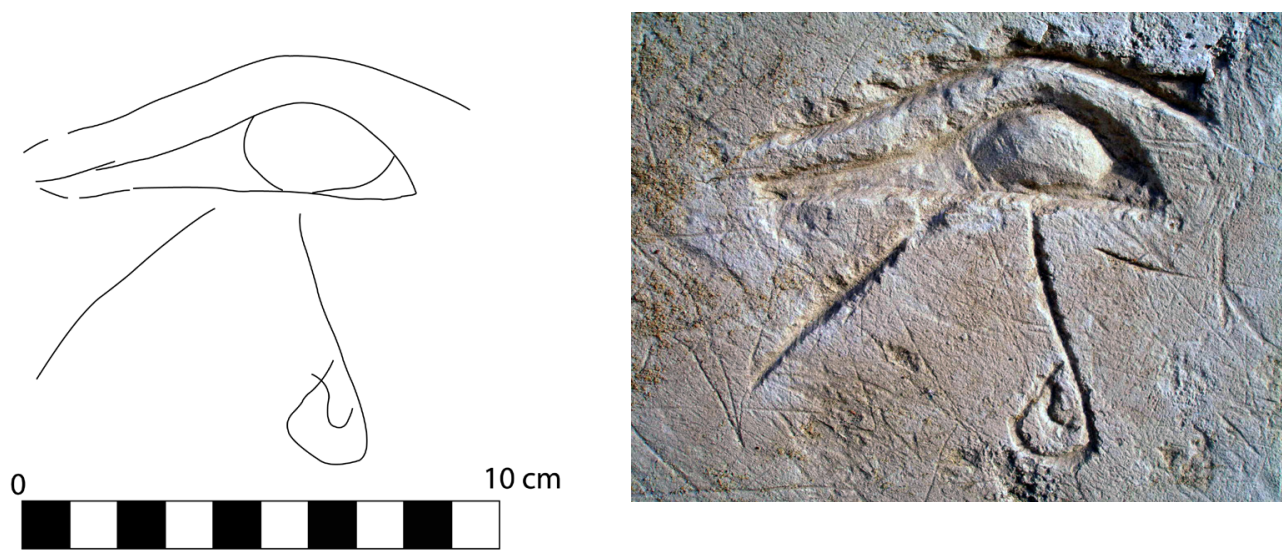

Ptahemwia Gr. 23

Fig. 13: Graffito of a wedjat eye in the tomb of Ptahemwia. Note that the graffitist made a mistake in the depiction of the markings around the falcon's eye, curling the "teardrop" below the eye instead of the marking to its left. Drawing and photograph by the authors.
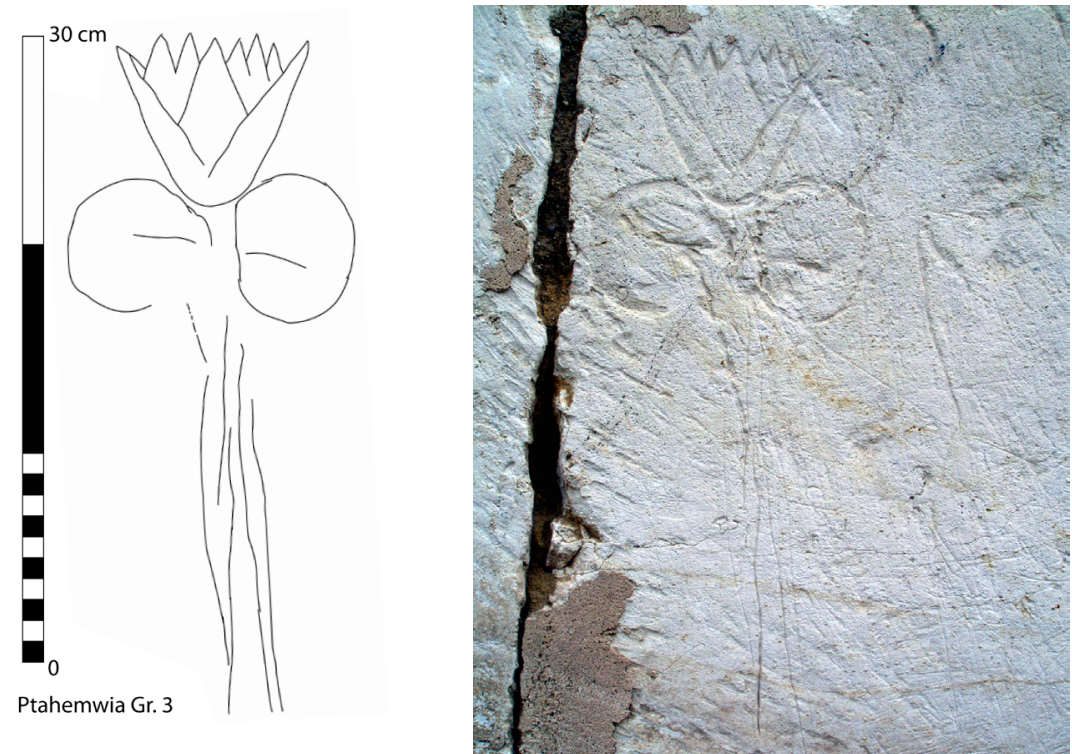

Fig. 14: Graffito of a lotus flower with 9 petals, 2 lotus flowers, and a shallowly scratched stem in the tomb of Ptahemwia. Drawing and photograph by the authors. 
the Louvre (Louvre C8) (Fig. 11). ${ }^{60}$ As with the graffiti in the tomb of Ptahemwia, these figures appear to have been executed by several individuals using different styles and techniques, and are all facing a representation of Min-Horus to whom the adorations on the stela are dedicated. ${ }^{61}$ Jackal graffiti thus seem to occur repeatedly, over prolonged periods and at widespread locations. The placement of these graffiti on tomb walls and stelae furthermore appears to follow a recognisable system in that they are oriented towards important foci of the funerary cult. As such, it is tempting to interpret them as standardised ritual acts, possibly reflecting folk practices and beliefs connected to the maintenance and protection of the deceased. The fact that each jackal graffito in the tomb of Ptahemwia respected previous inscriptions, and was in turn, respected, would also suggest that such practices were considered both appropriate and accepted forms of devotion. ${ }^{62}$ None of the jackal graffiti suffered defacement, despite being obvious to the casual observer due to the sharp contrast between the red pigment and the white limestone background.

Other figural graffiti such as those depicting tyet knots, wedjat eyes, or lotus flowers, may also have served an apotropaic purpose. A graffito of a tyet knot occurs in the tomb of Maya and Meryt, where it is incised into a painted tyet knot belonging to the official tomb decoration (Fig. 12). ${ }^{63}$

The tyet was closely associated with the goddess Isis and widely used as an amulet. According to Book of the Dead spell 156 it was considered a powerful charm for the protection of the deceased in the afterlife. ${ }^{64}$ The wedjat eye, which is depicted in a graffito in Ptahemwia's courtyard (Fig. 13), is perhaps the best known of all Egyptian protective symbols. ${ }^{65} \mathrm{Ac}-$ cording to one myth it represents the eye of Horus which was plucked out by the god Seth and later restored by the god Thoth, making it into a symbol of wholeness, good health, and regeneration. Others associate it with the eye of Ra, which functioned as a violent force that subdued the sun god's enemies. The wedjat may therefore be imbued with both the healing power of the "sound eye" of Horus and the protective power of the ferocious goddess who was the eye of Ra. ${ }^{66}$ With these properties, the wedjat was clearly a motif well-suited to benevolent, ritu- alistic expressions associated with the protection of the deceased. ${ }^{67}$ It features prominently in the decoration of New Kingdom tombs and also occurs on pyramidia, door lintels, and the lunette of stelae, often in combination with other protective symbols such as the shen ring and depictions of Anubis recumbent on a shrine.

Lotus flowers, likewise, had many positive symbolic connotations. All growing plants were inherently symbolic of new life, but because the blue lotus flower (Nymphaea caerulea) closes and sinks under water at night only to rise and open again at dawn, it had particularly strong connotations of creation and rebirth. ${ }^{68}$ Lotus images may also have evoked the image of the infant sun god, born from the primeval lotus, and thus symbolise the hope of rebirth. ${ }^{69}$ It are perhaps such associations that account for the presence of the two lotus graffiti in the tomb of Ptahemwia (Fig. 14), with further examples being attested in the tomb of Maya and Meryt, ${ }^{70}$ Horemheb,${ }^{71}$ and Ramose. ${ }^{72}$ The solar association of these graffiti is perhaps hinted at by their location. No less than 10 out of the 11 examples in the Leiden-Turin concession area have been inscribed on the entrance doorway or east wall of the first courtyard of the tomb, and are thus oriented towards the rising sun.

The group of ritual graffiti can possibly be extended by including certain groups of animal graffiti, most notably depictions of baboons and lions. Although the baboon (Fig. 15) was associated with several deities, in particular Thoth, the funeral context of the graffiti suggests that they here may represent Hapy, one of the Sons of Horus, who was concerned with the protection of the deceased. ${ }^{73}$ Brown quartzite statues attributed to this god were found at Amenhotep III's mortuary temple at Thebes, one of which bears witness to the protective nature of the god in the epithet "he who cuts off the face of him who cuts off your face". ${ }^{74}$ Alternatively, some of the baboon graffiti may depict Thoth, the patron god of scribes, in the guise of a baboon. Thoth's epithet "true scribe of the Ennead" denotes his mediating qualities in the divine world, and perhaps some graffitists were invoking this intermediary role when scratching Thoth's representations into the walls of tombs. ${ }^{75}$ Even if the proposed associations with Hapy or Thoth were incorrect, the baboon's ferocity would 

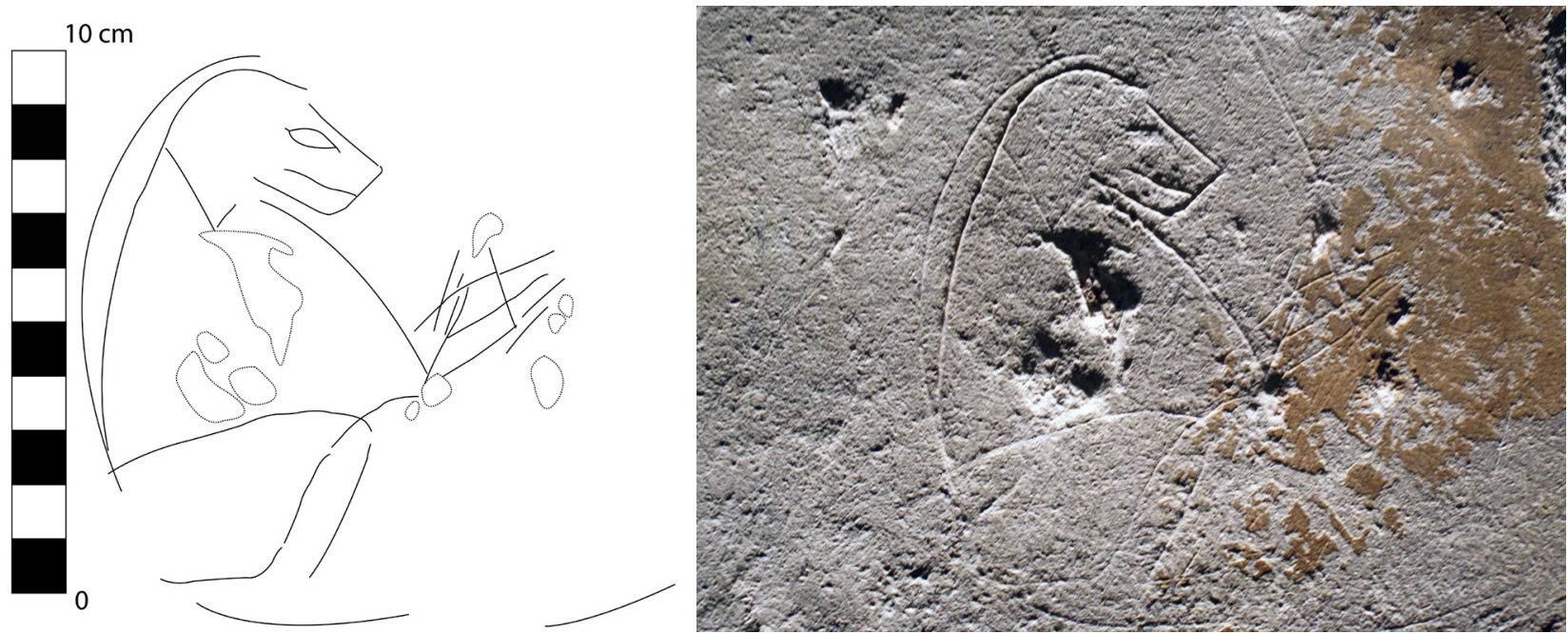

Ptahmose Leiden AP 51

Fig. 15: Graffito of a seated baboon on a pillar from the tomb of Ptahmose. Drawing and photograph by Nico Staring.

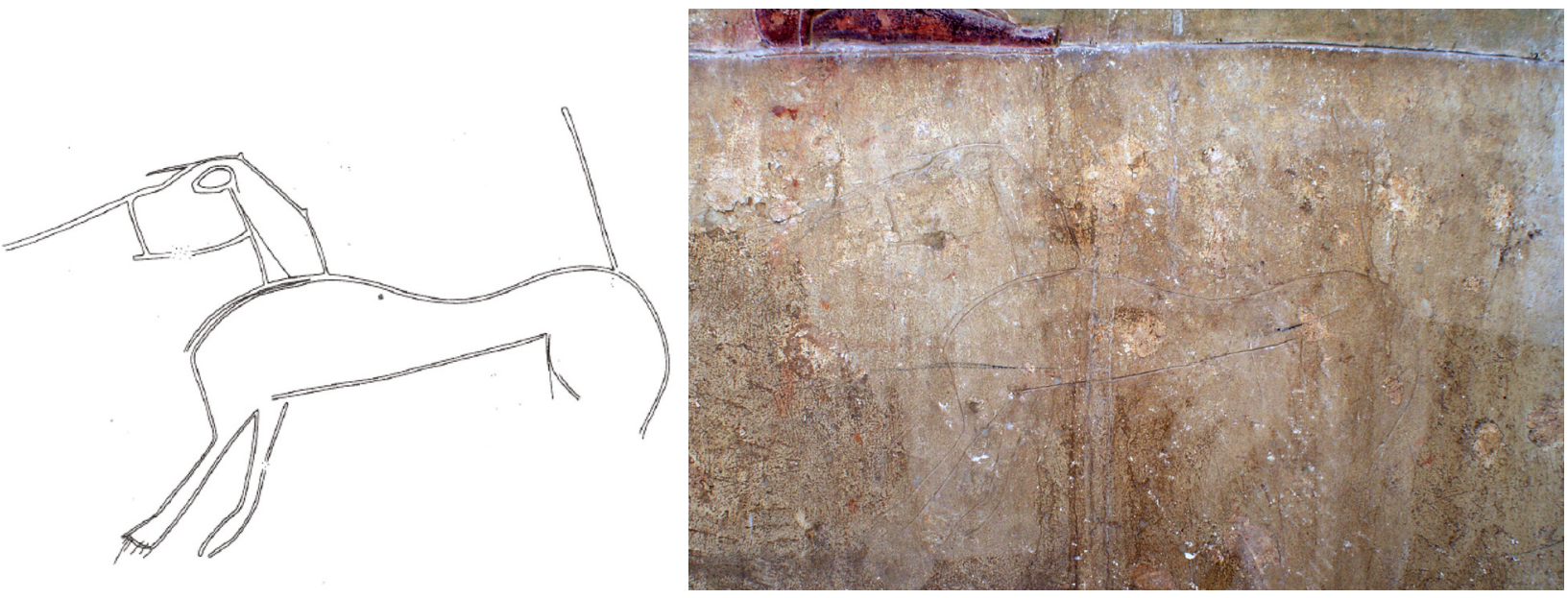

Fig. 16: Graffito of a lion in the tomb of Horemheb. Dimensions: $16.2 \times 25.2 \mathrm{~cm}$. From Martin, Memphite Tomb of Horemheb, I, 1989, pl. 147.15. Image courtesy of the Egypt Exploration Society/Rijksmuseum van Oudheden, Leiden. Photograph by Nico Staring.
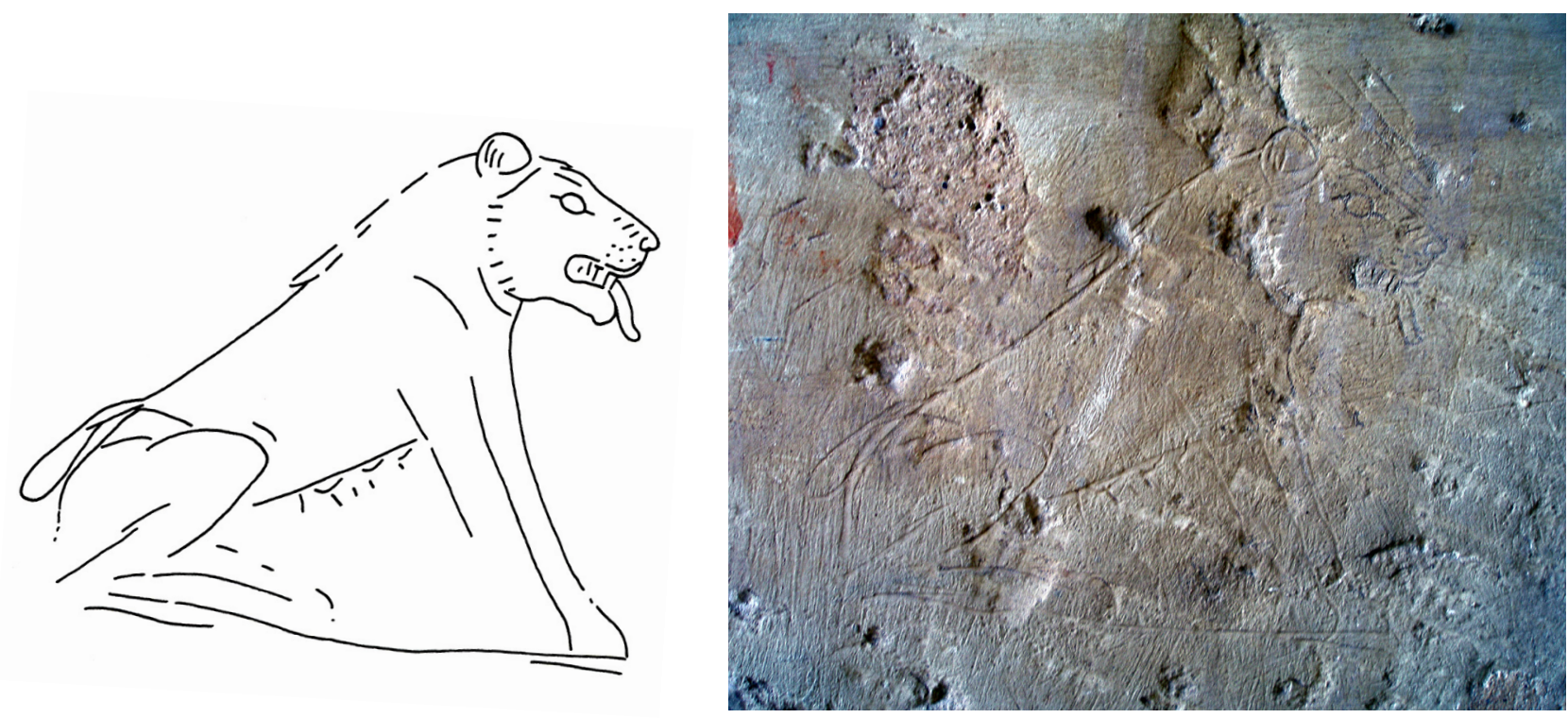

Fig. 17: Graffito of a lioness in the tomb of Maya and Meryt. The skilful execution of the drawing suggests that it was the work of a professional draughtsman. Dimensions: 12 × $14.4 \mathrm{~cm}$. From Martin, Tomb of Maya and Meryt, I, 2012, pl. 62.38. Image courtesy of the Egypt Exploration Society/Rijksmuseum van Oudheden, Leiden. Photograph by Nico Staring. 
still make it a dangerous, apotropaic intercessory in the afterlife. ${ }^{76}$ It is also possible that graffiti of baboons were linked with rebirth and regeneration as a result of the baboon's sexual activity. ${ }^{77}$

Graffiti of lions (Figs. 16-Fig. 17) ${ }^{78}$ can possibly also be interpreted as symbols associated with protection, death, and rebirth. ${ }^{79}$
The lion's extraordinary strength, ferocity, and courage in combat rendered it a suitable protector and guardian against evil forces. This symbolism is evident on amulets, royal thrones, and various types of ritual furniture, such as funerary couches and embalming tables (Fig. 18).

The lion was also portrayed on feeding cups for in-

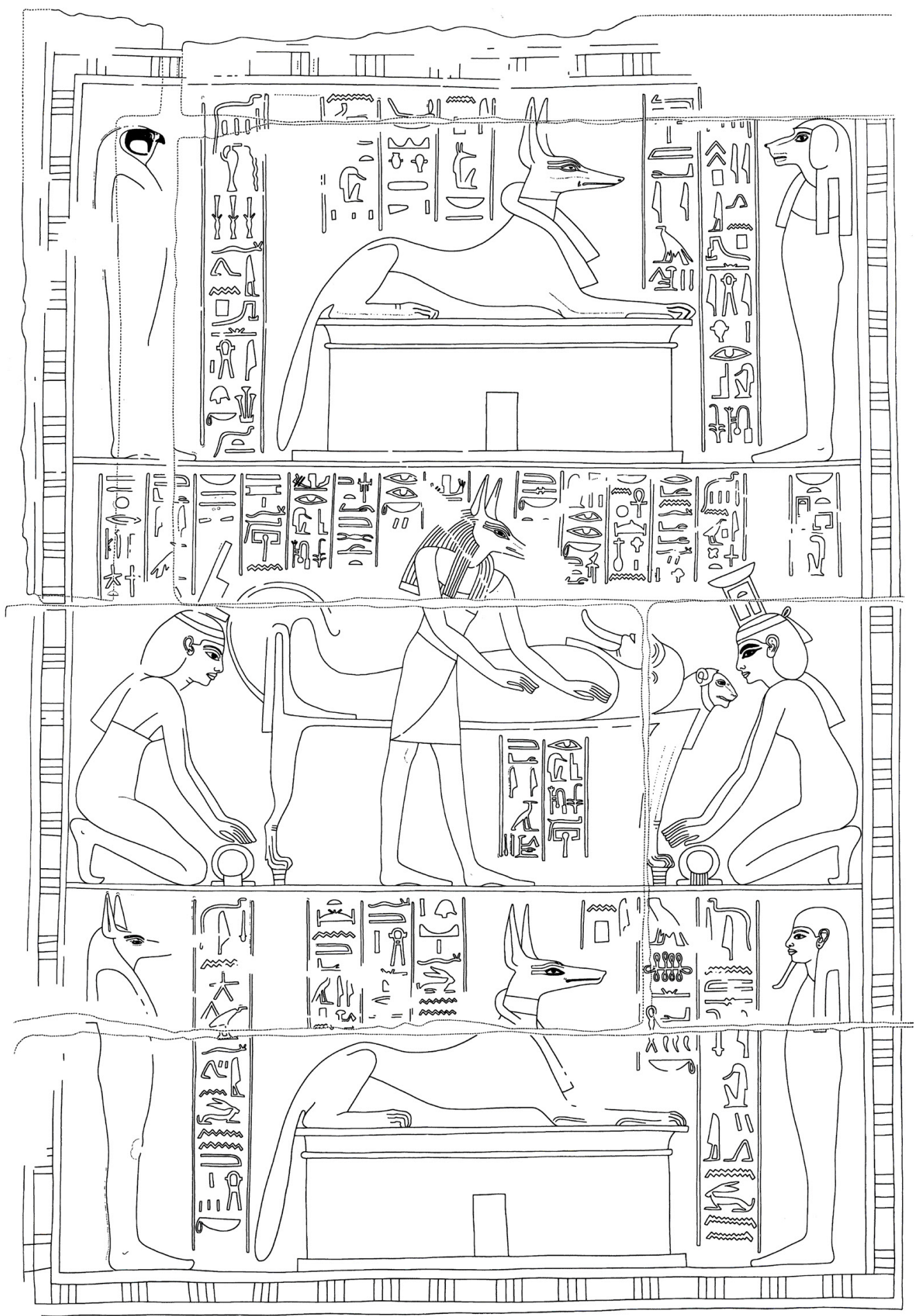

Fig. 18: Relief showing the vignette of Book of the Dead spell 151, depicting the vigil for Osiris during the embalming process. The mummy of Maya lies on a funerary couch decorated with lion heads. Note also the two recumbent jackals on shrines. The text accompanying the bottom jackal unambiguously states its apotropaic function: "Anubis, who is on his hill, who protects the burial (or 'sarcophagus') of this Maya". From Martin, Tomb of Maya and Meryt, I, 2012, pl. 44; translation of text: Id. p. 44. Image courtesy of the Egypt Exploration Society/Rijksmuseum van Oudheden, Leiden. 


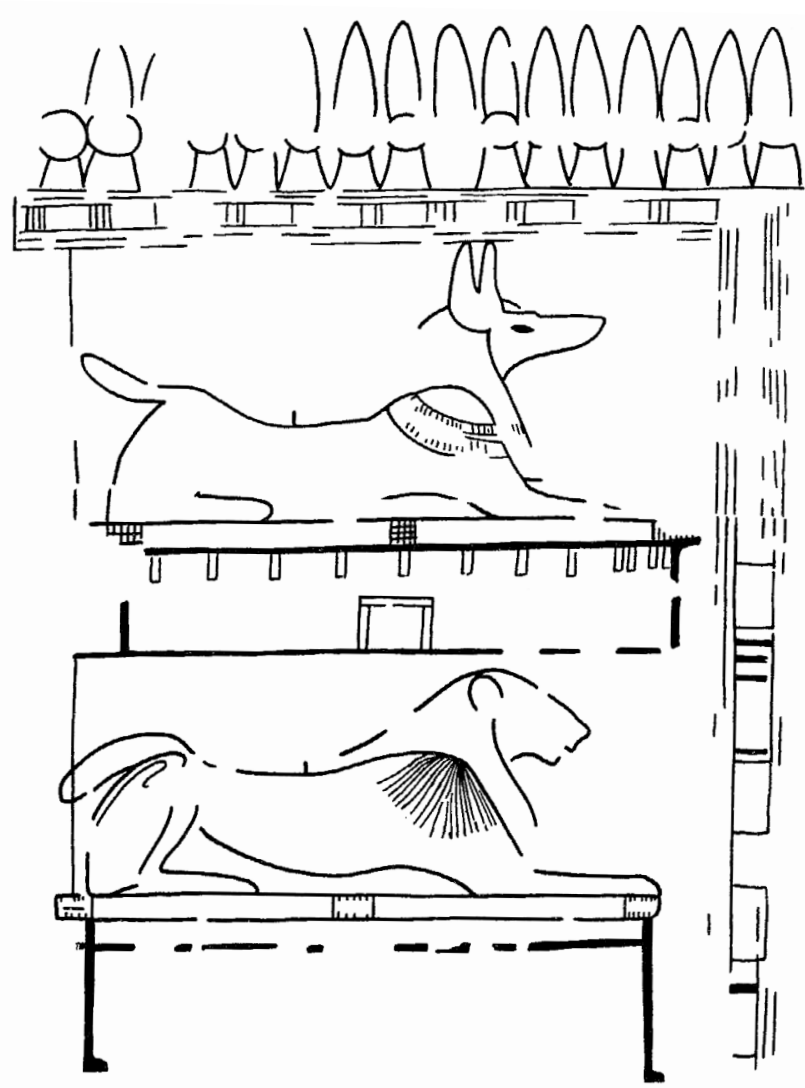

Fig. 19: Depiction of two shrines with a recumbent jackal and lion in the early Nineteenth Dynasty tomb of Amenemope (TT41) in Thebes. Both animals can be interpreted as protectors and guardians of gateways in the Underworld. Image adapted from Assmann, Das Grab des Amenemope, 1991, pl. 66.

fants, magic wands, and rods. On the basis of the occasional inscriptions that accompany these representations, it is clear that they provided protection for pregnant women and infants, whom the Egyptians considered especially vulnerable to evil forces. ${ }^{80}$ From an early age, sculptures of lions were also occasionally set up flanking the entranceways to shrines and temples. Lions depicted in shrines also occur in tombs in the Valley of the Queens and private tombs at Thebes, where they are part of a series of apotropaic deities protecting gateways (Fig. 19). ${ }^{81}$ Leonine imagery furthermore abounds in ancient Egyptian religious iconography and is associated with various deities in the Pharaonic pantheon, including lioness goddesses such as Tefnut, Pakhet, Bastet, and Mut. Most notably, there was Sekhmet, the consort of Ptah at Memphis, who was represented as a woman with the head of a lioness. The name of the goddess, "The Powerful One", refers to her wild and potentially dangerous character, which was a common feature of leonine goddesses. ${ }^{82}$ Sekhmet was considered the protector of the Pharaoh and the gods, and beginning in the Eighteenth Dynasty (as early as the reign of Thutmosis III), she had a special place of reverence in the southern part of the pyramid temple of Sahure at Abusir as "Sakhmet of Sahure". 83 Graffiti, stelae, and private votive statuettes found at the site provide evidence for the existence of a cult. It may be this goddess who is represented in a lioness graffito in the tomb of Maya and Meryt (Fig. 17). Lions also had strong solar associations. Most notably, the lion-god Aker guarded the gateway to the Netherworld through which the sun-god passed each day, allowing him to be born each morning and die each evening. In sum, lion graffiti in tombs may be interpreted as potent symbols of protection and/ or rebirth, ensuring that the deceased would be protected and reborn in the afterlife.

Graffiti of geese (Fig. 20) may likewise be associated with the regenerative associations of the animal. ${ }^{84}$ According to Coffin Texts spell 223, the world hatched out of an egg laid by the "Great Cackler" or "Great Honker", and the deceased is himself presented as another egg inside that Great Cackler waiting to hatch in the same way. In Pyramid Texts spells $336 \mathrm{a} / \mathrm{b}$ and $1122 \mathrm{a} / \mathrm{b}$ the deceased king hopes to ascend to the sky in the form of a goose. Funerary statuettes of geese discovered in the royal tombs in the Valley of the Kings are presumably a later expression of these regenerative ideas. ${ }^{85}$

A graffito of a goose on the roof of the Khonsu temple at Karnak (Fig. 21) can potentially be interpreted

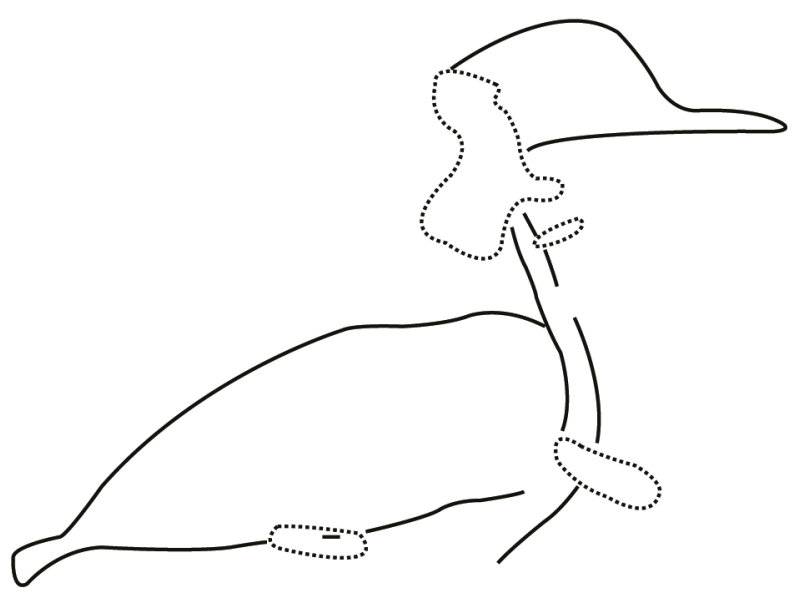

Fig. 20: Graffito of a goose in the tomb of Horemheb. Dimensions: $7.8 \times 11 \mathrm{~cm}$. From Martin, Memphite Tomb of Horemheb, I, 1989, pl. 147.16. Image courtesy of the Egypt Exploration Society/Rijksmuseum van Oudheden, Leiden. 


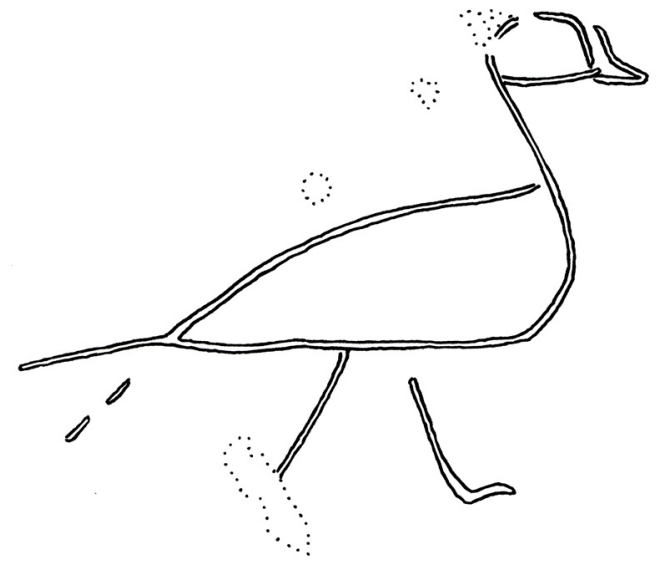

Fig. 21: Graffito of a goose on the roof of the temple of Khonsu at Karnak. Dimensions: $24 \times 30 \mathrm{~cm}$. From JacquetGordon, Graffiti on the Temple Roof, 2003, pl. 53.140. Image courtesy of the Oriental Institute of the University of Chicago.

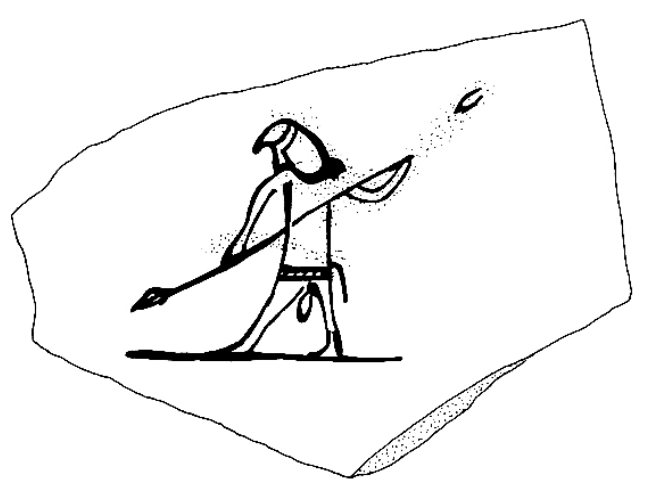

Fig. 23: Late Period pottery ostracon with a depiction of a hieracocephalous deity holding a spear, painted in black pigment. Dimensions: $13.5 \times 15.9 \times 1.8 \mathrm{~cm}$. From Martin, Three Memphite Officials, 2001, pl. 33.63. Image courtesy of the Egypt Exploration Society/Rijksmuseum van Oudheden, Leiden.

as a symbol of Amun. The Nile goose was associated with this god because of its association with the creation of the primeval world. ${ }^{86}$

Another graffiti-motif with a probable apotropaic function is that of the warrior with shield and spear (Fig. 22).

This motif is reminiscent of depictions of hieracocephalous deities found on Late Period ostraca in the Saqqara area (Fig. 23). These have been interpreted as depicting Horus combating Apophis, as represented, for example, on contemporary hypocephali. ${ }^{87}$ It is possible that these ostraca, like certain types of graffiti, should be interpreted as products of meaningful ritual acts rather than mere trial pieces or idle sketches. ${ }^{88}$ This hypothesis is not unattractive as the imagery of other ritual graffiti, such as lions, ${ }^{89}$ wedjat eyes, ${ }^{90}$ lotus flowers, ${ }^{91}$ and gods, ${ }^{92}$ commonly appears on os-

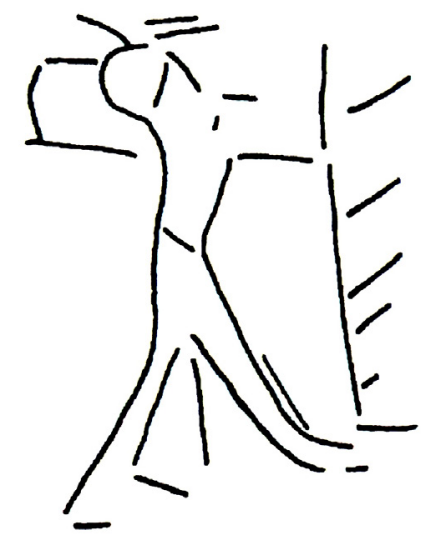

Fig. 22: Graffito of a warrior with a shield and spear in the tomb of Maya and Meryt. Dimensions: $6.4 \times 4.6 \mathrm{~cm}$. From Martin, Tomb of Maya and Meryt, I, 2012, pl. 61.27. Image courtesy of the Egypt Exploration Society/Rijksmuseum van Oudheden, Leiden.

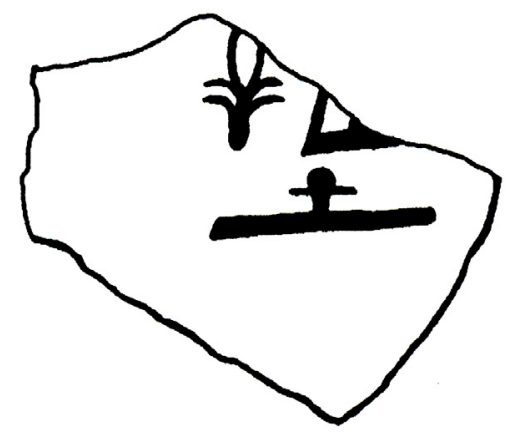

Fig. 24: Pottery ostracon from the tomb of Tia and Tia showing part of the $h t p-d i-n s w$ formula. Dimensions: $5.2 \times 6 \times 0.8 \mathrm{~cm}$. From Martin, Tomb of Tia and Tia, 1997, pl. 104.74. Image courtesy of the Egypt Exploration Society/ Rijksmuseum van Oudheden, Leiden.

traca found in the New Kingdom tombs at Saqqara. ${ }^{93}$ Particularly suggestive of a ritual function are two ostraca from the tomb of Tia and Tia, which contain a part of the htp-di-nsw formula (Fig. 24), and a depiction of a smoking, arm-shaped censer with the name of Amun in hieroglyphs below (Fig. 25). ${ }^{94}$ The $h t p-d i-n s w$ formula is a well-known offering connected with the provision of the deceased that is understood as part of a ritual, ${ }^{95}$ while censing rites were endowed with magic and associated with themes of rejuvenation and deification. ${ }^{96}$

In some cases the ritual interpretation of ostraca gains additional support from the character of their decoration. While certain examples contain depictions of great artistic merit (Fig. 26), others bear only crudely executed representations that can hardly be considered trial pieces or sketches for wall reliefs 

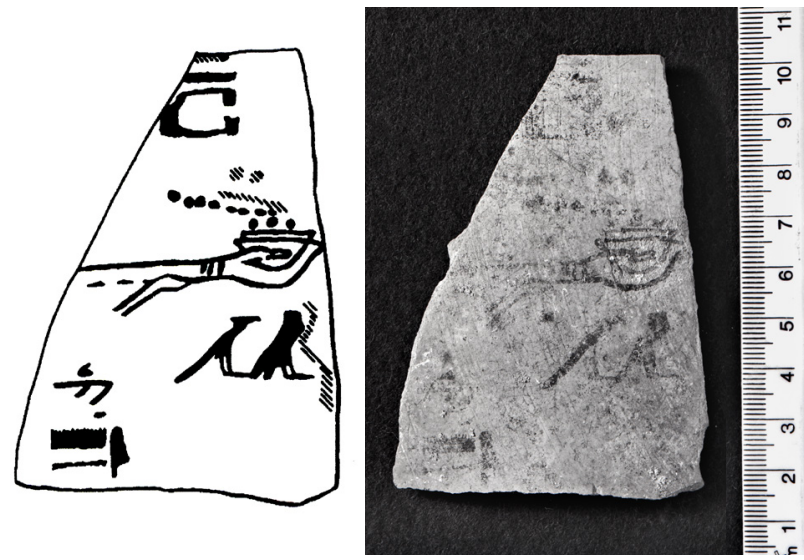

Fig. 25: Pottery ostracon from the tomb of Tia and Tia showing a censer and the name of Amun written in hieroglyphs below. Dimensions: $8.8 \times 6.2 \times 0.85 \mathrm{~cm}$. Drawing from Martin, Tomb of Tia and Tia, 1997, pl. 104.75. Image courtesy of the Egypt Exploration Society/Rijksmuseum van Oudheden, Leiden. Photograph courtesy of the Rijksmuseum van Oudheden, Leiden. from the hand of an accomplished draughtsman (Fig. 27). Like graffiti, ostraca could be created by individuals at little to no financial cost to themselves. In addition, ostraca were highly portable, meaning that they could have been prepared at a time and place convenient to the donor, for example within the home, in anticipation of a visit to the necropolis. Further possible ritual graffiti include a graffito on an unfinished stela from the tomb of Mery-Neith. ${ }^{97}$ This graffito depicts a standing mummy that is being held by a kneeling widow (Figs. 29).

The scene is very similar to offering scenes attested elsewhere in the Leiden-Turin concession area. ${ }^{98}$ For example, a scene in the tomb of Khay shows Khay's mummy standing in front of his tomb-chapel with his widow kneeling at his feet and his son burning
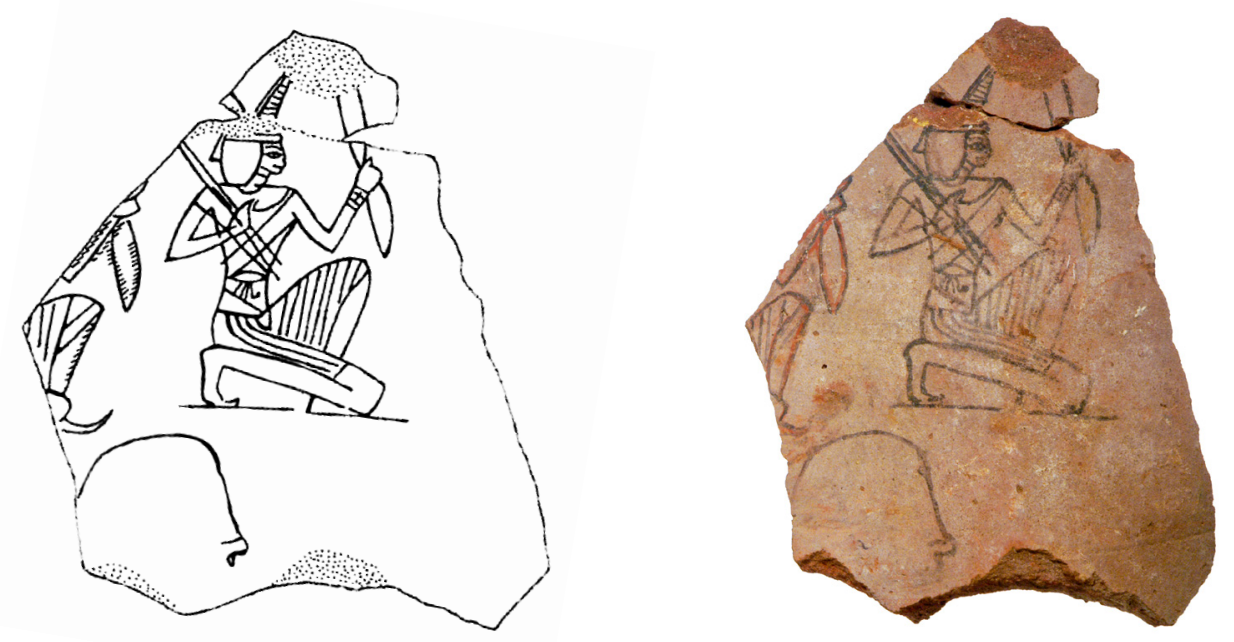

Fig. 26: Pottery ostracon depicting two nearly identical kneeling bowmen. The figure on the right is painted in black only. The figure on the left, on the other hand, is executed in red and corrected in black, which may indicate that this was a pupil's copy. Dimensions: $11.8 \times 9.9 \times 0.65$ cm. Drawing from Raven et al., Memphite Tomb of Horemheb, V, 2011, p. 105, Cat. 107. Image and photograph courtesy of the Rijksmuseum van Oudheden, Leiden.
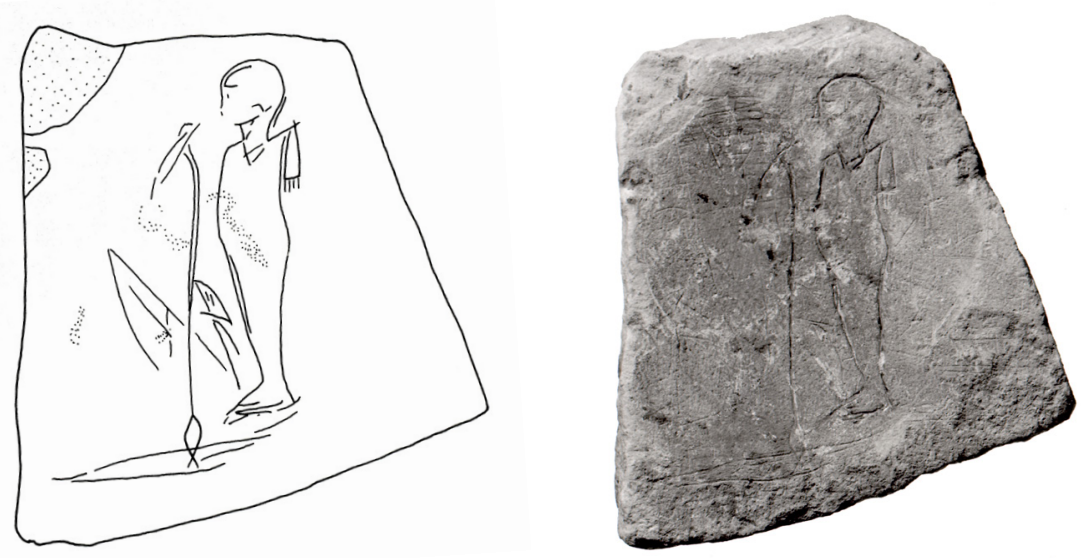

Fig. 27: Limestone ostracon with a painted representation of Ptah with w3s sceptre and $m$ ' $n h t$ tassel. The outlines of the figure are roughly incised. Dimensions: $12.5 \times 11.5 \times 2.5 \mathrm{~cm}$. Drawing from Raven, Tomb of Maya and Meryt, II, 2001, pl. 31.34. Image courtesy of the Egypt Exploration Society/Rijksmuseum van Oudheden, Leiden. Photograph courtesy of the Rijksmuseum van Oudheden, Leiden. 


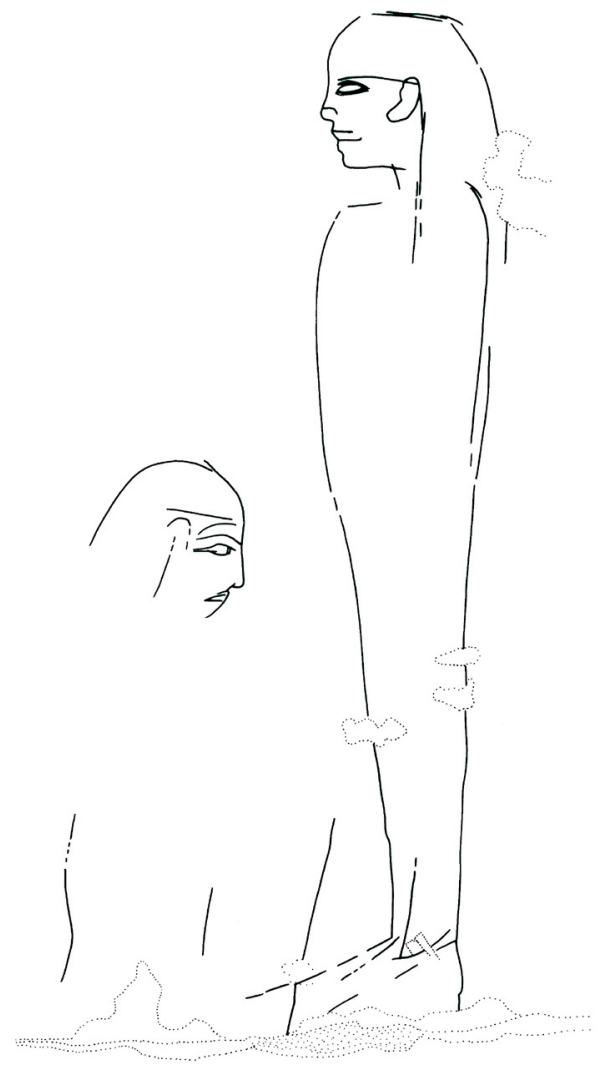

Fig. 28: Graffito of a standing mummy embraced by a kneeling widow incised on the lower slab of a stela that was probably never carved. The slab was found in the tomb of Mery-Neith. Dimensions: 44 x $18 \mathrm{~cm}$. From Raven et al., Tomb of Meryneith at Saqqara, 2014, p. 81 [4]. Image courtesy of the Rijksmuseum van Oudheden, Leiden.
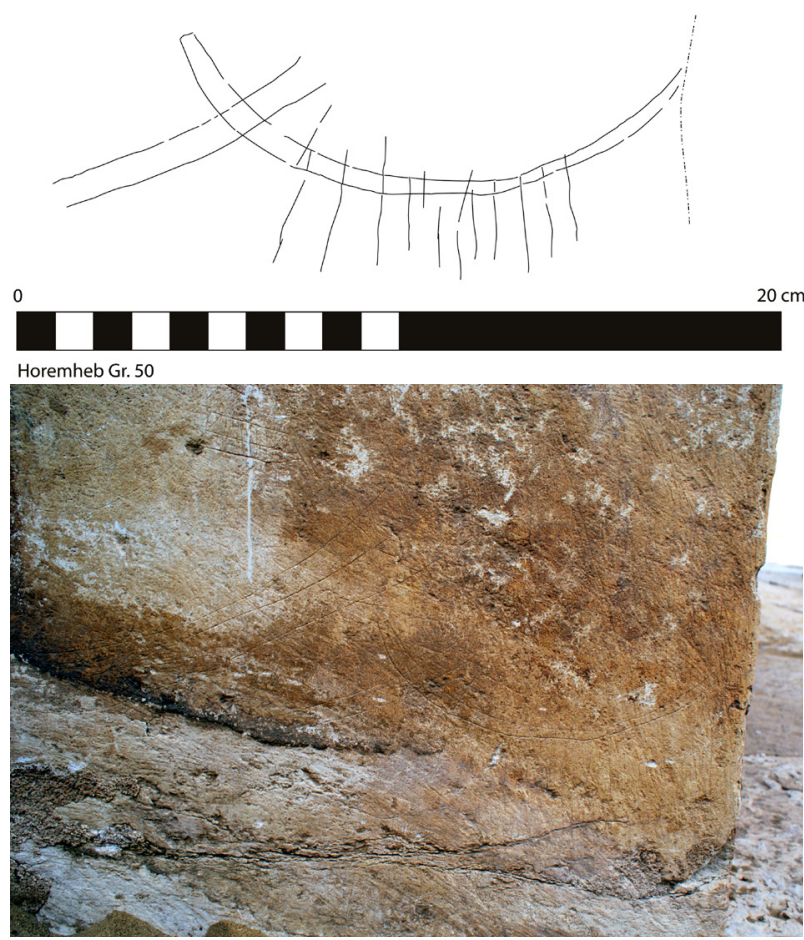

Fig. 30: A crudely-drawn ship with oars in the tomb of Horemheb. Drawing and photograph by Nico Staring.

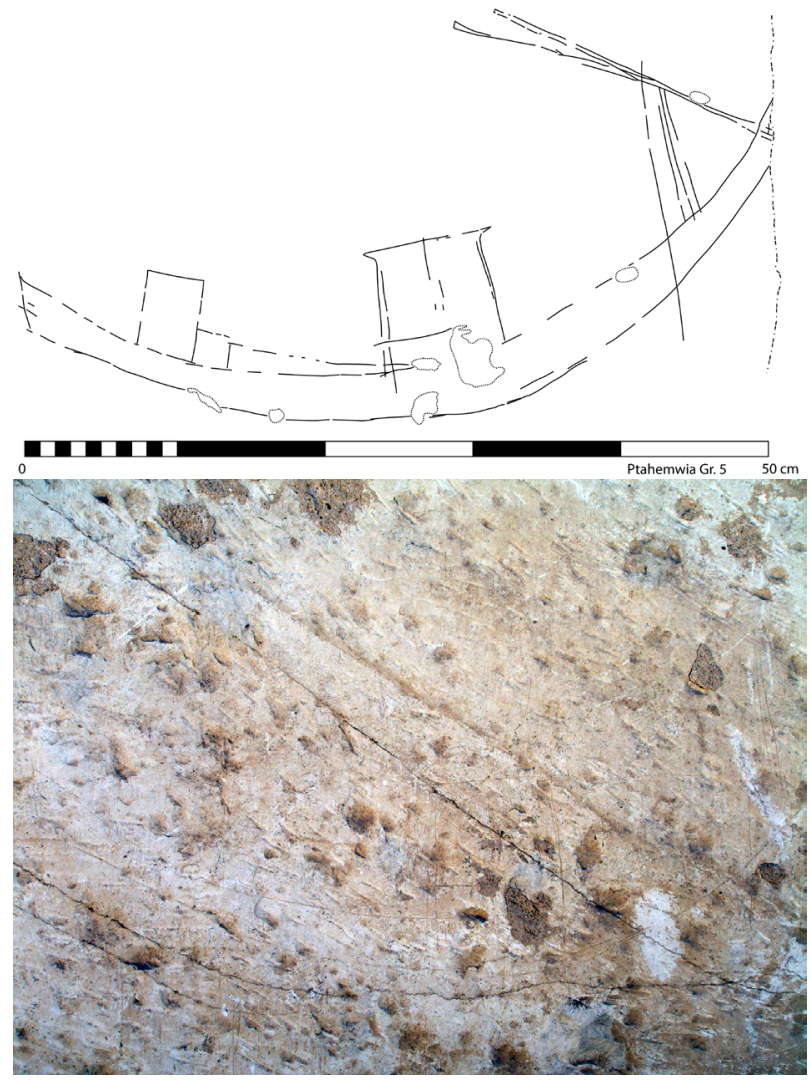

Fig. 29: Graffito of a ship with a slightly curved body in the tomb of Ptahemwia. Drawing and photograph by the authors.

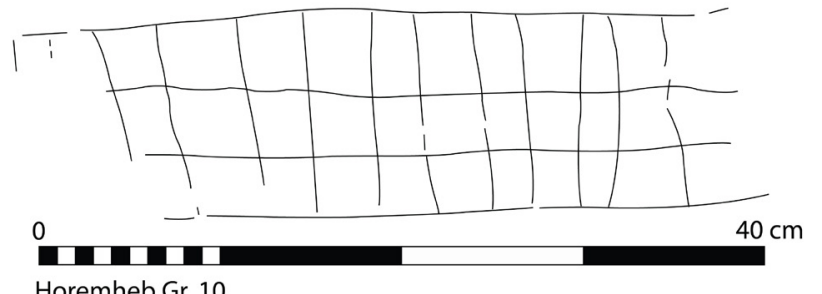

Horemheb Gr. 10

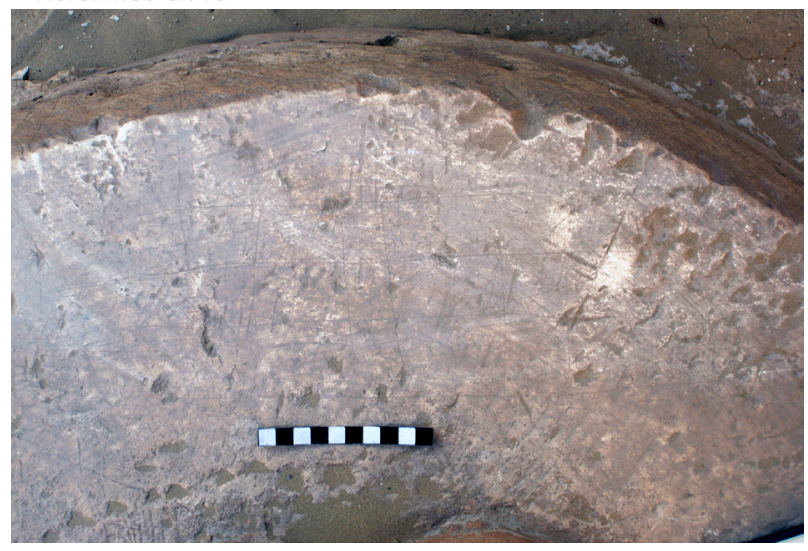

Fig. 31: Graffito of a gaming board scratched on a column bases in the tomb of Horemheb. From Martin, Memphite Tomb of Horemheb, I, 1989, pl. 46.10. Image courtesy of the Rijksmuseum van Oudheden, Leiden. Photograph by Nico Staring. 
incense. ${ }^{99}$ Above, 12 columns of text illustrate the depicted activity, reading:

Burning incense for Osiris, foremost of the West, Wenennefer, lord of the [Sacred Land?], that he may give offerings which come forth (upon his altar) to the Osiris, the overseer of traders Khay, [justified].

Potentially, the graffito in the tomb of Mery-Neith acts as a synecdoche for such an offering scene, in which case its ritual connection to the maintenance of the dead would be clear. ${ }^{100}$

The large numbers of ship graffiti in the Saqqara necropolis are more ambiguous in nature. ${ }^{101}$ The ships in the necropolis represent modest river boats rather than sacred barques, and as such their creation may be rooted as much in mirth as in piety. Twentieth-century ship-graffiti from Newfoundland, Canada, suggest that of key significance may be their potential to convey the relative importance of ships and shipping within the society of the graffitists. ${ }^{102}$ The Nile was a vital waterway for the transportation of people and goods from the earliest times of Egyptian history. It would not be a matter of surprise, therefore, if similar ideas prompted the production of a number of Egyptian ship graffiti (Figs. 29, 30). Another possibility is that certain ship graffiti simply represent idle sketches. Ships form a common element of the tomb iconography of all periods and could have inspired graffitists to create similar images. On the other hand, the funerary context of the graffiti may also suggest that they had a deeper meaning. Perhaps ship graffiti in tombs were intended to provide symbolic transportation for the deceased to help them undertake journeys in the hereafter, such as the pilgrimage to Abydos. ${ }^{103}$ It is also possible that ship graffiti were left as a thanksgiving for a safe passage to the tomb ${ }^{104}$ or commemorated the presence of the graffitist in a manner comparable to the plantae pedis. ${ }^{105}$ It may be significant in this respect that nearly all of the ship graffiti in the New Kingdom necropolis were left at tomb entrances.

The meaning of gaming board graffiti is also open to various interpretations (Fig. 31). These graffiti may simply have provided a physical surface for mundane amusement, but they also could have carried ritual connotations. The introduction to Chapter 17 of the Book of the Dead describes the deceased playing the game of senet. The accompanying vignette shows the deceased seated at a checkerboard playing against an invisible opponent. The lack of an opponent suggests that, at least during the New Kingdom, senet became a metaphor for the deceased's journey into the afterlife in which winning the game was equated with a safe arrival and acceptance in the underworld. ${ }^{106}$ Perhaps graffiti of gaming boards were made with this idea in mind and were intended to be used by the deceased to ensure his or her rebirth. It is also possible that such boards were used by the living to ritually ensure the well-being of their deceased relatives.

As suggested by an inscription from the Saite tomb of Ibi, copying parts of the tomb decoration may sometimes also have been encouraged by the deceased. ${ }^{107}$
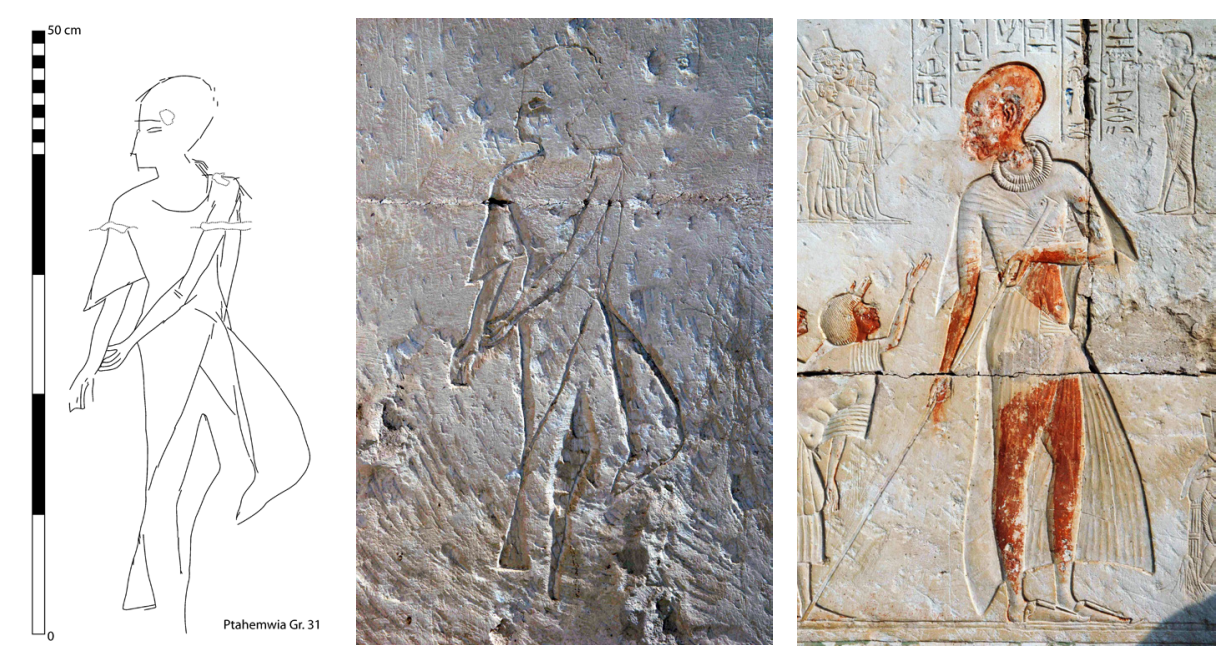

Fig. 32: Graffito copying a depiction of Ptahemwia on the north wall of the tomb. The graffito was carved on the east wall of the tomb in viewing distance of the original (photo on the right-hand side). Drawing by the authors. Photographs courtesy of the Rijksmuseum van Oudheden, Leiden. 
Most remarkable in this context is the attempt by a graffitist to copy a depiction of Ptahemwia on the north wall of his tomb (Fig. 32). Because all images of the deceased, in relief or painted depictions or even in spellings of their name, could function as a secondary repository for the spirit, leaving such images may have been considered a benevolent act.

A special group of graffiti that has so far remained unmentioned is that of depictions of royalty. The marked stress on such graffiti in the Leiden-Turin concession area has been connected with the later cult of Horemheb and his queen, Mutnodjmet, who was buried here, when this king's private tomb was nominally transformed into a royal memorial temple. ${ }^{108}$ The limestone elements of the entrance gateway to the tomb display a marked patina and numerous shallow scratches, as if they were exposed to the elements and suffered from the passage of numerous visitors. It does not seem unreasonable to postulate that some participants of the cult left graffiti of royalty, most notably royal heads, as part of ritualistic acts. Perhaps these graffiti served as votive offerings seeking grace or giving thanks to the King. Several graffitists may have subsequently deviated from their course and left graffiti of royalty in the surrounding tombs as well (Fig. 33). ${ }^{109}$ While this association between the cult of Horemheb and the graffiti of royalty is plausible, it is important to note that royal head graffiti are not restricted to the Saqqara area alone. Similar representations can be observed in Abydos, ${ }^{110}$ Asyut, ${ }^{111}$ and Karnak, ${ }^{112}$ albeit much less frequent in number. However, at places like Abydos and Karnak there would have been numerous royal figures in the existing temple decoration that could have inspired graffitists to create similar depictions. In private tombs the situation was very different - especially at Saqqara where, compared to Thebes, only a limited number of tombs contained official depictions of the King. When drawing these seemingly disparate motifs together, it becomes clear that many figural graffiti represent symbols that focus on themes of rebirth, regeneration, and the protection of the deceased. This choice of subject matter, combined with the funerary context of the graffiti, suggests that such symbols were left as part of a conscious effort by the living to influence the fortunes of the deceased. ${ }^{113} \mathrm{At}$
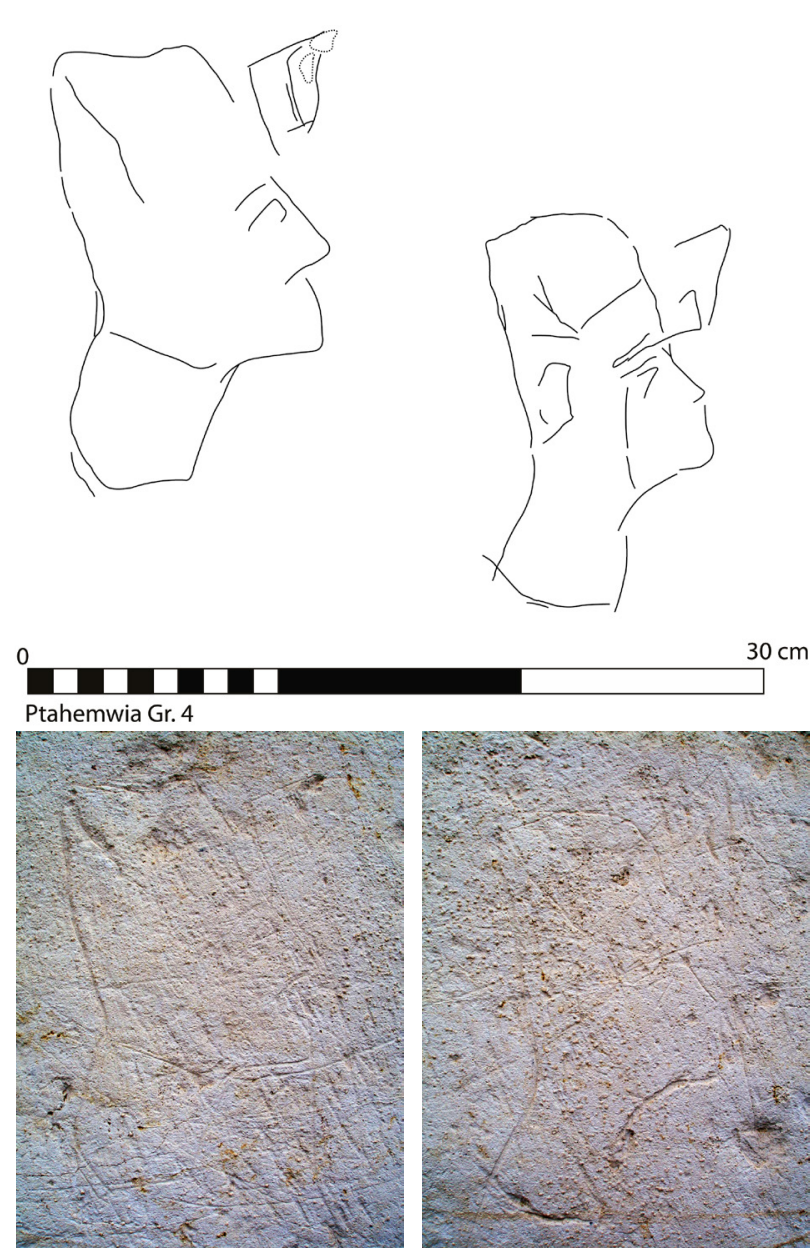

Fig. 33: Graffiti of two royal heads with blue crown adorned with a uraeus in the tomb of Ptahemwia. Drawing and photographs by the authors.

the same time, graffitists may have aimed at receiving benefits and blessings for themselves in return for the services rendered. The Addresses to the Living suggest, at least, that the deceased were willing to reciprocate appropriate and intended behaviour by the living:

\footnotetext{
"It is one whom the king loves, it is one whom Anubis loves, he who will..., I will be [their backer] in that noble [council], (for) everything effective and special that has been done for (me)".114
}

If the purpose of the accessible spaces of a tomb was to provide a space to commemorate and perform rituals for the deceased, ${ }^{115}$ then leaving protective symbols in the form of figural graffiti can be understood as meeting such expectations. They can be seen as part of the Besucherkult, answering to the implicit and, in case an Address to the Living was present, explicit wishes of the tomb-owner for 
maintenance and protection. ${ }^{116}$ Navrátilová ${ }^{117}$ and Ragazzoli ${ }^{118}$ already made a similar argument with regard to visitor inscriptions (Besucherinschriften). However, figural graffiti, too, can be seen as part of the magical mechanics that the living employed to interact with the deceased and the funerary gods after burial.

Importantly, Navrátilová and Ragazzoli both embed the phenomenon of graffiti making within a broader framework of commemoration and representation that was practised by the literate elite. Yet, the strong emphasis on written graffiti necessarily restricts the range of practitioners to this group. If, on other hand, the idea is accepted that literacy was not a requirement for the production of figural graffiti in tombs, ${ }^{119}$ then it is possible to suggest that graffiti making may also represent aspects of popular piety at its most fundamental level, namely the informal, directly personal dialogue between an individual, the deceased, and the gods of the necropolis. Educated scribes and priests were in many ways essential to the performative magic of the tomb and the circulation of offerings, but it must be acknowledged that a large number of illiterate and less-literate individuals would also have been able to interpret and react meaningfully to information presented in tombs in the form of an image. ${ }^{120}$ The use of items such as amulets cut across boundaries of wealth and class. ${ }^{121}$ It seems reasonable to assume, therefore, that many ancient Egyptians would have been familiar with the significance and basic meaning of common religious symbols such as the wedjat and could have drawn from this knowledge to encode and decode messages and desires through figural graffiti. ${ }^{122}$ The contents of humble graves throughout Egypt furthermore suggest that the same basic necessities for maintenance and protection in the afterlife applied whatever the economic level of the deceased. ${ }^{123}$ As a corollary, it is highly likely that many Egyptians would have understood the function of a tomb or a grave as a place of commemoration and cult and had some understanding of what kind of behaviours and practices were appropriate and desired in a funerary landscape. ${ }^{124}$ It should be stressed that cues for expected modes of conduct were also encoded in the built environment itself, in the architecture, decoration, and furnishings of the tomb, which would have helped to make behaviour more constant and reduced the problem of totally idiosyncratic interpretation of the tomb space. ${ }^{125}$ Such non-verbal prompts would have been much more "readable" and easier to decode when the tombs were still in use, and ritual actors, their dress, behaviour, interaction, language (e.g. incantations), sounds, and smells could still be directly observed by visitors to the necropolis.

Whereas the traditional trappings of self-presentation and religious expression in elite burials, such as stelae and statues, were expensive and exclusionary, graffiti could be created by individuals at no financial cost to themselves. They can perhaps be interpreted as low-cost forms of representation and commemoration that met the affordances and restrictions of the poorer and illiterate echelons of Egyptian society. ${ }^{126}$ Just because graffiti would have been free or inexpensive to make is no reason to suppose that they would have been considered of lesser value than more formalised modes of ritual expression. The existence of invocation offerings, which caused no financial hardship for the speaker but nevertheless benefitted the deceased, clearly indicates that the value of ritual action was judged in more ways than simply financial. In fact, graffiti may have been considered a particularly-valued component of the cultic "tool-kit" because they produced an enduring effect by being incised into the very fabric of the tomb itself. This means that graffiti, unlike statuettes, stelae, and ostraca, could not be easily removed from the tomb or de-contextualised.

\subsection{Graffiti as secular expressions}

While many textual and figural graffiti can be interpreted as resulting from ritualised or devotional acts, this by no means holds true for all ancient graffiti. The reason for choosing more secular motifs, such as certain geometric patterns, may rather have been driven by a jeux d'esprit or boredom. Although geometric shapes may have been used as identity markers in a pseudo-script, ${ }^{127}$ this is often difficult to prove beyond reasonable doubt, at least in the context of the Saqqara necropolis. Geometric shapes also do not appear to have had any intrinsic or apparent ritualistic properties. ${ }^{128}$ Examples of jeux d'esprit in the tomb of Ptahemwia may include a hieratic graffito, including part of the scribal text 

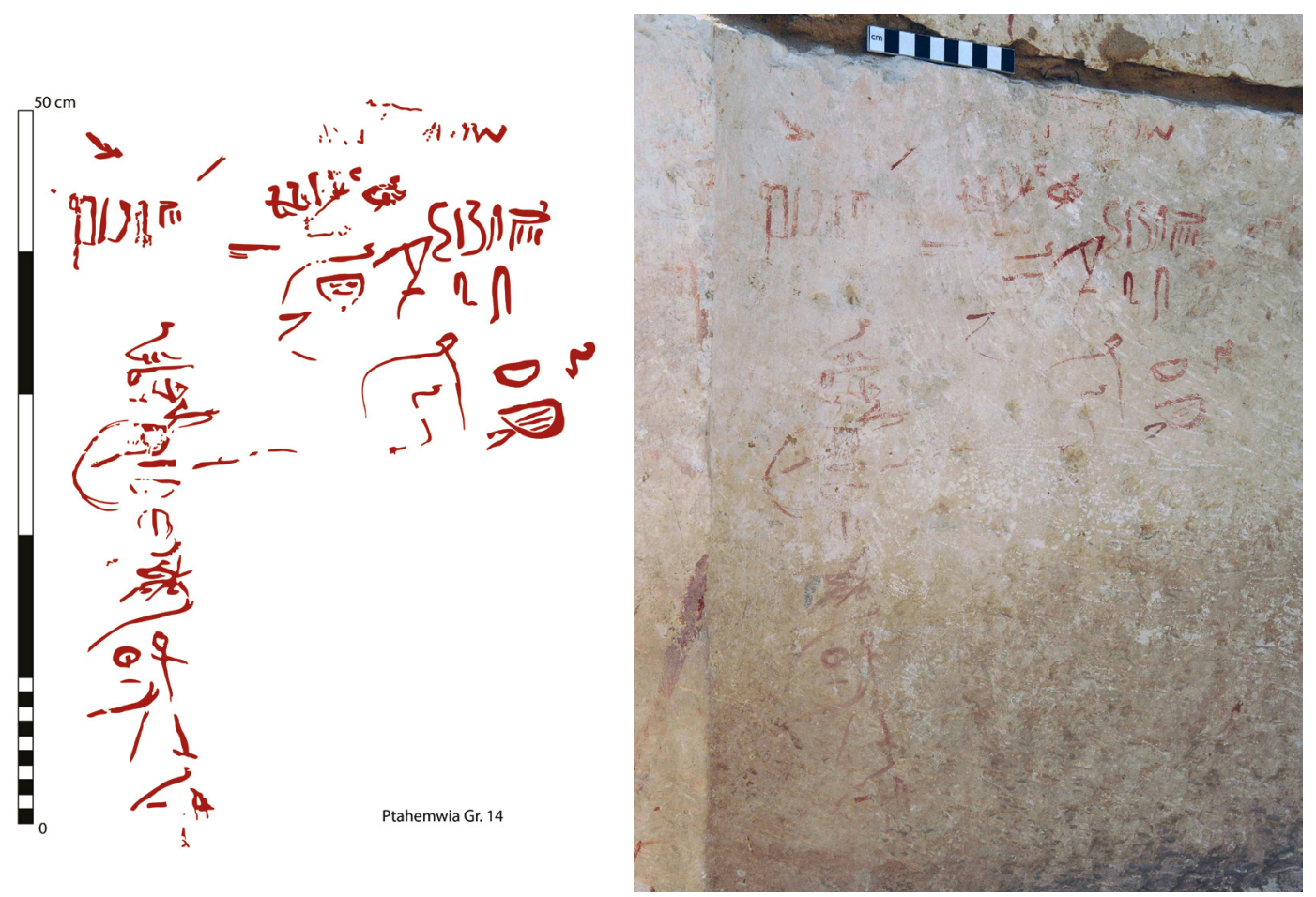

Fig. 34: Hieratic inscription in red ochre, consisting of one unframed column of hieratic and two horizontal lines with several loose signs without coherent meaning. The unframed column contains the first sentence of a well-known scribal exercise, the so-called Kemyt: "It is a servant who addresses his lord, whom he wished to live, be prosperous and healthy." Possibly the two separate groups to the left and right can be translates as " $A u^{\prime}$ ", who is the chief protagonist of the narrative section of the Kemyt. Demarée, Saqqara Newsletter 7 (2009), pp. 11-12. Drawing by the authors. Photograph courtesy of the Rijksmuseum van Oudheden, Leiden.

Kemyt, made by an apprentice scribe practising his art (Fig. 34).

Making graffiti as part of an informal, pleasurable activity is also mentioned in textual graffiti commemorating a "stroll" in which the graffitist explicitly states that he came to visit the necropolis simply to "amuse" or "invigorate" himself. ${ }^{129}$ While such mundane scribbles may approximate modern connotations of the term graffiti as mindless defacements, one should here too remain cautious not to make too apodictic statements. Most remarkable, especially given their significant quantity, is how unobtrusive the graffiti in the Leiden-Turin concession area are. Most graffiti are careful to respect the existing tomb decoration, the majority being located on the dado of the limestone casing and on undecorated wall surfaces in the courtyard. While this may be hardly surprising from a practical point of view - graffiti are better visible when not interfering with existing decoration and their size and number is also dependant on the amount of relatively flat space available - this observation does suggests that defacement of the monuments was not the intention of those who left graffiti in the tombs of the Leiden-Turin concession area. ${ }^{130}$ There is no erasing of elements or attempting to "appropriate" the tombs; indeed, many of the graffiti hardly aimed at attracting an observer's attention. Many examples are only shallowly incised below eye level and are quite difficult to discern even at close inspection, especially in direct sunlight. This suggests that the physical presence of the graffiti within the sacred space of the tomb was more important than their visibility.

\section{Spatial distribution and relative im- portance of figural and textual graffiti}

The following section considers the distribution and relative importance of textual and figural graffiti in the Saqqara New Kingdom necropolis as a whole, as this may provide insights into how space was used, where graffiti have a tendency to appear, and in what way(s) graffiti were conditioned by the space in which they were executed. A corpus of 243 graffiti was compiled from nine New Kingdom tombs (224 graffiti) and stone elements from the Saqqara New Kingdom necropolis presently in public or private 


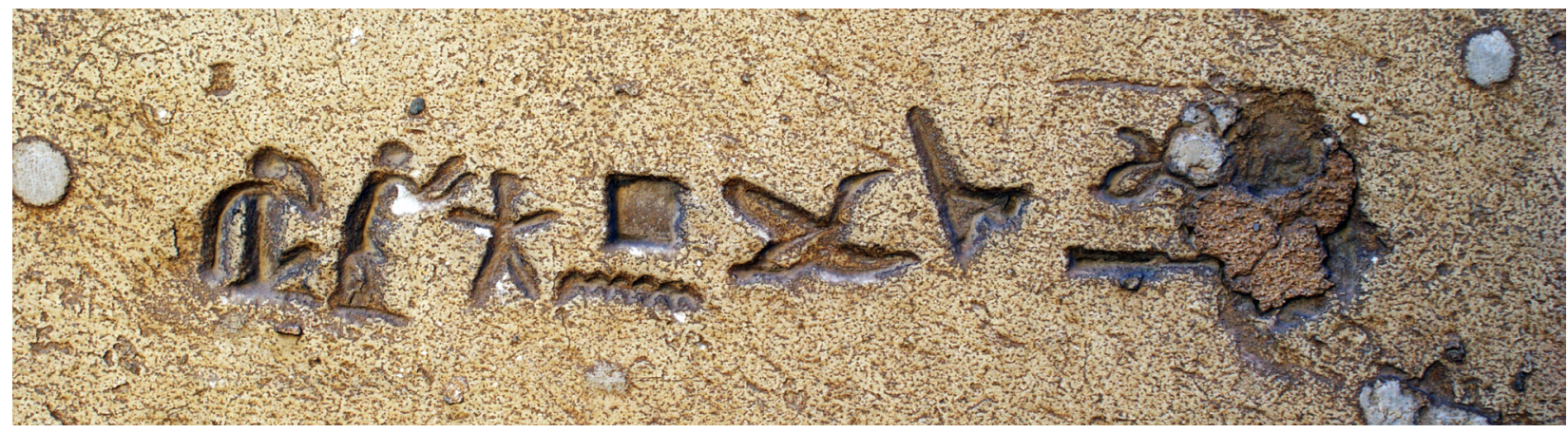

Fig. 35: Hieroglyphic graffito in proper sunk relief in the tomb of Horemheb (second pylon, doorway), mentioning the sculptor Pendua. Dimensions: 4.6 x $18.6 \mathrm{~cm}$. Photograph by Nico Staring.

collections (19 graffiti). ${ }^{131}$

Out of the 243 graffiti identified, 202 are figural (83.1\%) and $41(16.8 \%)$ textual. This shows that in the Saqqara New Kingdom necropolis it was far more common to leave figural graffiti than to leave texts. ${ }^{132}$ The textual graffiti can be subdivided according to script: hieroglyphic $(\mathrm{n}=19)$ and hieratic $(n=22)$. The almost even distribution of hieroglyphs and hieratic is noteworthy. ${ }^{133}$ Hieroglyphs were normally used only for monumental texts, whereas hieratic was used for quotidian purposes such as writing administrative documents, legal texts, and letters. Although scribes generally would have been more familiar with hieratic, many of the graffitists in the New Kingdom tombs appear to have adapted their script to "fit" the monumental hieroglyphs used in funerary contexts, which were aimed at securing eternity (Fig. 35). ${ }^{134}$ This use of the hiero-

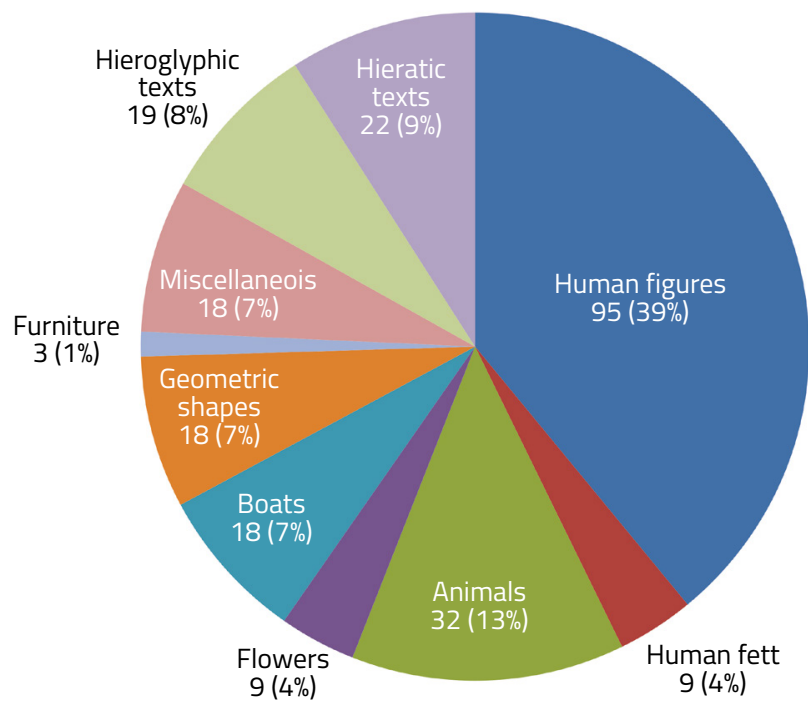

Fig. 36: Graffiti groups recorded in the New Kingdom necropolis at Saqqara. Graph by the authors. glyphic script may reflect an immersion of the graffiti in the "divine" world of the deceased rather than them being embedded in the "profane" world of the living through the use of hieratic.

Following Dijkstra, ${ }^{135}$ the figural graffiti can be divided into eight groups: human figures ( $\mathrm{n}=95)$, human feet $(n=9)$, animals $(n=32)$, flowers $(n=9)$, boats $(n=18)$, geometric shapes $(n=18)$, furniture $(n=3)$, and miscellaneous ( $\mathrm{n}=18$ ) (Fig. 36). ${ }^{136}$ The "human figures" category is the largest, with 95 examples. Of these, 40 depict only heads. "Animals" represent the second largest category. Most species are only attested once (bovid, dog, crocodile, fish) or twice (horse, lion). Only three species occur more often and across several tombs: jackals $(n=11)$, monkeys $(n=7)$, and birds $(\mathrm{n}=5)$.

The spatial distribution of figural graffiti (Fig. 37) shows that there was a clear preference to leave figural graffiti in tomb entrances (40.1\%). The courtyards of the tombs were also a popular space for leaving figural graffiti (32.7\%). Further into the tomb, towards the west, the number of figural graffiti decrease, and only very few figural graffiti are found in the chapels at the rear end of the tomb. ${ }^{137}$ While at first glance it may be somewhat surprising to find so many figural graffiti in the relatively narrow entrances and passageways of tombs, the entrance is a place where a visitor may pause to get his or her bearings upon entering the tomb. Additionally, it may have been a pleasant location to sit in hot weather as there may have been shadow or a cooling draught. People would also have passed through entrances relatively frequently, thereby increasing the potential for inscribing, reading, and responding to existing graffiti. ${ }^{138}$ On a more metaphysical level, the 


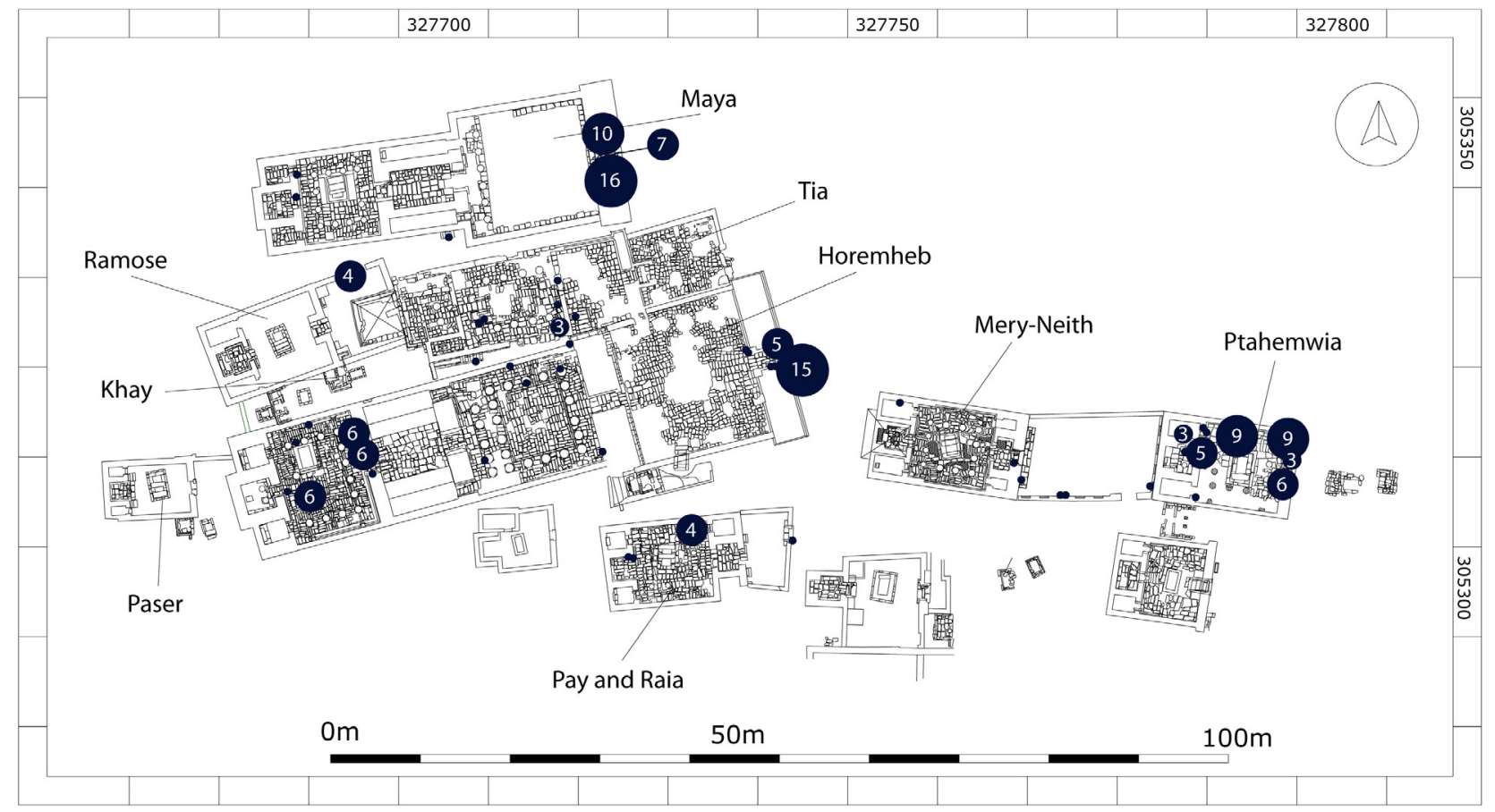

Fig. 37: Distribution of figural graffiti in the Saqqara New Kingdom necropolis, Leiden-Turin concession area (2013). Map by the authors.

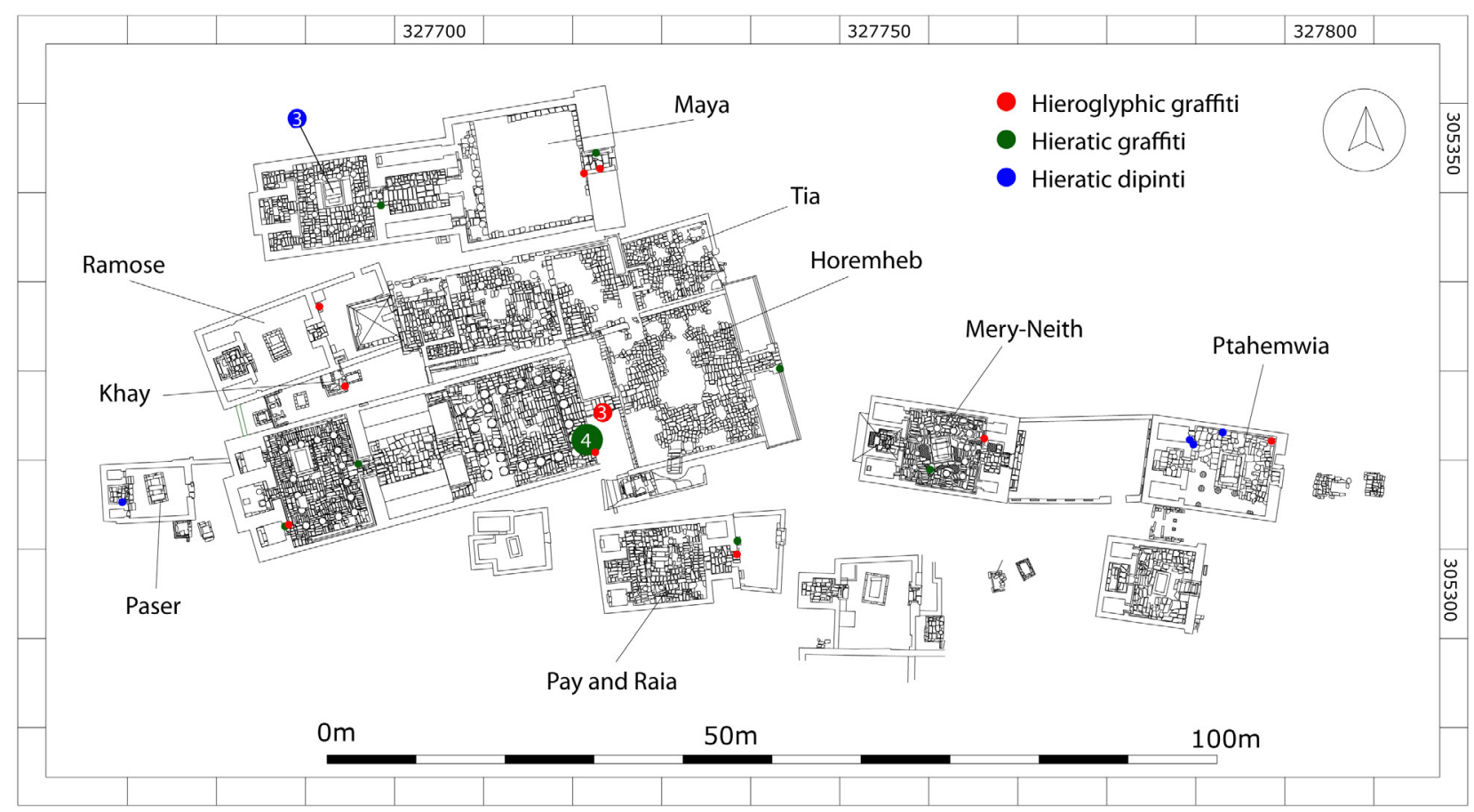

Fig. 38: Distribution of textual graffiti in the Saqqara New Kingdom necropolis, Leiden-Turin concession area (2013). Map by the authors.

doorway may perhaps have been considered a liminal zone par excellence, being a boundary between the realm of the living (profane) and the realm of the dead (sacred). ${ }^{139}$ The courtyard, on the other hand, was a space where people spent time waiting during services in honour of the deceased, ${ }^{140}$ which may have encouraged them to leave a graffito on the wall. In this large open space graffiti would also remain longer in the vision of earthly visitors and thus would have a greater chance of being read or seen by anyone entering the tomb. ${ }^{141}$ In contrast, the less spacious side-chapels may have functioned as storage quarters and been less accessible. As evidenced by the tomb of Ptahemwia, at least some chapels, 


\begin{tabular}{|lllll|}
\hline Site & Total & Textual & Figural & $\begin{array}{l}\text { Ratio of image } \\
\text { to text }\end{array}$ \\
\hline Horemheb & 76 & 14 & 62 & 4.43 \\
Khay & 1 & 1 & 0 & 0 \\
Maya and Meryt & 60 & 9 & 51 & 5.67 \\
Mery-Neith & 9 & 2 & 7 & 3.50 \\
Paset & 3 & 2 & 1 & 0.50 \\
Pay and Raia & 12 & 5 & 7 & 1.40 \\
Ptahemwia & 48 & 4 & 44 & 11.00 \\
Ramose & 5 & 1 & 4 & 4.00 \\
Tia and Tia & 10 & 1 & 9 & 9.00 \\
\hline Hibis Temple* & 269 & 146 & 123 & 0.84 \\
Isis temple Aswan* & 314 & 135 & 179 & 1.32 \\
Khonsu temple** & 334 & 230 & 104 & 0.45 \\
\hline
\end{tabular}

Table 1: Overview of the ratio of figural vis-à-vis textual graffiti per tomb, with some temples added for comparison. ${ }^{*}$ Graffiti described as "modern" have not been taken into consideration. ${ }^{* *}$ Figural graffiti with accompanying inscriptions have been counted as written graffiti. Figural graffiti forming composite scenes have been counted as a single graffito. Where similar motifs were added together without forming a composite scene, they have been counted individually.

at a later stage, received subsidiary burials, restricting access and by extension the opportunity to leave graffiti. In contrast to figural graffiti, entrances do not appear to have been spaces of particular interest for leaving textual graffiti (Fig. 38). Most textual graffiti $(29.2 \%)$ are located in courtyards, particularly in the second courtyards of the larger tombs, where they are inscribed in the vicinity of doorways and on stelae. There is a remarkable clustering of textual graffiti on the second pylon of the tomb of Horemheb, which suggests that graffitists were not only inspired by notions of space but also by already present graffiti. The same has been observed elsewhere in the Saqqara necropolis. For example, in Djoser's South Chapel graffitists attack each other, not by damaging each other's graffiti but by strongly commenting upon them. ${ }^{142}$ A rude graffito in Userkaf's pyramid complex can potentially also be interpreted as a comment to an existing text. ${ }^{143}$

When the ratio of textual to figural graffiti is compared by tomb (Table 1; Fig. 39) it becomes clear that visitors to the tombs of Horemheb and Maya depended more on the written word than those to other tombs. ${ }^{144}$ The tomb of the deified pharaoh had become a pilgrimage destination during the Nineteenth Dynasty, and as such may have attracted a greater number of elite or educated visitors than the surrounding tombs. When the ratio between textual and figural graffiti is compared with contexts outside of the funerary sphere another interesting point is revealed. Most notably, in temple contexts the emphasis on the written word is much higher still than in the tombs of Horemheb and Maya.

However, based on these varied locations, it should not be surprising that a highly variable picture emerges in terms of the relative emphasis on textual or figural graffiti. Such variations ultimately reflect different sets of people frequenting different kinds of monuments for different reasons. As suggested by Navrátilová, ${ }^{145}$ diversity and representation are key words for describing ancient Egyptian graffiti, but this diversity can only be properly assessed and made visible if textual and figural graffiti are investigated as part of an integrated approach. Only then is it possible to consider the full range of human activities and social forces that resulted in their production.

Finally, it is possible in some cases to reconstruct the position that a graffitist assumed while making a 


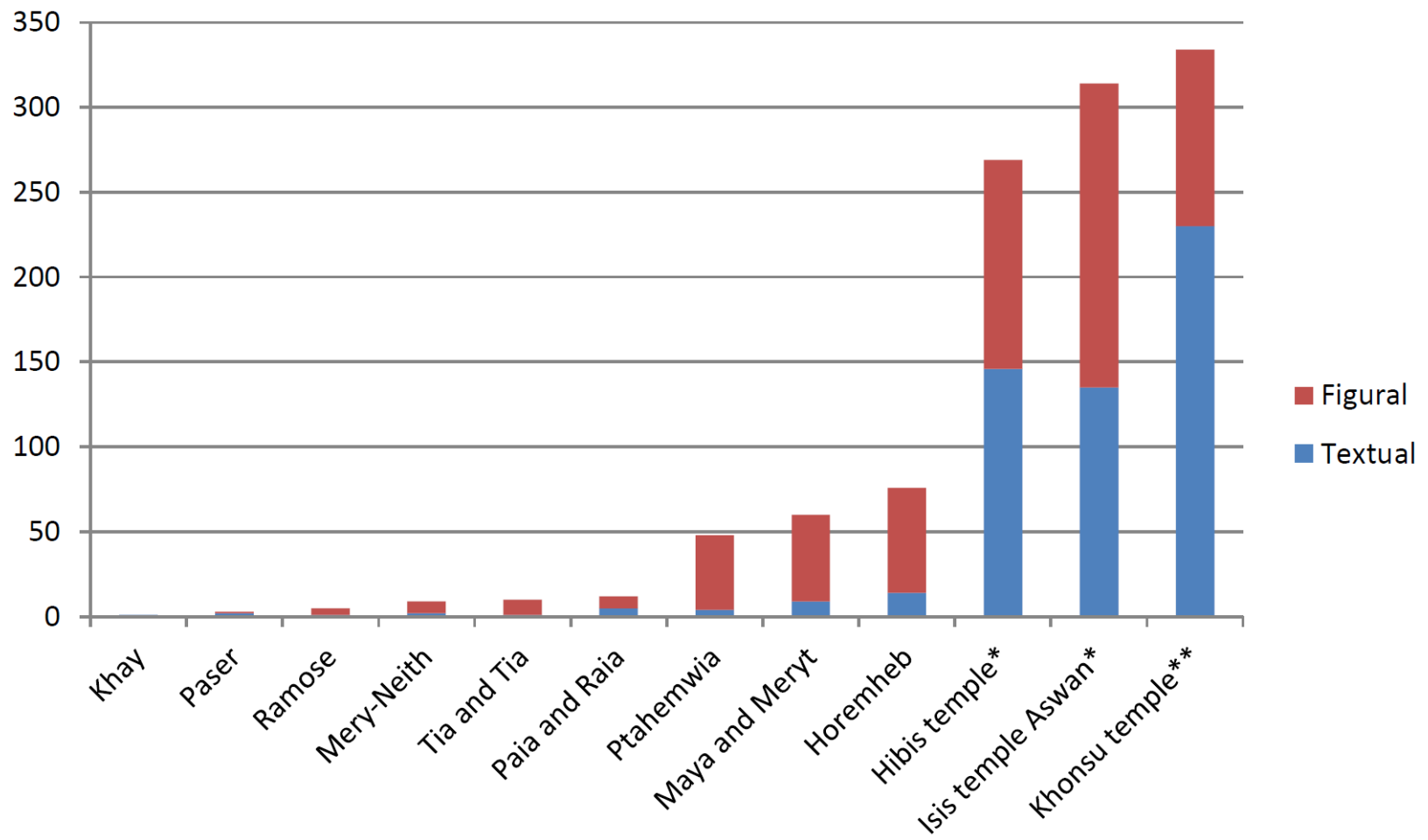

Fig. 39: Distribution of textual graffiti in the Saqqara New Kingdom necropolis, Leiden-Turin concession area. Map by the authors.

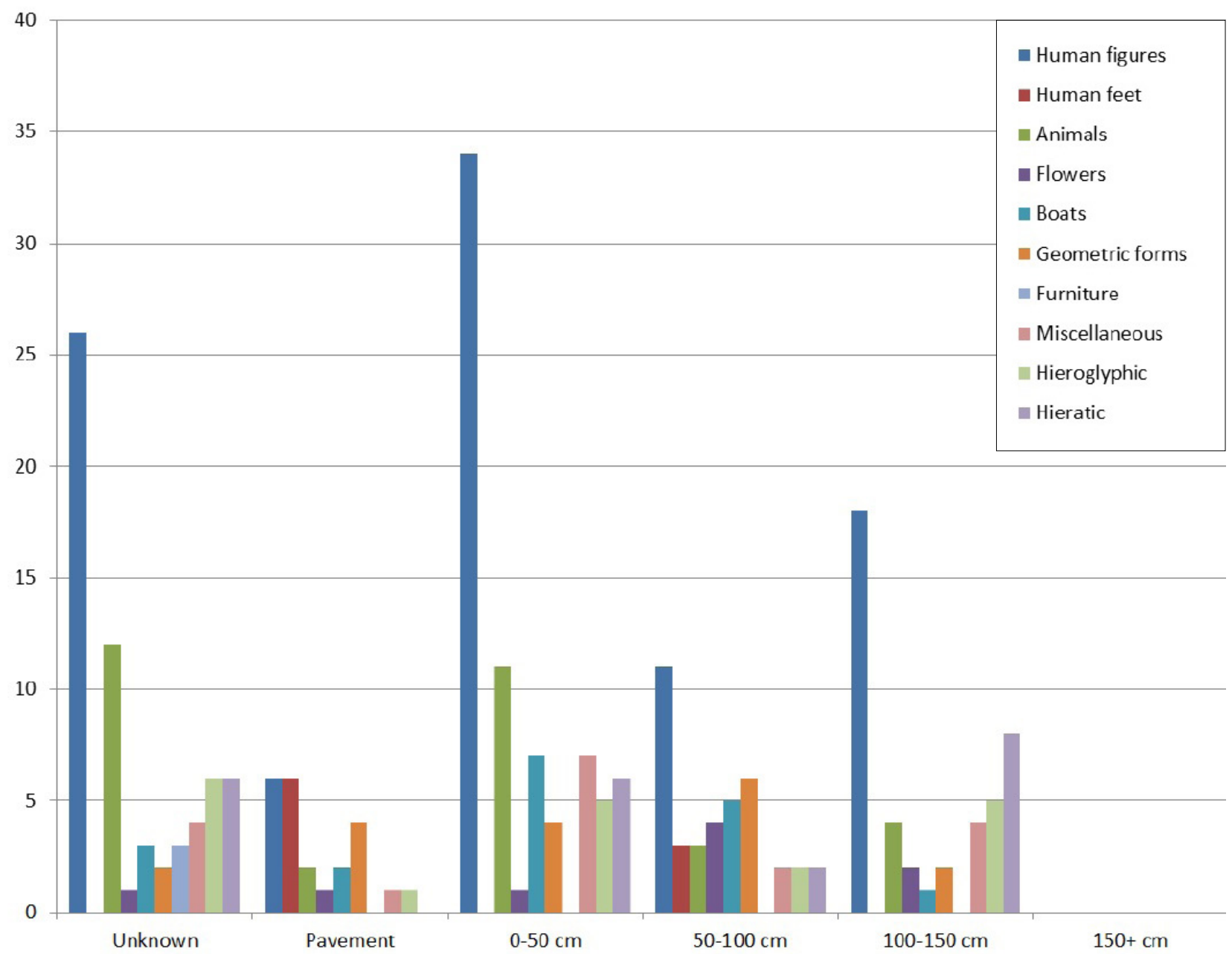

Fig. 40: Distribution of graffiti over wall sections in the New Kingdom necropolis at Saqqara. Graph by the authors. 
graffito by assessing the distance between the graffito and the original pavement level. For the present study, walls were divided into segments: $0-50 \mathrm{~cm}$; 50-100 cm; 100-150 cm; 150+ cm (Fig. 40). The majority (31.7\%) of figural graffiti were added on the walls' lower sections, which indicates that graffitists most commonly assumed a seated or crouching position while making a figural graffito. This tendency differs from that observed for textual graffiti, where a slight preference for a standing pose was observed.

\section{Conclusion}

Although textual graffiti are common in the Saqqara New Kingdom necropolis ( $\mathrm{n}=41$ ), they are in a vast minority when compared with figural graffiti without associated text $(n=202)$. It is clear, therefore, that by considering only the written evidence, previous studies of ancient Egyptian graffiti in the Saqqara necropolis have captured only part of a much larger phenomenon of graffiti making. The strong emphasis on written graffiti may also have introduced a significant social bias into their results as the written evidence necessarily restricts the range of graffitists to the literate members of the elite and sub-elite. The execution and content of figural graffiti, on the other hand, potentially hint at wider engagement and may allow access to a broader section of ancient Egyptian society. In keeping with the imagistic principle of Egyptian magic, figural graffiti would have been directly associated with an individual or an object in much the same way as an inscribed name or text and they would have been just as powerful magically speaking, setting the strict need for literacy aside. As such, figural graffiti in tombs may represent a meaningful and directly personal interaction between the graffitist, the deceased, and the funerary gods that did not require the mediations of a trained priest or scribe. Admittedly, the interpretation of figural graffiti is challenging and subjective. However, it is often possible to isolate reasonable interpretations by taking a close look at the context of the graffiti and by drawing upon the meaning and significance of similar motifs and symbols on other artefacts. As argued in this contribution, one should be cautious against drawing solid boundaries between textual and figural graffiti as the two are not necessarily disarticulated conceptually and may have been created with comparable intent. ${ }^{146}$ In some cases the choice for one medium over another may have had to do more with the limited literacy rates and the problems of dissemination of information carried in word and image than with different motivations for the production of a graffito. It has been shown here that figural graffiti in tombs are rich in magical and mythological symbolism and can often be interpreted as figural prayers in their own right. Such figural graffiti, like many of their written counterparts, were intended to reconstitute links between the living and the deceased, secure benefits and blessings for the graffitist, or protect and beatify the deceased in the afterlife. As such, both textual and figural graffiti can be seen as part of the social and ritual interaction of which Egyptians wished to be part after their death and burial, ${ }^{147}$ and as supplements to the more formal accoutrements of self-presentation and religious expression in the mortuary sphere, such as statues and stelae, many of which were expensive and exclusive. In contrast, graffiti could be created by individuals at no or very little financial cost to themselves, making it a form of representation and commemoration that was within the means of the lower echelons of Egyptian society. As indicated by the presence of secondary burials, people with modest means had access to the Saqqara necropolis, at least during the late New Kingdom, and it seems likely, therefore, that visits to the necropolis were part of the lifeways of a broad range of people. The artefacts found in these secondary burials, particularly amulets, suggest that the people interred in them would have been familiar with the meaning and significance of common religious symbols, such as the wedjat eye. They could have drawn on this knowledge to encode and decode messages through figural graffiti and use them to guide behaviour towards particular goals. Of course, there is little doubt that the scribal elite and sub-elite also produced figural graffiti, as people may choose to draw instead of write (or use a combination of the two) for a variety of reasons. However, this interpretation must not stand at the beginning but at the end of a comprehensive contextual analysis. 


\section{Notes}

${ }^{1}$ W. Paul van Pelt (Trinity Hall, University of Cambridge, Cambridge, UK) and Nico Staring (Macquarie University, Sydney, Australia; Leiden University, $\mathrm{NL}$; research conducted with financial support of a Vidi Talent Scheme research grant awarded by the Netherlands Organisation for Scientific Research [NWO], dossier no 016.Vidi.174.032 for the project, "The Walking Dead at Saqqara: The Making of a Cultural Geography"). The authors would like to thank Geoffrey Martin, Maarten Raven, Boyo Ockinga, Kate Spence, and the two anonymous reviewers of the Rivista del Museo Egizio for their valuable comments on a draft version of this paper. The ideas and opinions expressed in the text are those of the authors. This article was initially prepared and accepted for publication in 2014 . However, due to several delays in the publication process, the authors decided to retract the article and submit an updated version of it for publication in the Rivista. At the time, the archaeological mission to the New Kingdom necropolis at Saqqara was a joint enterprise of the Rijksmuseum van Oudheden in Leiden and Leiden University. In 2015, the Museo Egizio in Turin joined the mission.

${ }^{2}$ Cruz-Uribe, in Wendrich (ed.), UCLA Encyclopedia of Egyptology, 2008, http://escholarship.org/uc/ item/7v92z43m.

${ }^{3}$ In recent years, there has been a marked increase in the number of projects focusing on the documentation of graffiti on specific monuments or in specific locations (such as necropolises), and conferences dealing with graffiti-making in antiquity (most recently: "Clamour from the Past: Graffiti, Rock Inscriptions and Secondary Epigraphy from Ancient Egypt", Institut français d'archéologie Orientale and Sorbonne Université, 15-17 June 2019, Cairo). This has resulted in a growing number of publications on the subject. The following references (and those cited elsewhere in this article) represent just a small selection: Fábián, in Luft (ed.), The Intellectual Heritage of Egypt, 1992, pp. 137-56; Raven, in OMRO 79 (1999), pp. 81-102; Jacquet-Gordon, Graffiti on the Temple Roof, 2003; Cruz-Uribe, Graffiti from the Temple Precinct, 2008; Dijkstra, Figural and Textual Graffiti, 2012; Di Cerbo and Jasnow, in Dorman and Bryan (eds.), Perspectives on Ptolemaic Thebes, 2013, pp. 35-51; Ragazzoli, in SAK 42 (2013), pp. 269-325; Iskander and Goelet, The Temple of Rameses II in Abydos, 2015; Ragazzoli, La grotte des scribes, 2017; Davies, Prada and Woodhouse, EA 53 (2018), pp. 4-12; Ragazzoli et al. (eds.), Scribbling Through History, 2018.

${ }^{4}$ E.g. Peden, The Graffiti of Pharaonic Egypt, 2001; Navrátilová, in Bareš et al. (eds.), Egypt in Transition, 2010, pp. 305-32; Navrátilová, Visitors' Graffiti, 2007; Navrátilová, Visitors' Graffiti, 2015; Darnell, in Allen and Shaw (eds.), Oxford Handbook of Egyptology (in press).

${ }^{5}$ Compare, for example, recent work carried out in the temple of Karnak: Salvador, in Ullmann (ed.), 10. Ägyptologische Tempeltagung, 2016, pp. 111-28.

${ }^{6}$ Cf. Turner, in IJNA 35/2 (2006), pp. 253-73. The interpretation of pictorial graffiti depends, to a much greater extent than the interpretation of written graffiti, on reasoning by analogy and context. What is there to be interpreted is only a field of iconic likenesses, in which there are only implicit relationships between things. For that reason the interpreter must supply most of the cognitive background of a pictorial graffito him- or herself, including its conceptual content and its underlying motivations. As a result, pictorial graffiti are often intrinsically ambiguous and lend themselves to a wide array of different interpretations.

${ }^{7}$ Cf. Turner, in IJNA 35/2 (2006), pp. 253-73.

${ }^{8}$ Baines in MAN N.S. 18 (1983), pp. 572-99; Baines and Eyre, in Baines (ed.), Visual and Written Culture, 2007, p. 67.

${ }^{9}$ Helck, in Edel et al., Das Sonnenheiligtum, 1969, pp. 115-21; Morenz, in Tait (ed.), 'Never Had the Like Occurred', pp. 101-13; Navrátilová, in Bareš et al. (eds.), Egypt in Transition, 2010, pp. 305-32; Navrátilová, Visitors' Graffiti, 2007; Navrátilová, Visitors' Graffiti, 2015, pp. 268-72, 277-79; Verhoeven, in Kahl et al. (eds.), Seven Seasons at Asyut, 2012, pp. 47-58; Ragazzoli, in SAK 42 (2013), pp. 269-25. There are many possible interpretations of the word literacy, but it is important to recognise that there was a continuum of literacy levels (e.g. Der Manuelian, in Teeter and Larson [eds.], Gold of Praise, 1999, pp. 285-98; Quirke, Egyptian Literature 1800 BC, 2004, pp. 37-38), ranging from functional to scribal (Keegan, in Baird and Taylor [eds.], Ancient Graffiti in Context, 2011, p. 173).

${ }^{10}$ Málek, in Lloyd (ed.), Studies in Pharaonic Religion, 1992, p. 67; Peden, Graffiti of Pharaonic Egypt, 2001, p. 96; Baines and Eyre, in Baines (ed.), Visual and Written Culture, 2007, p. 72 n. 6; Navrátilová, in Bareš et al. (eds.), Egypt in Transition, 2010, p. 329; Navrátilová, Visitors' Graffiti, 2007, p. 16; Navrátilová, Visitors' Graffiti, 2015, pp. 12-13; Verhoeven, in Kahl et al. (eds.), Seven Seasons at Asyut, 2012, p. 57.

${ }^{11}$ Arguably anyone of able mind and body has the capacity to draw, regardless of their gender, social status, civic position, economic conditions, or literacy competency.

${ }^{12}$ Conversely, one can also consider the situation from the perspective of the observer. While the reading of names and texts was restricted to a small, albeit influential section of society, a much larger number of individuals would have been able to interpret, negotiate, and make meaning from information presented in the form of an image. Cf. a project aimed at an integrated study of both images and texts in rock art on Sehel Island in the south of Egypt: Bormann, Archäologie in Ägypten 4 (2016), pp. 32-33.

${ }^{13}$ While monumental tombs and their fixtures and fittings present the scholar with a wealth of objects, they mainly reflect the hopes, ambitions, and customs of the very richest members of Egyptian society.

${ }^{14}$ This survey was carried out by the authors in 2007 when the tomb of the late Eighteenth Dynasty Royal Butler, Ptahemwia, was excavated. The graffiti recorded in the tomb of Ptahemwia will be published 
in: Raven et al., Ptahemwia and Sethnakht, in press.

${ }^{15}$ Ideally this analysis would have included the entire Saqqara necropolis, but inevitably such an undertaking draws largely upon fieldwork and at present the number of publications of tombs in the area with explicit attention to graffiti is still very limited. A team of archaeologists from Cairo University unearthed around 40 tombs and burialpits belonging to the New Kingdom in the area immediately north of the Leiden-Turin concession area, but their preliminary reports make no mention of any graffiti (Tawfik, MDAIK 47 [1991], pp. 403-9; El-Aguizy, BEM 4 [2007], pp. 41-50). Gohary also does not mention any graffiti in his publications of the tombs in this area (Gohary, BIFAO, 91 [1991], pp. 191-94; Gohary, BIFAO 91 [1991], pp. 195-205; Gohary, The Twin Tomb Chapel, 2009). Of the New Kingdom tombs at the Abwab el-Qotat/Bubasteion only the tombs of Thutmosis (I.19) and Maia (I.20) have been fully published (Zivie, La tombe de Maïa, 2009; Zivie, La tombe de Thoutmes, 2013), but here too no graffiti are mentioned. However, that graffiti exist in this cemetery is clear from a published photograph showing a jackal head graffito in the tomb of AperEl/Aperia (I.1) (Zivie, in Zivie [ed.], Memphis et ses nécropoles, 1988, pl. 14). Ockinga (Amenemone the Chief Goldsmith, 2004; Id., in Bárta et al. [eds.], Abusir and Saqqara, 2011, pp. 119-38; Id. in Evans [ed.], Ancient Memphis, 2012, pp. 371-95), who excavated in the northern part of the Teti cemetery, does not mention any graffiti in any of the New Kingdom tombs he excavated. However, one should be cautious in concluding from these reports that no graffiti are present in these buildings. It is often easy to pass over graffiti as many of them are only shallowly incised and nearly invisible in direct sunlight. Aside from monuments still in situ, a few reliefs from Saqqara in museum collections contain graffiti. These are a relief from the chapel of Merymery (Leiden AP. 6; Boeser, Beschrijving, 1911, pl. 18), Djed-pillars of Ptahmose (Leiden AP. 51; Boeser, Beschrijving, 1911, p. 8, pls. 26-29; Staring, in Horn et al., 2011, pp. 152-54, figs. 5-8), a stela of Amenhotep-Huy and his son Ipy (Florence 2567; Pasquali and Gessler-Löhr, BIFAO 111 [2011], fig. 3), reliefs of the royal butler Wenefdjedsen (Boston MFA 24.981; Dunham, JEA 21 [1935], pp. 149-50, pl. 18; Martin, Corpus of Reliefs, 1987, pl. 33; originally from the Teti Pyramid Cemetery), and a relief of an anonymous official (BM EA 69667; Martin, Corpus of Reliefs, 1987, pl. 14.39). Because comparative material is still relatively scarce, the efforts at interpretation offered in this contribution may at times appear to contain a considerable amount of conjecture against a small quantum of fact. However, the main aim is to stimulate discussion and demonstrate that at the heart of the matter are questions of great significance, which deserve to be the focus of renewed and detailed research.

${ }^{16}$ These should not be seen as strict and imposing categories.

${ }^{17}$ For another definition of the term graffiti, underlining its complexity; see Cruz-Uribe, Hibis Temple Project,
2008, pp. 197-225. For a critical discussion of the term graffiti as it is applied in Egyptology, see Navrátilová, in Bareš, Egypt in Transition, 2010, pp. 306-07.

${ }^{18}$ The fact that graffiti are unofficial markings does not automatically imply a secondary application. Several types of graffiti may just as well have been executed before the official tomb decoration was applied or even before the stone's surface had been fully prepared (cf. Navrátilová, in Bareš, Egypt in Transition, 2010, pp. 305-32). For example, in the temple of Ptah at Karnak, a zone of graffiti was later formalised through the addition of official temple decoration (Frood, in Ragavan [ed.], Heaven on Earth, 2013, p. 296).

${ }^{19}$ For the observation that graffiti were a socially acceptable practice in antiquity, see e.g. Fleming, Graffiti and the Writing Arts, 2001; Baird and Taylor, in Baird and Taylor (eds.), Ancient Graffiti in Context, 2011, pp. 1-19; Keegan, Graffiti in Antiquity, 2014; Ragazzoli et al., in Ragazzoli et al. (eds.), Scribbling through History, 2018, pp. 1-15.

${ }^{20}$ Ritner, in Redford (ed.), The Oxford Encyclopedia of Ancient Egypt, 2001, pp. 321-26.

${ }^{21}$ The idea that the memory of an individual could be kept alive through the written word is made explicit in the Tale of the Eloquent Peasant (B1, 308-10): “When he is buried, and earth envelops him, his name is not effaced on earth and he is remembered on account of the goodness on earth. This is the norm of the god's word [=the hieroglyphic script]".

${ }^{22}$ Navrátilová, Visitors' Graffiti, 2007, p. 140; Navrátilová, Visitors' Graffiti, 2015, pp. 275-77.

${ }^{23}$ Peden, Graffiti of Pharaonic Egypt, 2001, p. 61.

${ }^{24}$ Martin, Tomb of Maya and Meryt, I, 2012, pls. 60.29, 61.30 .

${ }^{25}$ Martin, Memphite Tomb of Horemheb, I, 1989, pp. 107, 159, pl. 149. Martin concludes that these foot graffiti were "undoubtedly executed in the Romano-Coptic era". However, Dijkstra, Syene, I, 2012, p. 43, with n. 211 , has shown that such graffiti are not restricted to Late Antiquity, but appear as early as the old Kingdom and are also found in New Kingdom temples (cf. Castiglione, AAASH 22 [1970], pp. 102-29). The location of many of these graffiti on the roofs of temples indicates they were left by people who had access to these areas (i.e. temple personnel). Some examples are also found outside the temple building proper, and thus could have been left by other types of visitors (Dijkstra, Syene, I, pp. 44-46).

${ }^{26}$ Jacquet-Gordon, Graffiti on the Temple Roof, 2003, p. 5.

${ }^{27}$ Jacquet-Gordon, Graffiti on the Temple Roof, 2003, p. 5; Cruz-Uribe, in Wendrich (ed.), UCLA Encyclopedia of Egyptology, 2008, p. 203, http://escholarship.org/uc/ item/7v92z43m; Dijkstra, Syene, I, 2012, pp. 43-46.

${ }^{28}$ Cf. Plesch, JMEMS 32/1 (2002), p. 182.

${ }^{29}$ Meskell, Private Life, 2002, pp. 184-85; Harrington, Living with the Dead, 2012, pp. 86-94.

${ }^{30}$ Cf. Plesch, JMEMS 32/1 (2002), p. 183.

${ }^{31}$ Martin, Tomb of Maya and Meryt, I, 2012, pp. 19-20, pls. 12-13.

${ }^{32}$ Martin, Tomb of Tia and Tia, 1997, p. 25, pls. 37, 144, 146-47. 
${ }^{33}$ At Thebes the practice of adding signatures to figures belonging to the original tomb decoration is attested, amongst others, in the tomb-chapels of Ameneminet (TT277), Nakht (TT161), Senet and Antefoker (TT60), and Neferronpe (TT178) (Den Doncker, in Kóthay [ed.], Art and Society, 2012, pp. 24-25; Ragazzoli, SAK 42 [2013], pp. 269-325). However, in these cases the graffitists invariably adopt the generic title "scribe" with no other specification or any mention of a specific institution. According to Ragazzoli, SAK 42 (2013), p. 293, such titles were intended to indicate a certain status, not a function, and were used to create a collective space connected with a collective, scribal identity. This does not appear to have been the underlying motivation for the signatures in the tombs of Maya and Tia, because the graffitists either do not identify themselves as scribes or are scribes that are affiliated with a specific institution.

${ }^{34}$ Scholars tend to assume that emotional motivation or content can only be identified reliably for ancient cultures through written records. While such an approach is rightly cautious, it risks overlooking humanly important phenomena and some of the very personal meanings and motivations that visits to the necropolis may have had for people. To grieve over the loss of a loved one is arguably a natural phenomenon that is experienced by people from all classes and cultures (Bowlby, Attachment and Loss, I, 1969; Bowlby, Attachment and Loss, III, 1980; Brown, Human Universals, 1991; Pinker, The Blank Slate, 2002, p. 55). Pictorial and written evidence show that grief was experienced and expressed openly in ancient Egypt, despite sanguine hopes for a long and prosperous existence for the deceased in the afterlife. Bereavement is a very complex phenomenon and as within each cultural group grief responses in ancient Egypt are likely to have varied in each case and per individual depending on the circumstances surrounding each death and important variables such as the age and personality of the mourner, the age and personality of the deceased, nuclear and extended family perceptions and support, prior experiences with death and loss, etc. (cf. also Meskell, Archaeologies of Social Life, 1999, pp. 130-31). To deny or grant someone the desire to visit tombs to be close to the deceased and to leave mementoes of such visits only on the basis of their ability to read or write would be to adopt a hyper-intellectual view of the Egyptian past from which the human element has been almost entirely removed.

${ }^{35}$ Cf. Den Doncker, in Kóthay (ed.), Art and Society, 2012, pp. 24-25; Ragazzoli, SAK 42 (2013), p. 288.

${ }^{36}$ Martin, Tomb of Maya and Meryt, I, 2012, p. 53, pl. 59.

${ }^{37}$ De Vries, Met het oog op het laatste oordeel, 2014.

${ }^{38}$ Esquieu, in De la Roncière (ed.), Histoire et société, 1992, p. 124; Fuchs, Warum steht Herrmann Kopf?, 2009, p. 11.

${ }^{39}$ Examples of pictorial devotional graffiti possibly date back as far as the Old Kingdom. See, for example, Kanawati and Abder-Raziq, Tomb of Hesi, 1999, p. 27, pls. 11, 15, 53; and Altenmüller, Die Wanddarstellungen im Grab des Mehu, 1998, p. 90, pl. 5.
${ }^{40}$ The belief in the magical effects produced by images was so deep that hieroglyphic signs representing dangerous beasts of prey and serpents were sometimes intentionally damaged in the underground chambers of Old Kingdom pyramids. A serpent or lion separated in two pieces could no longer come to life and threaten the King in his burial chamber. Similarly, sculptures and wall paintings sometimes show the deliberate hacking out of the hands, feet, nose, mouth, and eyes of the subject(s) in order to render them magically useless (cf. Meskell, Object Worlds in Ancient Egypt, 2004, pp. 7-9).

${ }^{41}$ Martin, Tomb of Tia and Tia, 1997, p. 45, pl. 93.324; Martin, Tomb of Maya and Meryt, I, 2012, pl. 61.27.

${ }^{42}$ For similar graffiti in the tomb of Kheruef (TT192), see The Epigraphic Survey, Tomb of Kheruef, pls. 35-38, 71; the tomb of Senet and Antefiqer at Thebes (TT60), see Ragazzoli, SAK 42 (2013), pp. 287-88, 307 [G]. Similar adoration graffiti have also been documented in wadis in the Western Desert: Dorn, in Haring et al. (eds.), The Workman's Progress, 2014, pp. 65-67, figs. 5-6.

${ }^{43}$ Martin, Tomb of Maya and Meryt, I, 2012, pl. 60.14-15.

${ }^{44}$ That the subterranean area of the tomb of Maya and Meryt may have been partly accessible prior to Maya's death is suggested by the presence of rock-cut stelae (Chambers $\mathrm{G}$ and $\mathrm{E}$ ) and offering tables (Corridor J) (Raven, Tomb of Maya and Meryt, II, 2001, p. 8; Martin 2012, p. 41, 58, pls. 38, 69). Interestingly, one of these stelae depicts a priest in front of a seated figure of Meryt only (Martin, Tomb of Maya and Meryt, I, 2012, p. 41, pl. 38; Raven, Tomb of Maya and Meryt, II, 2001, p. 8).

${ }^{45}$ It is unlikely that these graffiti should be interpreted as positioning marks, intended to ensure the correct delivery and positioning of the limestone casing of the subterranean corridors. Positioning marks normally carry information such as the numbers of the courses, indications of placements (above, below, etc.), and the number of the stone in the course (Arnold, Building in Egypt, 1991, p. 20). Such information is completely lacking in this case. The two graffiti would also be unusually ornate and complex for setting marks (cf. for example Arnold, Building in Egypt, 1991, p. 21, fig. 1.21).

${ }^{46}$ E.g. Firth and Gunn, Teti Pyramid Cemeteries, 1926; Quibell and Hayter, Teti Pyramid, North Side, 1927; Goneim, Horus Sekhemkhet, 1957, pp. 23-29; Kanawati et al., Excavations at Saqqara, 1984, pp. 59-80; Kanawati and El-Khouly, Excavation at Saqqara, II, 1988, pp. 42-48; Raven, Tomb of Iurudef, 1991; Sowada et al., Teti Cemetery at Saqqara IV, 1999; Raven et al., JEOL 40 (2006-7), pp. 34-37; Raven and Van Walsem, Memphite Tomb of Horemheb V, 2011, pp. 35-47.

${ }^{47}$ It is important to point out that ritual activities are not necessarily highly elaborate ceremonies. A ritual act can be as simple as making the sign of the cross upon entering a church or uttering a prayer for a safe journey.

${ }^{48}$ Muir, Ritual in Early Modern Europe, 1997, p. 6.

${ }^{49}$ Helck, ZDMG 102 (1952), p. 40. 
${ }^{50}$ This observation illustrates that not all written graffiti are as individualistic as some scholars argue (e.g. Peden, Graffiti of Pharaonic Egypt, 2001, xxi). The same holds true for certain groups of pictorial graffiti, including graffiti that replicate already present decorations and graffiti that adhere to otherwise conventional patterns and motifs, both in form and content.

${ }^{51}$ Fischer-Elfert, in Tait (ed.), 'Never Had the Like Occurred', 2003, p. 132; Kahl, GM 211 (2006), pp. 25-29; also Verhoeven, in Kahl et al. (eds.), Seven Seasons at Asyut, 2012, p. 57; Verhoeven, in Moers et al. (eds.), Dating Egyptian Literary Texts, 2013, pp. 139-58. The modern term "school", which implies a rather formal and institutionalised setting and curriculum, does not accurately reflect the way in which visitors' inscriptions or formulas were being taught. See: Ragazzoli, NeHeT 4 (2016), pp. 65-76.

${ }^{52}$ Navrátilová, Visitors' Graffiti, 2007, pp. 131-32, Navrátilová, in Bareš et al. (eds.), Egypt in Transition, 2010, pp. 305-32; Navrátilová, Visitors' Graffiti, 2015, pp. 254-56. On the Address to the Living in general, see Desclaux, Les appels aux passants ; Desclaux, BIFAO 117 (2017), pp. 161-202.

${ }^{53}$ Müller, in Helck and Otto (eds.), Lexikon der Ägyptologie, I, 1975, p. 293; Salvador, in Accetta et al. (eds.), Current Research in Egyptology 2013, 2014, pp. 153-54.

${ }^{54}$ Cf. Frood, in Ragavan (ed.), Heaven on Earth, 2013, pp. 289-90.

${ }^{55}$ Graefe, in Helck and Westendorf (eds.), Lexikon der Ägyptologie, VI, 1986, p. 863; Evans, JEA 97 (2011), pp. 103-15.

${ }^{56}$ This practice may also have been connected with the use of the western chapels for mass burial, including a large number of children and adolescents (cf. Raven et al., JEOL 40 [2006-7], p. 28).

${ }^{57}$ For example, in the Valley of the Kings tombs were sealed with images of Anubis to protect the dead against harmful forces. In his mortuary temple at Thebes pharaoh Amenhotep III erected large statues of Anubis protecting an image of the king between its forepaws (Jaritz, MDAIK 48 [1992], p. 77). Two Ramesside (thus later added) limestone plinths in the tomb of Horemheb in Saqqara, positioned on either side of the doorway at the west end of the statue room, once had figures in the round of a recumbent Anubis (Martin, Memphite Tomb of Horemheb, I, 1989, pp. 70-72, pls. 68-71). Limestone statues of Anubis have furthermore been found in the vicinity of the Leiden-Turin concession area (Munro, in Zivie [ed.], Memphis et ses nécropoles, 1988, pl. 6: dedicated by Nefermes and Neferrenpet) and at the Bubasteion (Late Period statuettes, e.g. Jeffreys and Smith, Anubieion at Saqqara, I, 1988, pl. 26a; Manchester Museum acc.no. 11498). In the post-New Kingdom levels of the Teti Pyramid North cemetery, mummified canines (dogs) were found in association with human burials. This led the excavators to interpret these dogs as theriomorphic manifestations of Anubis, the dogs, practically speaking, being amuletic animal mummies (Hartley et al., in Bárta et al. [eds.], Abusir and Saqqara,
2011, pp. 27-29). Jackal-shaped amulets were also worn by the dead to propitiate the protective powers of Anubis and Wepwawet (Andrews, Amulets of Ancient Egypt, 1994, pp. 46-47).

${ }^{58}$ Zivie, in Zivie (ed.), Memphis et ses nécropoles, 1988, pl. 14.

${ }^{59}$ Ursula Verhoeven, personal communication.

${ }^{60}$ These canines can be interpreted as Anubis or Wepwawet. The latter deity is perhaps alluded to in the epithet in front of Horus-Min: $w p(i) w 3 . w t ~ \check{S} m e . w$ Mh.w, "Opener-of-the-ways of Upper and Lower Egypt". See: Staring, in Horn et al. (eds.), Current Research in Egyptology, XI, 2011, pp. 148-50; Staring, in Di BiaseDyson and Donovan (eds.), Cultural Manifestation of Religious Experience, 2017, pp. 251-62.

${ }^{61}$ The resulting alignment of figures is reminiscent of the New Kingdom Salakhana votive stelae from Asyut, dedicated to Wepwawet (Munro, ZÄS 88 [1962], pp. 48-58; DuQuesne, Anubis, Upwawet, and Other Deities, 2007). As opposed to the Salakhana stelae, the jackals on Louvre C8 are not part of the original decoration and are oriented towards Min-Horus.

${ }^{62}$ If these graffiti depicted gods they may have been considered too hallowed to be interfered with.

${ }^{63}$ Martin, Tomb of Maya and Meryt, I, 2012, pl. 59.1.

${ }^{64}$ Faulkner, Ancient Egyptian Book of the Dead, 1985, p. 155.

${ }^{65}$ In the graffito in the tomb of Ptahemwia the graffitist made a mistake in the depiction of the markings around the falcon's eye, curling the "teardrop" mark below the eye instead of the mark to its left. As the wedjat eye was also a hieroglyphic symbol, it is possible that the graffitist was not familiar with writing monumental hieroglyphs.

${ }^{66}$ Pinch, Magic in Ancient Egypt, 1994, p. 110.

${ }^{67}$ Food offerings could also be called the Eye of Horus, for example in Pyramid Texts spell 87a-b. It is also possible that the graffitist had this symbolism in mind and intended the graffito to suffice instead of actual food offerings in the daily ritual.

${ }^{68}$ Andrews, Amulets of Ancient Egypt, 1994, p. 88. Cf. vignette DB chapter 81 (Wiese and Brodbeck, Tutankhamun, the Golden Beyond, 2004, fig. 89); painted on mummy cartonnage (Étienne, Journey to the Afterlife, 2006, fig. 95; Louvre N3661); wooden head of Tutankhamun placed on a lotus from tomb KV 62 (Cairo JE 60723).

${ }^{69}$ Pinch, Magic in Ancient Egypt, 1994, p. 109.

${ }^{70}$ Martin, Tomb of Maya and Meryt, I, 2012, pl. 61.

${ }^{71}$ Two lotuses scratched on the entrance to the tomb (unpublished). There is another depiction of a lotus in the tomb of Horemheb, but there it is part of a graffito of a pilgrim's foot (Martin, Memphite Tomb of Horemheb, I, 1989, p. 159, pl. 149.27). There is also an incised depiction of a lotus on a fragment of a stela or offering table found in the tomb of Horemheb (Schneider, Memphite Tomb of Horemheb, II, 1996, pp. 15-16, pl. 6.52). A pottery ostracon found between the tombs of Horemheb and Iniuia contains a graffito (black pigment) of a lotus (Raven, Pay and Raia, 2005, p. 79, pl. 103.82).

${ }^{72}$ Martin, Three Memphite Officials, 2001, p. 2, fig. 2. 
${ }^{73}$ Raven, Pay and Raia, 2005, p. 36, pls. 54-55; Raven et al., Memphite Tomb of Horemheb, V, 2011, pp. 29-30; Staring, in Horn et al., Current Research in Egyptology, 2011, p. 153, fig. 8; Waseda University, Abusir South, 2006, p. 90, no. 2, pl. 14.1.

${ }^{74}$ Kozloff et al., Egypt's Dazzling Sun, 1992; Quirke and Spencer, British Museum Book of Ancient Egypt, 1992, p. 165, fig. 126.

${ }^{75}$ Stadler, Weiser und Wesir, 2009; Frood, in Ragavan (ed.), Heaven on Earth, 2013, p. 296.

${ }^{76}$ Similar associations presumably underlie the selection of four baboon-like creatures for the protection of the mythical "Lake of Fire" in the Egyptian underworld.

${ }^{77}$ Cf. Andrews, Amulets of Ancient Egypt, 1994, p. 67.

${ }^{78}$ Martin, Memphite Tomb of Horemheb, I, 1989, p. 158, pl. 147.15; Martin, Tomb of Maya and Meryt, I, 2012, pl. 62.38. For a parallel in the Theban necropolis, see e.g. the tomb of Antefiqer (TT60): Ragazzoli, SAK 42 (2013), pp. 314-15 (I).

${ }^{79}$ Cf. De Wit, Le rôle et le sens du lion, 1951.

${ }^{80}$ Altenmüller, Die Apotropaia, 1965, pp. 145-48; Bourriau, Pharaohs and Mortals, 1988, pp. 114-16.

${ }^{81}$ Waitkus, GM 99 (1987), pp. 51-82; Assmann, Das Grab des Amenemope TT 41, 1991, p. 153, pl. 44.

${ }^{82}$ Sternberg, in Helck and Westendorf (eds.), Lexikon der Ägyptologie, V, 1984, p. 324.

${ }^{83}$ Borchardt, Das Grabdenkmal des Königs Sa'hu-Re', 1910, pp. 120-35; Baines, GM 4 (1973), pp. 12-13; Bareš, in Bartá and Krejcí (eds.), Abusir and Saqqara, 2011, pp. 5-9; Navrátilová, Visitors' Graffiti, 2007, pp. 49-54; Navrátilová, Visitors' Graffiti, 2015, pp. 83-95; Wildung, in Brinkmann (ed.), Tod und Leben, 2010, pp. 275-77; Khaled, in Bárta et al. (eds.), Abusir and Saqqara, 2011, pp. 512-17.

${ }^{84}$ Martin, Memphite Tomb of Horemheb, I, 1989, p. 158, pl. 147.

${ }^{85}$ Abitz, Statuetten in Schreinen, 1979; cf. also Davies, The Tomb of Antefoker, 1920, pl. 17.

${ }^{86}$ For a round-topped stela depicting two geese with 24 eggs (no inscriptions), see: Lacau, Stèles du Nouvel Empire, 1909-16, p. 200, pl. 61 (Egyptian Museum, Cairo CG 34155 = JE 36161, provenance: Karnak).

${ }^{87}$ Raven, OMRO 61 (1980), pl. 3.

${ }^{88}$ Stevens, Private Religion at Amarna, 2006, pp. 153-63, similarly suggests that some ostraca from domestic contexts at Amarna may have been used as cult images in the realm of private religion. In tomb contexts, ostraca with depictions of humans, heads, and faces may have had a devotional character. See also Weiss, Religious Practice at Deir el-Medina, pp. 159-60 (votive ostraca as "pictorial acts").

${ }^{89}$ Raven, Pay and Raia, 2005, pl. 103.81.

${ }^{90}$ Martin, Tomb of Tia and Tia, 1997, pl. 105.88.

${ }^{91}$ Raven, Pay and Raia, 2005, pl. 103.82; Schneider, Memphite Tomb of Horemheb, II, 1996, pl. 6.52.

${ }_{92}$ Martin, Tomb of Tia and Tia, 1997, pl. 105.90; Raven, Tomb of Maya and Meryt, II, 2001, pl. 31.34.

${ }^{93}$ Egyptologists typically deal with specific types of artefacts, but symbolism that crosses object boundaries may be vital to understanding how objects were understood and used. It could even be argued that a strict separation between "ritual graffiti" and "ritual ostraca" on the basis of their medium may be more of a modern concept, and is untenable for ancient Egypt.

${ }^{94}$ Also suggestive in this context is a roughly roundtopped ostracon from the tomb of Tia and Tia which essentially duplicates the decoration of a stela (Martin, Tomb of Tia and Tia, 1997, pl. 104.16). It consists of two registers with adoration scenes without any writing. While it is possible to interpret the ostracon as a trial piece, it may also have been considered a crude "stela" in its own right. Unlike formal stelae, it could have been produced at virtually no cost and as such the piece may have mimicked the votive gifts of the better off.

${ }_{95}$ Barta, Aufbau und Bedeutung, 1968, pp. 267, 270-71. The Egyptians believed that their vital life force continued to live after death, and needed to be sustained through renewed daily offerings. The $h t p-$ $d i$-nsw formula served as a safeguard in case real offerings ceased to be made, and its recitation was considered sufficient to provide the deceased with all of the basic amenities, such as food, drink, and clothing. Navrátilová, in Bareš et al. (eds.), Egypt in Transition, 2010, p. 315, and Ragazzoli, SAK 42 (2013), p. 276, mention the presence of $h t p-d i-n s w$ graffiti in Theban funerary monuments.

${ }^{96}$ Censing rites had the ability to breathe vitality into inanimate objects, including offerings, statues, and the body of the deceased. During fumigation the body of the deceased appears to have "inhaled" the breath of the god Osiris in the form of incense. Sharing the god's breath not only rejuvenated but also bestowed godhood onto the deceased. This symbolism is reflected in Egyptian lexicon as the word for incense, $s n \underline{t} r$, literally means "to make divine". The gift-giving nature of fumigation is hinted at by the censer's arm shape, which imitated the drp hieroglyph for "offering" (Wise, Studia Antiqua 7/1 [2009], pp. 67-80).

${ }^{97}$ Raven and Van Walsem, Tomb of Meryneith at Saqqara, 2014, scene [4].

${ }^{98}$ For a similar scene from Saqqara, see Martin, Tombchapels of Paser and Ra'ia, 1985, pls. 20 and 22, scene [5].

${ }^{99}$ Martin, Three Memphite Officials, 2001, p. 13, pls. 8 and 52 .

100 The graffito is also very similar to depictions of the Ritual of the Opening of the Mouth in funerary papyri and tomb paintings, although the pivotal funerary priests are not depicted.

${ }^{101}$ Ship graffiti are very common along the Nile Valley and examples have been found deep inland at sites such as Jebel Tjauti in the Western Desert (Darnell, Theban Desert Road Survey, I, 2002, pp. 19-26 [Gebel Tjauty Rock Inscriptions 2-3]; Darnell, Theban Desert Road Survey, II, 2013) and Rod el-Air in Sinai (Gardiner et al., The Inscriptions of Sinai, I, 1952; Wachsmann, Seagoing Ships and Seamanship, 1998, pp. 30-38). The fact that these graffiti are far removed from the sea and waterways strongly suggests that they had both function and meaning. Graffiti depicting boats have also been documented at quarry sites such as Gebel el-Silsila. Their presence there has been explained in terms of practical aspects as means of transportation 
(Ward, in Pinarello et al. [eds.], Current Research in Egyptology, pp. 69-70).

102 Turner, IJNA 35/2 (2006), p. 261.

${ }^{103}$ The voyage to Abydos to visit the burial place of Osiris was an important religious duty for any Egyptian that symbolised their own resurrection and rebirth (Dodson and Ikram, The Tomb in Ancient Egypt, 2008, p. 123). It was regularly depicted in tombs in connection with other funerary rituals beginning in the Eighteenth Dynasty (Altenmüller, in Helck and Westendorf [eds.], Lexikon der Ägyptologie, I, 1975, pp. 42-47). According to Manniche, City of the Dead, 1987, p. 41, ship models were set up in Theban tombs during one of the annual festivals to help the deceased undertake the journey to Abydos. It is possible that some ship graffiti were made with a similar idea in mind.

${ }^{104}$ Alternatively, they could be prayers for a safe passage on journeys yet to come. Today such prayers may hardly seem necessary for journeys across the calm waters of the Nile, but the current river bears little semblance to its pre-1900 state. Before the construction of the Aswan Dam it was much more dangerous to navigate the river during the low-Nile period for any but the smallest Nile boats as sand banks caused grounding and capsizing (Cooper, The Medieval Nile, 2014, pp. 111-17).

${ }^{105}$ Cf. Dijkstra, Syene, I, 2012, pp. 73-75.

${ }^{106}$ Pusch, in Helck and Westendorf (eds.), Lexikon der Ägyptologie V, 1984, p. 852; Dodson and Ikram, The Tomb in Ancient Egypt, 2008, p. 111.

107 “ Copy from whatever you wish on empty papyrus, in order that my name will be known for the everlasting future ... " (Kuhlmann, MDAIK 29/2 [1973], pp. 209-10).

${ }^{108}$ Raven et al., Memphite Tomb of Horemheb, V, 2011, p. 29.

${ }^{109}$ Of the 12 graffiti of humans in the tomb of Ptahemwia, no less than seven depict royalty. The tomb of Maya and Meryt has three further examples of royal heads, one wearing the blue crown (Martin, Tomb of Maya and Meryt, I, 2012, pls. 59.5 and 61.19). In addition, there is a graffito in this tomb that depicts only the blue crown (Martin, Tomb of Maya and Meryt, I, 2012, pl. 62.35). The tomb of Ramose has one example of a royal head wearing the blue crown (Martin, Three Memphite Officials, 2001, p. 2, fig. 2). The tomb of Horemheb contained a limestone ostracon depicting a king wearing the blue crown with uraeus slaying a foreign foe (Schneider, Memphite Tomb of Horemheb, II, 1996, p. 15, pl. 6.46), and a miniature stela depicting a king with blue crown and uraeus (Schneider, Memphite Tomb of Horemheb, II, 1996, p. 18, pl. 8.62). An additional pottery ostracon with a head with uraeus comes from the tomb of Maya (Raven, Tomb of Maya and Meryt, II, 2001, p. 38, pl. 35.141) and a stone ostracon with a royal head with the blue crown was found in the tomb of Pay (Raven, Pay and Raia, 2005, p. 73, pl. 98.17). This tomb also contained two further pottery ostraca with heads, including royal heads with the blue crown and uraeus (Raven, Pay and Raia, 2005, p. 79, pls. 103.76 and 103.78). A limestone ostracon with a royal figure wearing the blue crown holding an ankh -sign was found south of Horemheb's First Pylon (Raven et al., Memphite Tomb of Horemheb, V, 2011, p. 102 [103]). Another pottery ostracon with a fragmentary depiction of a royal figure with blue crown was found east of Tia's forecourt (Raven et al., Memphite Tomb of Horemheb, V, 2011, p. 104 [109]). The graffiti depicting the king are discussed in Staring, in Haring et al. (eds.), Decoding Signs of Identity, pp. 103-11.

${ }^{110}$ E.g. Iskander and Goelet, Temple of Rameses II in Abydos, 2015, pls. 3.1.31 (A14a), 3.2.8 (B5). Also unpublished graffito of a standing king wearing the blue crown, incised on the undecorated dado of a wall (close to pavement level) in the memorial temple of Ramesses II at Abydos. The lower part of the king's body is roughly incised, while the upper part, head, and right hand are carefully executed. Surrounding the head are another blue crown and part of a human face (Daniel Soliman, personal communication).

${ }^{111}$ Ursula Verhoeven, personal communication.

112 Jacquet-Gordon, Graffiti on the Temple Roof, 2003, graffiti nos. 10, 13, 48, 105, 151, 174, 212, 222, 225 , 226, 301.

${ }^{113}$ When it comes to protective symbols, the notion "the more, the better" seems to have applied. If one symbol gave protection, multiple would furnish even more. For this reason, during the Third Intermediate Period some forms of wedjat amulets consisted of four wedjats instead of one (Andrews, Amulets of Ancient Egypt, 1994, p. 44). Similar motivations may also have prompted the inclusion of six wedjat amulets in the grave of a child at Matmar, which was a far larger number than in any other grave at the site (Goulding, What Did the Poor Take with Them?, 2013, pp. 26-27). The Egyptians considered infants and young children especially vulnerable to evil forces and as such the child in this grave may have required greater protection.

${ }^{114}$ Chauvet, in Bárta et al. (eds.) Abusir and Saqqara, 2011, pp. 296-97. Contemporary sources indicate that the deceased continued after death to interact with their living kin, and could be both benevolent and malevolent. Benevolent spirits of the deceased protected the living, whilst malevolent spirits could be held responsible for a variety of problems, ranging from property disputes to ill health. In certain emergencies the living wrote "Letters to the Dead" (Gardiner and Sethe, Egyptian Letters to the Dead, 1928; Wente, Letters from Ancient Egypt, 1990, pp. 210-19; Harrington, Living with the Dead, 2012, pp. 34-37) to ask the deceased for assistance or to desist from exerting malign influences. Such Letters to the Dead and a range of other evidence suggest that the deceased formed part of the lived experience of many Egyptians and were considered personalities to whom the living reacted pragmatically. Graffiti may have been an additional means to bring the dead and the living in touch and forge linkages between them.

115 This interpretation does not contradict the so-called 'sacralisation' of the tomb in the course of the later New Kingdom. Ockinga (in Dorman and Bryan [eds], Sacred Space and Sacred Function, 2007, p. 139, 
following Assmann, in Strudwick and Taylor [eds.], The Theban Necropolis, 2003, p. 51) argued that in the later New Kingdom the tomb provided the deceased with "a place on earth where he can worship the gods and be close to them". This idea is visually expressed in the tomb architecture at Saqqara through the mimicking of contemporary temple architecture, and overtones relating to the personal veneration of the gods by the deceased are indeed strong in post-Amarna tombs. However, it is important to acknowledge that this new interpretation of the tomb is laid over the function of the tomb as place of commemoration and cult. New Kingdom tombs such as that of Maya and Meryt should, in other words, be interpreted both as a temple for the veneration of the gods by the deceased and a tomb for the commemoration and maintenance of the deceased by the living. This dualism is complementary and mirrored in the decoration scheme of the tomb of Maya and Meryt, where the iconography of the accessible superstructure contains depictions relevant to the offering cult (e.g. butchering scenes, offering bearers, depictions of the deceased in front of offering tables, etc.), while the iconography of the inaccessible substructure is almost completely dedicated to the veneration of the gods by the deceased.

116 There is such an appeal in the tomb of Maya (Frood, Biographical Texts, 2007, pp. 141-43; Martin, Tomb of Maya and Meryt, I, 2012, p. 20) on the south reveal of the tomb pylon, and in the tomb of Tia (Martin, Tomb of Tia and Tia, 1997, p. 22) on the north wall of the inner courtyard. In his appeal Maya addresses "... the people who come and wish to divert themselves in the West and walk about in the District of Eternity ...". As such his appeal was targeted at a general audience, who seemingly visited the Memphite necropolis to invigorate or amuse themselves. Tia, on the other hand, employed a somewhat more restrictive approach and specifically addresses “... all you scribes who are skilled in [reading] hieroglyphs, all you chief priests of the temple of Ptah who will visit this [tomb]... ". Such restricted appeals are sometimes taken as evidence that necropolises were mainly visited by specialists. However, it is important to recognise that the evidence is also compatible with other readings, especially when one considers the physical, social, and psychological variables of the medium of the appeals in addition to and apart from the content they convey. For example, from a purely practical point of view one could seriously doubt the appropriateness of hieroglyphs as a medium to communicate with the illiterate, because it would not be an effective means for the deceased to get their message across, either exactly or approximately. It is possible, therefore, to account for the lack of appeals to the illiterate in reference to the possibilities and restrictions of the medium. At the same time it is important to recognise that the character of the medium can directly influence the nature of the social relations or behaviours that it helps to organise. For instance, it is possible that general appeals were considered too anonymous, and that hieroglyphs were used and specific groups of society invoked to make the appeals more personal. Because of the restricted literacy rates, the use of hieroglyphs may have helped to signify a shared scribal identity or group membership (cf. Ragazzoli, SAK 42 [2013], pp. 269-325) between the addressor and the addressees, with the underlying aim of increasing the affective content of the appeals and the likelihood that addressees would (re)act in desired ways.

${ }^{117}$ Navrátilová, in Bareš et al. (eds.), Egypt in Transition, 2010, pp. 310-11.

${ }^{118}$ Ragazzoli, SAK 42 (2013), p. 271.

${ }^{119}$ Figural graffiti dominate the secondary epigraphy corpora in the Memphite tombs whereas textual graffiti are more common at Thebes. One may note that the visitors' inscriptions in the Theban tombs and Memphite royal complexes are predominantly of an (early) Eighteenth Dynasty date. The graffiti recorded in the Saqqara tombs, on the other hand, date to the late Eighteenth Dynasty and later. This observation could be indicative of different practices in different time periods.

${ }^{120}$ When people communicate they do not just utter their contributions randomly. Rather, they tailor their communicative acts, including the medium for sending or sharing information, to specific addressees - all this with a specific purpose in mind and under specific constraints. There is no doubt that only a small percentage of the ancient Egyptian population could read hieroglyphic texts, and it seems reasonable to postulate that for many Egyptians images would have been a much more accessible means for communicating and interpreting messages across time and space, even if only partially. It is not unthinkable that important messages such as the Address to the Living may have been intentionally communicated across different media to address a heterogeneous audience, thereby increasing the likelihood that they would be noticed, understood, and reacted to by as many people as possible. For example, depictions of desired products being borne by attendants or piled on stands may have been designed to convey similar messages as the textual appeals in a form that could be interpreted more broadly, making them more useful triggers for ritual response including the donation of offerings. Egyptologists tend to explain the combined use of image and text in tombs through magic alone: wall scenes were charged images supplemental to funerary texts and were used as "insurance" in case actual material offerings ceased to be made at the tomb. However, in this as in other instances, "magical" and "rational" treatments may well have been paired, and the two methodologies can be seen as complementary rather than immiscible. Readers who did not understand written text may have been able to interpret images and vice versa (compensation), while addressees who understood both the text and the image may have gotten more out of the combination (for example, perhaps one could make out text passages one did not understand by reference to illustrations) (collaboration). Problems of dissemination of information contained in text 
may also have been overcome in other ways including public recitation. In the tomb of Nefersekheru at Zawiyet Sultan scribes are requested to " repeat the writings so that the illiterate and the workers know what is written on the walls of his tomb " (Osing, Das Grab des Nefersecheru, 1992, pp. 43, 52; see also Den Doncker, in: K.A. Kóthay [ed.], Art and Society, 2012, p. 23). The fact that Nefersekheru specifically mentions the illiterate in his inscription provides a strong argument for their presence in this necropolis.

${ }^{121}$ Pinch, Magic in Ancient Egypt, 1994, p. 105.

${ }^{122}$ It is important to emphasise this point, as the knowledgeability of lay actors often remains completely unexplored in orthodox Egyptological approaches. However, in order to be able to study the influence of constraint on behaviour in any particular context of action it is manifestly important to specify relevant aspects of the limits of agents' knowledgeability.

${ }^{123}$ Smith, MDAIK 48 (1992), pp. 218-19; Grajetzki, Burial Customs in Ancient Egypt, 2003. Even though poorer burials often contained fewer and different provisions for the afterlife than the tombs of the elite, this cannot be simply taken as evidence for a lower commitment to funerary beliefs. The humble contents of poorer graves (figurines, amulets, etc.) are more likely to be a reflection of the limited economic means of the deceased as well as the limited self-sufficiency of most people to create certain types of objects such as inscribed stelae and statues.

${ }^{124} \mathrm{~A}$ related issue here is that the ability to employ specialists for the maintenance of the mortuary cult would have depended strongly on the wealth and social background of the deceased. In many cases, this responsibility may simply have fallen to the family or peers of the deceased (ideally the deceased's son), whether literate or not, who carried out such duties according to varying levels of skill, technical knowledge, and commitment. The knowledge and mortuary traditions of such groups may well have been passed down orally, perhaps in particular families, leaving no obvious material residue. The essential point, in any case, is that illiterate individuals too would have been able to bring into play conduct of an apposite kind even if some aspects of the mortuary cult would have been unfamiliar to them; to learn, memorise, and recite the list of standard commodities, consisting of " bread, beer, oxen, birds, alabaster, clothing, and every good and pure thing upon which a god lives "; to bring food offerings to "feed" the deceased, and so forth. Even if their practices would have been distortions or imperfect versions of the practices of the formally-trained specialist, it seems reasonable to postulate that having any mortuary cult would have been preferable to having no mortuary cult at all. By implication one should allow for the possibility, or even probability, of overlap between the categories of "priest" and "family member".

125 The meaning of particular places is not constructed de novo through interaction in each case. Rather, once learned, places have associated expectations and norms that elicit predictable behaviour and proper responses (Rapoport, Meaning of the Built Environment, 1990). In the Saqqara New Kingdom necropolis, the entrance gateways of the larger tombs (which mirrored the monumental gateways of Egyptian temples), the recurrent use of well-known religious symbols, depictions of gods, etc. all provided visual prompts that helped visitors to typify the tomb as a sacred space and place of veneration, which, in turn, informed their experience and allowed them to regularise their behaviour (thus avoiding the flux and indeterminacy that encounters with the completely unfamiliar tend to have). The use of images of gods and the deceased may even have attributed a supernatural agency to the tomb structure, giving visitors the feeling of being watched or perceived, stimulating them to increase self-observation and self-restriction.

${ }^{126}$ It is not easy to determine when the ritual graffiti discussed in this contribution were applied, but it is possible that in some cases this happened only after the tombs in the necropolis had been appropriated for secondary burials. On the whole, these burials are modest and do not belong to the privileged members of the elite. They mostly contain only a few funerary gifts, such as pots with foodstuffs and a small number of amulets, and in most cases the deceased was buried in an undecorated coffin or wrapped in a mat, without any coffin at all. Considering that mortuary cults would have been funded with the resources available, which, in these cases, appear to have been limited, graffiti may have been used as alternative, inexpensive methods to beatify and protect the deceased in the afterlife.

${ }^{127}$ Cf. Haring, From Single Sign to Pseudo-script, 2017.

${ }^{128} \mathrm{~A}$ graffito of three incised triangles in the tomb of Maya and Meryt can perhaps be interpreted as representing the three main pyramids of Giza as suggested by Martin ( Tomb of Maya and Meryt, I, 2012, pl. 62.33). The exterior south face of the enclosure wall of the pyramid of Djoser was once covered with similar pyramid-shaped graffiti (Maarten Raven, personal communication), most of which have now faded or been erased by modern graffiti. Perhaps such graffiti were left in buildings to situate them within a larger sacred landscape.

${ }^{129}$ Navrátilová, The Visitors' Graffiti, 2007; Navrátilová, Visitors' Graffiti, 2015, pp. 258-59. Note, however, that piety was not incompatible with pleasure. Several graffiti address a prayer to the necropolis deities, but state at the same time that the scribe came 'to walk about [the necropolis] for leisure' (Quirke, JEA 72 [1986], p. 88 n. 27).

${ }^{130}$ Cf. Benefiel, AJA 114/1 (2010), pp. 59-101. Textual graffiti in Theban tombs were likewise often careful to respect the official tomb decoration, and in some cases even interact with it. This demonstrates that some graffitists read and reacted to the official tomb decoration (Den Doncker, in Kóthay [ed.], Art and Society 2012, p. 24; Ragazzoli, SAK 42 [2013], pp. 274-75, 284).

${ }^{131}$ Each figure or text has been counted individually. A complete overview is provided in the Appendix. ${ }^{132}$ Tomb N13.1 at Asyut has a markedly different 
distribution. Out of the 201 Pharaonic graffiti identified there, $142(70.7 \%)$ are textual and 59 pictorial (29.3\%).

${ }^{133}$ The textual graffiti from the Memphite necropolis collected by Navrátilová, Visitors' Graffiti, 2015, p. 244, show a different pattern. According to Navrátilová, 95.6\% of the written graffiti in Abusir, Saqqara, and Dahshur were written in hieratic, whereas only two examples (4.4\%), both dating to the Ramesside Period, were written in hieroglyphs. New Kingdom graffiti in tomb N13.1 in Asyut also predominantly used the hieratic script (Verhoeven, in Kahl et al. [eds.], Seven Seasons at Asyut, 2012, p. 49).

${ }^{134}$ Assmann, in Harth and Assmann (eds.), Kultur als Lebenswelt, 1991, pp. 142-44.

135 Dijkstra, Syene, I, 2012.

${ }^{136}$ Defining categories largely depends on the nature of the data. For that reason, there are slight differences between the categories used here and those employed by Dijkstra. Most importantly, the category "furniture" has been added and the category "crosses" removed. In addition, the category "gods and men" has been replaced with "human figures" as the category "gods" requires a confident interpretation of a figure, which is not always possible.

${ }^{137}$ Although the side chapels of most tombs do not have a limestone revetment, people could still have left graffiti on the mud-plastered walls (either by painting or scratching). In the tomb of Antefiqer at Thebes (TT60) it has been observed that the entrance doorway contained mostly figural graffiti whereas the interior spaces bore mostly textual graffiti. Moreover, the graffiti in the entrance were more crudely executed. Such a distribution of graffiti has not been observed in the Saqqara tombs studied in this article.

${ }^{138}$ Cf. Benefiel, AJA 114/1 (2010), pp. 59-101.

${ }^{139}$ Chauvet, in Bárta et al. (eds.), Abusir and Saqqara, 2011, p. 271; Harrington, Living with the Dead, 2012, p. 94.

${ }^{140}$ Assmann, in Strudwick and Taylor (eds.), The Theban Necropolis, 2003, p. 51; Hays, in Wendrich (ed.), UCLA Encyclopedia of Egyptology, 2010, pp. 8-9.

${ }^{141}$ However, note that many graffiti hardly aimed at attracting an observer's attention, as noted above.

${ }_{142}$ Černý and Gunn, in Firth and Quibell (eds.), The Step Pyramid, I, 1935, p. 78; Helck, ZDMG 102 (1952), pp. 39-46; Navrátilová, The Visitors' Graffiti, 2007, pp. 100-01; Navrátilová, Visitors' Graffiti, 2015, pp. 156-61.

${ }^{143}$ Navrátilová, in Bareš et al. (eds.), Egypt in Transition, 2010, p. 310. Textual responses to other graffiti are often straightforward to recognise and relatively easy to follow. In contrast it is far more difficult to unambiguously identify “dialogues” between pictorial graffiti. In the latter case, the clustering of similar motifs made by different graffitists may be a useful criterion (e.g. the jackal graffiti in the tomb of Ptahemwia).

${ }^{144}$ These figures do not include the names and titles that devotionally "tag" figures in the official tomb decoration.

${ }^{145}$ Navrátilová, in Bareš et al. (eds.), Egypt in Transition,
2010, p. 329.

${ }^{146}$ While allowing, of course, for various degrees of access to technical knowledge.

${ }^{147}$ Cf. Assmann, Death and Salvation, 2005, pp. 41-56.

\section{Bibliography}

Abitz, F., Statuetten in Schreinen als Grabbeigaben in den ägyptischen Königsgräbern der 18. und 19. Dynastie

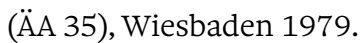

Allen, T.G., The Book of the Dead or Going Forth by Day: Ideas of the Ancient Egyptians Concerning the Hereafter as Expressed in Their Own Terms (SAOC 37), Chicago 1974.

Altenmüller, H., "Abydosfahrt”, in: W. Helck and W. Westendorf (eds.), Lexikon der Ägyptologie 1, Wiesbaden 1975, pp. 42-47.

Altenmüller, H., Die Apotropaia und die Götter Mittelägyptens: eine typologische Untersuchung der sog. „Zaubermesser“ des Mittleren Reichs, München 1965.

Altenmüller, H., Die Wanddarstellungen im Grab des Mehu in Saqqara (AV 42), Mainz am Rhein 1998.

Andrews, C., Amulets of Ancient Egypt, London 1994.

Arnold, D., Building in Egypt: Pharaonic Stone Masonry, New York/Oxford 1991.

Assmann, J., Das Grab des Amenemope TT 41 (Theben 3), Mainz 1991.

Assmann, J., Death and Salvation in Ancient Egypt, Ithaca 2005.

Assmann, J., “Gebrauch und Gedächtnis: Die zwei Kulturen des pharaonischen Ägypten”, in: D. Harth and A. Assmann (eds.), Kultur als Lebenswelt und Monument, Frankfurt 1991, pp. 135-52.

Assmann, J., "The Ramesside Tomb and the Construction of Sacred Space", in: N. Strudwick and J.H. Taylor (eds.), The Theban Necropolis: Past, Present, Future, London 2003, pp. 46-52.

Baines, J. and C. Eyre, "Four Notes on Literacy”, in: J. Baines (ed.), Visual and Written Culture in Ancient Egypt, Oxford 2007, pp. 63-94.

Baines, J., "Literacy and Ancient Egyptian Society”, MAN 18 (1983), pp. 572-99.

Baines, J., "The Destruction of the Pyramid Temple of Sahure", GM 4 (1973), pp. 9-14.

Baird, J.A., and C. Taylor, "Ancient Graffiti in Context: Introduction", in: J.A. Baird and C. Taylor (eds.), Ancient Graffiti in Context, London 2011, pp. 1-19.

Banksy, R., Banging Your Head Against a Brick Wall, London 2001.

Bareš, L., "The Destruction of the Monuments at the Necropolis of Abusir”, in: M. Bartá and J. Krejcí (eds.), Abusir and Saqqara in the Year 2000 (Archív orientální Supplementa 9), Prague 2000, pp. 1-16.

Barta, W., Aufbau und Bedeutung der altägyptischen Opferformel (̈̈F 24), Glückstadt 1968.

Benefiel, R., "Dialogues of Ancient Graffiti in the House of Maius Castricius at Pompeii”, AJA 114/1 (2010), pp. 59-101.

Boeser, P.A.A., Beschrijving van de Egyptische verzameling in het Rijksmuseum van Oudheden te Leiden, IV: De monumenten van het Nieuwe Rijk, eerste afdeeling: Graven, 's-Gravenhage 1911.

Borchardt, L., Das Grabdenkmal des Königs Sa'hu-Re', I: Der Bau, Leipzig 1910. 
Bormann, L., "Felsinschriften und Feldbilder der Region von Assuan: Ein neuer epigraphischer Befund auf der Insel Sehel”, Archäologie in Ägypten: Magazin des Deutschen Archäologischen Instituts Kairo 4 (2016), pp. 32-33.

Bourriau, J., Pharaohs and Mortals: Egyptian Art in the Middle Kingdom, Cambridge 1988.

Bowlby, J., Attachment and Loss, I: Attachment, New York 1969.

Bowlby, J., Attachment and Loss, III: Loss: Sadness and Depression, New York 1980.

Brown, D.E., Human Universals, New York 1991.

Castiglione, L., "Vestigia”, AAASH 22 (1970), pp. 95-122.

Chauvet, V., "Entrance-Porticoes and Portico-Chapels: The Creation of an Outside Ritual Stage in Private Tombs of the Old Kingdom”, in: M. Bárta, F. Coppens, and J. Krejcí (eds.), Abusir and Saqqara in the Year 2010, I, Prague 2010, pp. 261-311.

Cooper, J., The Medieval Nile: Route, Navigation, and Landscape in Islamic Egypt, Cairo 2014.

Cruz-Uribe, E., “Graffiti (Figural)”, in: W. Wendrich (ed.), UCLA Encyclopedia of Egyptology, Los Angeles 2008. http://escholarship.org/uc/item/7v92z43m.

Cruz-Uribe, E., Hibis Temple Project Volume 3: The Graffiti from the Temple Precinct, San Antonio 2008.

Darnell, J.C., "Graffiti and Rock Inscriptions”, in: J. Allen and I. Shaw (eds.), Oxford Handbook of Egyptology, Oxford, in press.

Darnell, J.C., Theban Desert Road Survey, II: The Rock Shrine of Pahu, Gebel Akhenaton, and Other Rock Inscriptions from the Western Hinterland of Qamûla (YEP 1), New Haven 2013.

Darnell, J.C., Theban Desert Road Survey in the Egyptian Western Desert, I: Gebel Tjauti Rock Inscriptions 1-45 and Wadi el-Ḥ̂l Rock Inscriptions 1-45, Chicago 2002.

Davies, N. de Garis, The Tomb of Antefoker, Vizier of Sesostris I, and of His Wife, Senet (No. 60) (TTS 2), London 1920.

Davies, W.V., L. Prada and S. Woodhouse, "Monuments of Elkab: Taking a Closer Look”, EgArch 53 (2018), pp. 4-12.

Demarée, R., "A Hieratic Graffito in the Tomb of Ptahemwia”, Saqqara Newsletter 7 (2009), pp. 11-12.

Den Doncker, A., "Theban Tomb Graffiti During the New Kingdom: Research on the Reception of Ancient Egyptian Images by Ancient Egyptians", in: K.A. Kóthay (ed.), Art and Society: Ancient and Modern Contexts of Egyptian Art: Proceedings of the International Conference Held at the Museum of Fine Arts, Budapest, 13-15 May 2010, Budapest 2012, pp. 23-34.

Der Manuelian, P., "Semi-Literacy in Egypt: Some Erasures from the Amarna Period”, in: E. Teeter and J.A. Larson (eds.), Gold of Praise: Studies on Ancient Egypt in Honor of Edward F. Wente, Chicago 1999, pp. 285-98.

Desclaux, V., "La syntaxe des appels aux vivants”, BIFAO 117 (2017), pp. 161-202.

Desclaux, V., "Les appels aux passants en Égypte ancienne. Approche historique d'un genre littéraire" (doctoral dissertation, université Lumière-Lyon 2), Lyon 2014.

De Vries, D.J., Met het oog op het Laatste Oordeel: De geboorte van het individu in de westerse kunst, Utrecht 2014.
De Wit, C., Le rôle et le sens du lion dans l'Égypte ancienne, Leiden 1951.

Di Cerbo, C., and R. Jasnow, "Recent Documentation of Medinet Habu Graffiti by the Epigraphic Survey", in: P.F. Dorman and B.M. Bryan (eds.), Perspectives on Ptolemaic Thebes: Papers from the Theban Workshop 2006 (SAOC 65), Chicago 2011, pp. 35-51.

Dijkstra, J.H.F., Syene, I: The Figural and Textual Graffiti from the Temple of Isis at Aswan (B̈̈BA 18), Mainz 2012.

Dodson, A., and S. Ikram, The Tomb in Ancient Egypt: Royal and Private Sepulchres from the Early Dynastic Period to the Romans, London 2008.

Dorn, A., "Von Graffiti und Königsgräbern des Neuen Reiches”, in: B.J.J. Haring, O.E. Kaper and R. Van Walsem (eds.), The Workman's Progress: Studies in the Village of Deir el-Medina and Other Documents from Western Thebes in Honour of Rob Demarée (EU 28), Leiden and Leuven 2014, pp. 57-91.

Dunham, D., "Four New Kingdom Monuments in the Museum of Fine Arts, Boston”, JEA 21/2 (1935), pp. 147-51.

DuQuesne, T., Anubis, Upwawet, and Other Deities: Personal Worship and Official Religion in Ancient Egypt. Previously Unseen Treasures from the Salakhana Trove, Asyut, with Collateral Objects from the Galleries of the Egyptian Museum, Cairo, and Elsewhere, Cairo 2007.

El-Aguizy, O., "A Preliminary Report on Three Seasons of Excavations at Saqqara: 2005-2007", Bulletin of the Egyptian Museum 4 (2007), pp. 41-50.

Esquieu, Y., "Sur les traces des tailleurs de pierre au Moyen Age : pour une lecture attentive des marques de tâcherons", in : C. De la Roncière (ed.), Histoire et société. Mélanges offerts à Georges Duby, IV, Aix-enProvence 1992, pp. 114-29.

Étienne, M., Journey to the Afterlife: Egyptian Antiquities from the Louvre, Sydney 2006.

Evans, L., "The Shedshed of Wepwawet: An Artistic and Behavioural Interpretation", JEA 97 (2011), pp. 103-15.

Fábián, Z.I., “Graffiti in TT 32”, in: E. Luft (ed.), The Intellectual Heritage of Egypt. Studies Presented to László Kákosy by Friends and Colleagues on the Occasion of His 60 $0^{\text {th }}$ Birthday, Budapest 1992, pp. 137-56.

Faulkner, R.O., The Ancient Egyptian Book of the Dead, London 1985.

Firth, C.M. and B. Gunn, Teti Pyramid Cemeteries, I-II (Excavations at Saqqara), Cairo 1926.

Firth, C.M. and J.E. Quibell, The Step Pyramid, I (Excavations at Saqqara), Cairo 1935.

Fischer-Elfert, H.-W., "Representations of the Past in New Kingdom Literature”, in: J. Tait (ed.), 'Never Had the Like Occurred': Egypt's View of Its Past, London 2003, pp. 119-37.

Fleming, J., Graffiti and the Writing Arts of Early Modern England, London 2001.

Frood, E., Biographical Texts from Ramessid Egypt (Writings from the Ancient World 26), Leiden and Boston 2007.

Frood, E., "Egyptian Temple Graffiti and the Gods: Appropriation and Ritualization in Karnak and Luxor", in: D. Ragavan (ed.), Heaven on Earth: Temples, Ritual, and Cosmic Symbolism in the Ancient World, Chicago 2013, pp. 285-318.

Fuchs, S., Warum steht Herrmann kopf? Steinmetzzeichen 
in Maulbronn als Quelle zur Rekonstruktion der Werkstattorganisation, Heidelberg 2009. DOI: http://archiv. ub.uni-heidelberg.de/volltextserver/11648/.

Gardiner, A.H., T.E. Peet and J. Černý, The Inscriptions of Sinai I: Introduction and Plates (MEES 36), London 1952.

Gardiner, A.H. and K. Sethe, Egyptian Letters to the Dead, London 1928.

Gohary, S., "A Monument of the Royal Scribe Tjuroy", BIFAO 91 (1991), pp. 191-94.

Gohary, S., "The Tomb-Chapel of the Royal Scribe Amenemone at Saqqara”, BIFAO 91 (1991), pp. 195-205.

Gohary, S., The Twin Tomb Chapel of Nebnefer \& His Son Mahu at Sakkara, Cairo 2009.

Goneim, Z., Horus Sekhem-khet: The Unfinished Step Pyramid at Saqqara, I (Excavations at Saqqara), Cairo 1957.

Goulding, E., What Did the Poor Take with Them? An Investigation into Ancient Egyptian Eighteenth and Nineteenth Dynasty Grave Assemblages of the Non-Elite from Qau, Badari, Matmar and Gurob, London 2013.

Graefe, E., "Upuaut", in: W. Helck and W. Westendorf (eds.), Lexikon der Ägyptologie, VI, Wiesbaden 1986, pp. 862-64.

Grajetzki, W., Burial Customs in Ancient Egypt: Life in Death for Rich and Poor, London 2003.

Haring, B., From Single Sign to Pseudo-Script: An Ancient Egyptian System of Workmen's Identity Marks (Culture \& History of th Ancient Near East 93), Leiden and Boston 2017.

Harrington, N., Living with the Dead: Ancestor Worship and Mortuary Ritual in Ancient Egypt, Oxford 2012.

Hartley, M., A. Buck and S. Binder, "Canine Interments in the Teti Cemetery North at Saqqara During the Graeco-Roman Period”, in: M. Bárta, F. Coppens, and J. Krejcí (eds.), Abusir and Saqqara in the Year 2010, I, Prague 2011, pp. 17-29.

Hays, H.M., “Funerary Rituals (Pharaonic Period)”, in: J. Dieleman and W. Wendrich (ed.), UCLA Encyclopedia of Egyptology, Los Angeles 2010. https://escholarship. org/uc/item/1r32g9zn.

Helck, W., "Die Bedeutung der ägyptischen Besucherinschriften”, ZDMG 102 (1952), pp. 39-46.

Helck, W., “Die Besucherinschriften”, in: E. Edel, Das Sonnenheiligtum des Königs Userkaf, II: die Funde (BÄBA 8), Wiesbaden 1969, pp. 115-21.

Iskander, S. and O. Goelet, The Temple of Rameses II in Abydos, Volume 1: Wall Scenes, Atlanta 2015.

Jacquet-Gordon, H., The Temple of Khonsu, III: The Graffiti on the Khonsu Temple Roof at Karnak. A Manifestation of Personal Piety (OIP 123), Chicago 2003.

Jaritz, H., "Der Totentempel des Merenptah in Qurna: I. Grabungsbericht (1.-6. Kampagne),", MDAIK 48 (1992), pp. 65-91.

Jeffreys, D. and H.S. Smith, The Anubieion at Saqqâra, I: The Settlement and the Temple Precinct (EES ExcMem 54), London 1988.

Kahl, J., “Ein Zeugnis altägyptischer Schulausflüge”, $G M$ 211 (2006), pp. 25-29.

Kanawati, N., A. El-Khouli, A. McFarlane, and N.V. Maksoud, Excavations at Saqqara North-West of Teti's Pyramid, I, Sydney 1984.

Kanawati, N. and A. El-Khouli, Excavations at Saqqara North-West of Teti's Pyramid, II, Sydney 1984.
Kanawati, N. and M. Abder-Raziq, The Teti Cemetery at Saqqara, V: The Tomb of Hesi, Warminster 1999.

Keegan, P., "Blogging Rome: Graffiti as Speech-Act and Cultural Discourse”, in: J.A. Baird and C. Taylor (eds.), Ancient Graffiti in Context, New York 2011, pp. 165-90.

Keegan, P., Graffiti in Antiquity, Abingdon 2014.

Khaled, M.I., "A Visitor at the Causeway of Sahura at Abusir”, in: M. Bárta, F. Coppens, and J. Krejcí (eds.), Abusir and Saqqara in the Year 2010, Prague 2011, pp. 512-17.

Kozloff, A.P., B.M. Bryan, and L.M. Berman, Egypt's Dazzling Sun: Amenhotep III and His World, Cleveland 1992.

Kuhlmann, K.P., “Eine Beschreibung der Grabdekoration mit der Aufforderung zu kopieren und zum Hinterlassen von Besucherinschriften aus saitischer Zeit”, MDAIK 29/2 (1973), pp. 207-13.

Lacau, P., Stèles du Nouvel Empire (CGC Nos 3400134064, 34065-34189), Cairo 1909-16.

Málek, J., "A Meeting of the Old and the New: Saqqâra During the New Kingdom”, in: A.B. Lloyd (ed.), Studies in Pharaonic Religion and Society in Honour of J. Gwyn Griffiths, London 1992, pp. 57-76.

Manniche, L., City of the Dead: The Tombs of the Nobles at Luxor, Cairo 1987.

Martin, G.T., Corpus of Reliefs of the New Kingdom from the Memphite Necropolis and Lower Egypt, London 1987.

Martin, G.T., The Memphite Tomb of Horemheb, Commander-in-Chief of Tut'ankhamun, I: The Reliefs, Inscriptions, and Commentary (EES ExcMem 55), London 1989.

Martin, G.T., The Tomb-Chapels of Paser and Ra'ia at Saqqâra (EES EM 52), London 1985.

Martin, G.T., The Tomb of Maya and Meryt, I: The Reliefs, Inscriptions, and Commentary (EES ExcMem 99), London 2012.

Martin, G.T., The Tomb of Tia and Tia: A Royal Monument of the Ramesside Period in the Memphite Necropolis (EES ExcMem 58), London 1997.

Martin, G.T., The Tombs of Three Memphite Officials: Ramose, Khay and Pabes (EES ExcMem 66), London 2001.

Meskell, L., Archaeologies of Social Life: Age, Sex, Class et Cetera in Ancient Egypt, Oxford 1999.

Meskell, L., Object Worlds in Ancient Egypt: Material Biographies Past and Present, Oxford and New York 2004.

Meskell, L., Private Life in New Kingdom Egypt, Princeton 2002.

Morenz, L.D., "Literature as a Construction of the Past in the Middle Kingdom”, in: J. Tait (ed.), 'Never Had the Like Occurred': Egypt's View of Its Past, London 2003, pp. 101-13.

Muir, E., Ritual in Early Modern Europe, Cambridge 1997.

Müller, C., "Anruf an Lebende", in: W. Helck and E. Otto (eds.), Lexikon der Ägyptologie, I, Wiesbaden 1975, pp. 293-99.

Munro, P., "Einige Votivstellen an Wp wzwt", ZÄS 88 (1962), pp. 48-58.

Munro, P., "Some Ramesside Monuments from the Area of Ny-Neter in the Ounas Cemetery, Saqqara”, in: A.-P. Zivie (ed.), Memphis et ses nécropoles au Nouvel Empire, nouvelles données, nouvelles questions: actes $d u$ colloque CRNS, Paris, 9 au 11 octobre 1986, Paris 1988, pp. 73-79. 
Navrátilová, H., “Graffiti Spaces”, in: L. Bareš, F. Coppens, and K. Smoláriková (eds.), Egypt in Transition: Social and Religious Development of Egypt in the First Millennium BCE, Prague 2010, pp. 305-32.

Navrátilová, H., The Visitors' Graffiti of Dynasties XVIII and XIX in Abusir and Northern Saqqara, Prague 2007.

Navrátilová, H., Visitors' Graffiti of Dynasties 18 and 19 in Abusir and Northern Saqqara: With a Survey of the Graffiti at Giza, Southern Saqqara, Dahshur and Maidum, Wallasey 2015.

Ockinga, B.G., Amenemone the Chief Goldsmith: A New Kingdom Tomb in the Teti Cemetery at Saqqara (ACE Reports 22), Oxford 2004.

Ockinga, B.G., "Evidence for the New Kingdom Tomb Structures in the Teti Pyramid Cemetery North: Insights from the Macquarie Excavations", in: L. Evans (ed.), Ancient Memphis 'Enduring is the Perfection'. Proceedings of the International Conference Held at Macquarie University, Sydney on August 14-15, 2008 (OLA 214), Leuven 2012, pp. 371-95.

Ockinga, B.G., "In Search of the New Kingdom Tombs in the Teti Pyramid Cemetery North: Preliminary Results of the 2009 and 2010 Seasons Conducted by Macquarie University", in: M. Bárta, F. Coppens, and J. Krejcí (eds.), Abusir and Saqqara in the Year 2010, Prague 2011, pp. 119-38.

Ockinga, B.G., "Use, Reuse, and Abuse of 'Sacred Space': Observations from Dra Abu al-Naga”, in: P.F. Dorman and B.M. Bryan (eds.), Sacred Space and Sacred Function in Ancient Thebes, Chicago 2007, pp. 139-62.

Osing, J., Das Grab des Nefersecheru in Zawyet Sultan, Berlin 1992.

Pasquali, S. and B. Gessler-Löhr, "Un nouveau relief du grand intendant de Memphis, Ipy, et le temple de Ptah du terrain-b’h", BIFAO 111 (2011), pp. 281-99.

Peden, A.J., The Graffiti of Pharaonic Egypt: Scope and Roles of Informal Writings (c. 3100-332 B.C.) (PdÄ 17), Leiden 2001.

Pinch, G., Magic in Ancient Egypt, London 1994.

Pinker, S., The Blank Slate: The Modern Denial of Human Nature, London 2002.

Plesch, V.B., "Memory on the Wall: Graffiti on Religious Wall Paintings", JMEMS 32/1 (2002), pp. 167-98.

Pusch, E.B., "Senet”, in: W. Helck and W. Westendorf (eds.), Lexikon der Ägyptologie 5, Wiesbaden 1984, pp. 852-55.

Quibell, J.E. and A.G.K. Hayter, Excavations at Saqqara, Teti Pyramid, North Side (Excavations at Saqqara), Cairo 1927.

Quirke, S., Egyptian Literature 1800 BC: Questions and Readings (GHP Egyptology 2), London 2004.

Quirke, S., "The Hieratic Texts in the Tomb of Nakht the Gardener, at Thebes (No. 161) as Copied by Robert Hay", JEA 72 (1986), pp. 79-90.

Quirke, S. and J. Spencer, The British Museum Book of Ancient Egypt, London 1992.

Ragazzoli, C., “Genres textuels et supports matériels : une inscription de visiteur comme exercice sur ostracon (Ostracon University College 31918)", NeHeT 4 (2016), pp. 65-76.

Ragazzoli, C., La grotte des scribes à Deir el-Bahari : la tombe MMA 504 et ses graffiti (MIFAO 135), Cairo 2017.
Ragazzoli, C., “The Social Creation of a Scribal Place: The Visitors' Inscriptions in the Tomb Attributed to Antefiqer (TT 60) (With Newly Recorded Graffiti)", SAK 42 (2013), pp. 269-325.

Ragazzoli, C., Ö. Harmanşah and C. Salvador, "Introduction”, in: C. Ragazzoli, Ö. Harmanşah, C. Salvador, and E. Frood (eds.), Scribbling Through History. Graffiti, Places and People from Antiquity to Modernity, London 2018, pp. 1-15.

Ragazzoli, C., Ö. Harmanşah, C. Salvador, and E. Frood (eds.), Scribbling Through History. Graffiti, Places and People from Antiquity to Modernity, London 2018.

Rapoport, A., The Meaning of the Built Environment: A Nonverbal Communication Approach, Tucson 1990.

Raven, M.J., "The 30th Dynasty Nespamedu Family", OMRO 61 (1980), pp. 19-31.

Raven, M.J., “The Temple of Taffeh, II: The Graffiti”, OMRO 79 (1999), pp. 81-102.

Raven, M.J., The Tomb of Iurudef: A Memphite Official in the Reign of Ramesses II (EES ExcMem 57), London 1991.

Raven, M.J., The Tomb of Maya and Meryt, II: Objects and Skeletal Remains (EES ExcMem 65), Leiden and London 2001.

Raven, M.J., The Tomb of Pay and Raia at Saqqara (EES ExcMem 74), Leiden and London 2005.

Raven, M.J. and R. van Walsem, The Tomb of Meryneith at Saqqara (PALMA-Eg 10), Turnhout 2014.

Raven, M.J., R. van Walsem, B.G. Aston, L. Horácková and N. Warner, "Preliminary Report on the Leiden Excavations at Saqqara, Season 2006-7: The Tomb of Ptahemwia”, JEOL 40 (2006-2007), pp. 9-39.

Raven, M.J., V. Verschoor, M. Vugts, and R. van Walsem, The Memphite Tomb of Horemheb, Commander-in-chief of Tutankhamun, V: The Forecourt and the Area South of the Tomb, with Some Notes on the Tomb of Tia (PALMA 6), Turnhout 2011.

Ritner, R.K., "Magic: An Overview”, in: D.B. Redford (ed.), The Oxford Encyclopedia of Ancient Egypt, II, Oxford 2001, pp. 321-26.

Salvador, C., "From the Realm of the Dead to the House of the God: The New Kingdom Appeals to the Living in Context at Thebes”, in: K. Accetta, R. Fellinger, S. Musselwhite, P. Lourenço Conçalves, and W.P. van Pelt (eds.), Current Research in Egyptology 2013: Proceedings of the Fourteenth Annual Symposium: University of Cambridge, United Kingdom March 19-22, 2013, Oxford 2014, pp. 153-67.

Salvador, C., "Graffiti and Sacred Space: New Kingdom Expressions of Individuality in the Court of the Seventh Pylon at Karnak", in: M. Ullmann (ed.), 10. Ägyptologische Tempeltagung: ägyptische Tempel zwischen Normierung und Individualität. München, 29.-31. August 2014, Wiesbaden 2016, pp. 111-28.

Schneider, H.D., The Memphite Tomb of Horemheb, Commander-in-Chief of Tut'ankhamun, II: A Catalogue of the Finds (EES ExcMem 60), Leiden and London 1996.

Smith, S.T., "Intact Tombs of the Seventeenth and Eighteenth Dynasties from Thebes and the New Kingdom Burial System", MDAIK 48 (1992), pp. 193-31.

Sowada, K., T. Callaghan and P. Bentley, The Teti Cemetery at Saqqara, IV: Minor Burials and Other Material (ACE Reports 12), Warminster 1999. 
Stadler, M.A., Weiser und Wesir: Studien zu Vorkommen, Rolle und Wesen des Gottes Thot im ägyptischen Totenbuch (Orientalische Religionen in der Antike 1), Tübingen 2009.

Staring, N., "Graffiti on a Thirteenth Dynasty Stela from Abydos (Louvre C8)", in: C. Di Biase-Dyson and L. Donovan (eds.), The Cultural Manifestation of Religious Experience. Studies in Honour of Boyo G. Ockinga, Münster 2017, pp. 251-62.

Staring, N., "Interpreting Figural Graffiti: Case Studies from a Funerary Context", in: M. Horn, J. Kramer, D. Soliman, N. Staring, C. Van den Hoven, and L. Weiss (eds.), Current Research in Egyptology XI. Proceedings of the Eleventh Annual Symposium Which Took Place at Leiden University, January 2010, Oxford 2011, pp. $145-56$.

Staring, N., "Products of the Physical Engagement with Sacred Space: The New Kingdom Non-Textual Tomb-graffiti at Saqqara”, in: B.J.J. Haring, K.V.J. van der Moezel, and D.M. Soliman (eds.), Decoding Signs of Identity. Egyptian Workmen's Marks in Archaeological, Historical, Comparative and Theoretical Perspective. Proceedings of a Conference in Leiden, 13-15 December 2013 (EU 32), Leiden and Leuven 2018, pp. 79-112.

Sternberg, H., "Sakhmet”, in: W. Helck and W. Westendorf (eds.), Lexikon der Ägyptologie, V, Wiesbaden 1984, pp. 323-33.

Stevens, A., Private Religion at Amarna. The Material Evidence (BAR-IS 1587), Oxford 2006.

Taylor, J.H., Death and the Afterlife in Ancient Egypt (Hathor 5), London 2001.

Tawfik, S., "Recently Excavated Ramesside Tombs at Saqqara, 1: Architecture”, MDAIK 47 (1991), pp. 403-9.

The Epigraphic Survey, The Tomb of Kheruef, Theban Tomb 192 (OIP 102), Chicago 1980.

Turner, G., "Bahamian Ship Graffiti”, IJNA 35/2 (2006), pp. 253-73.

Van Pelt, W.P. and N. Staring, “The Graffiti”, in: M.J. Raven et al., The Tombs of Ptahemwia and Sethnakht at Saqqara (PALMA-Eg 22), Leiden, in press.

Verhoeven, U., "Literatur im Grab - Der Sonderfall Assiut”, in: G. Moers, K. Widmaier, A. Giewekemeyer, A. Lümers, and R. Ernst (eds.), Dating Egyptian Literary
Texts (LingAeg SM 11), Hamburg 2013, pp. 139-58. Verhoeven, U., “The New Kingdom Graffiti in Tomb N13.1: An Overview”, in: J. Kahl, M. el-Khadragy, U. Verhoeven, and A. Kilian (eds.), Seven Seasons at Asyut. First Results of the Egyptian-German Cooperation in Archaeological Fieldwork: Proceedings of an International Conference at the University of Sohag, 10th-11th of October, 2009, Wiesbaden 2012, pp. 47-58.

Wachsmann, S., Seagoing Ships and Seamanship in the Bronze Age Levant, London 1998.

Waitkus, W., “Zur Deutung einiger apotropäischer Götter in den Gräbern im Tal der Königinnen und im Grabe Ramses III”, GM 99 (1987), pp. 51-82.

Waseda University, Institute of Egyptology, Abusir South [II], Tokyo 2006 (in Japanese).

Weiss, L., Religious Practice at Deir el-Medina (EU 29), Leiden and Leuven 2015.

Wente, E., Letters from Ancient Egypt (Writings from the Ancient World 1), Atlanta 1990.

Wiese, A. and A. Brodbeck (eds.), Tutankhamun, the Golden Beyond: Tomb Treasures from the Valley of the Kings, Basel 2004.

Wildung, D., “Das Nachleben des Sahure”, in: V. Brinkmann (ed.), Tod und Leben eines großen Pharao. Eine Ausstellung der Liebieghaus Skulpturensammlung, Frankfurt am Main, 24. Juni bis 28. November 2010, Frankfurt and München 2010, pp. 275-77.

Wise, E., "An 'Odor of Sanctity': The Iconography, Magic, and Ritual of Egyptian Incense", Studia Antiqua 7/1 (2009), pp. 67-80.

Zivie, A.-P., “'Aper-el et ses voisins: considérations sur les tombes rupestres de la XVIIIe dynastie à Saqqarah”, in: A.-P. Zivie (ed.), Memphis et ses nécropoles au Nouvel Empire. Nouvelles données, nouvelles questions : actes $d u$ colloque CRNS, Paris, 9 au 11 octobre 1986, Paris 1988, pp. 103-12.

Zivie, A.-P., La tombe de Maïa: mère nourricière du roi Toutânkhamon et grande du harem (Bub.I.20) (Les tombes du Bubasteion à Saqqara 1), Toulouse 2009.

Zivie, A.-P., La tombe de Thoutmes, directeur des peintres dans la Place de Maât (Bub.I.19) (Les tombes du Bubasteion à Saqqara 2), Toulouse 2013. 


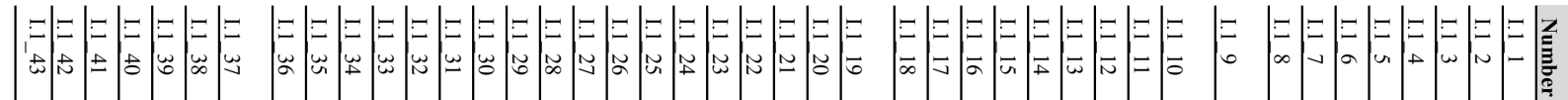

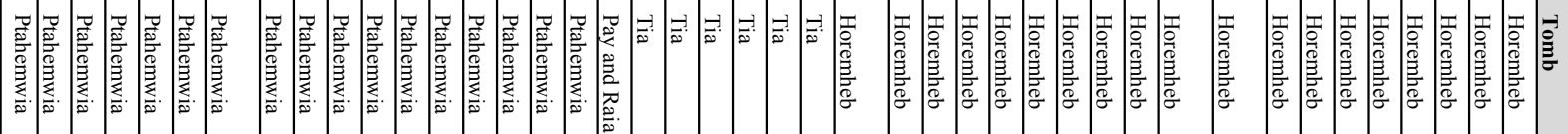

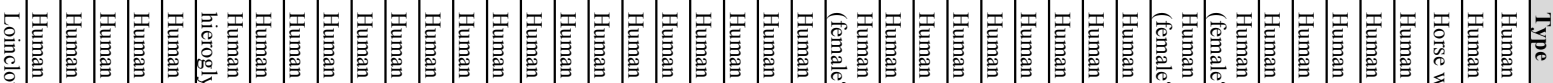

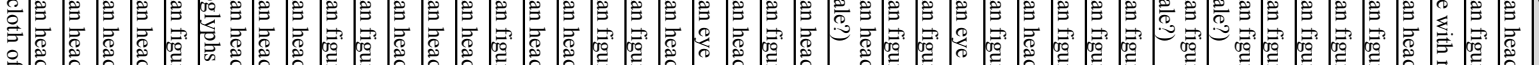

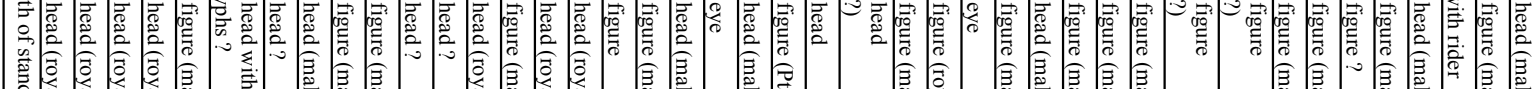

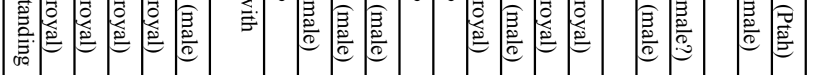
旁虔

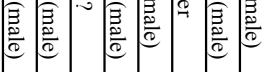

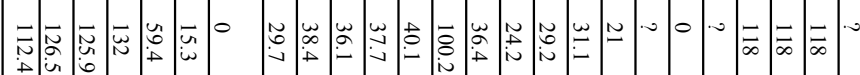

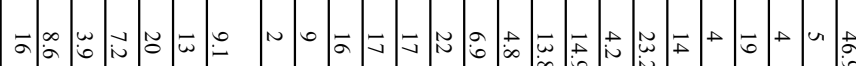

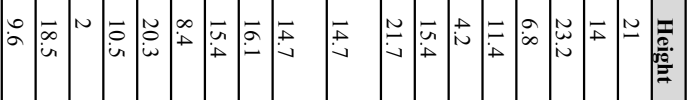

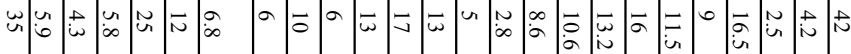

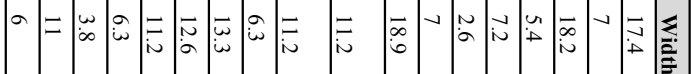

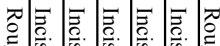

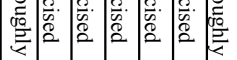
管

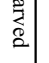

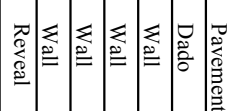
望

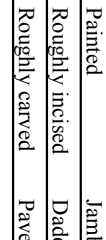
. $\overrightarrow{0 .}$

\section{ت.} (1)

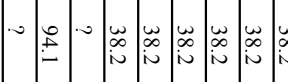

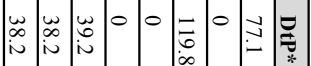

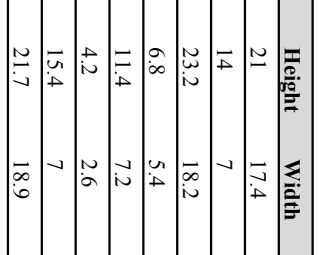

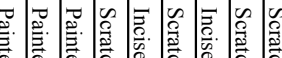

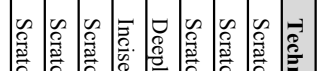

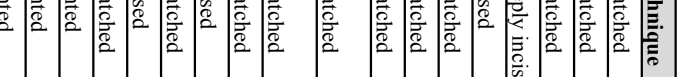
竞:

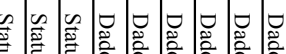 )}

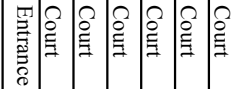
事

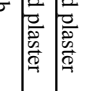

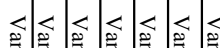

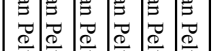

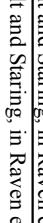

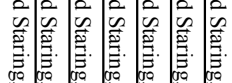

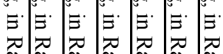

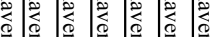

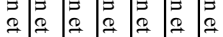

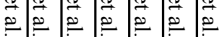

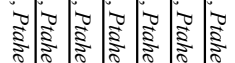

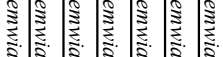

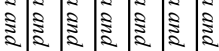

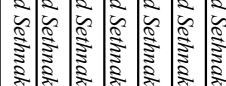

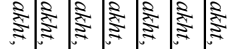
E: E: E: E:

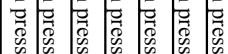

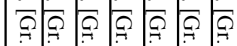

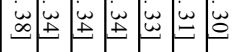

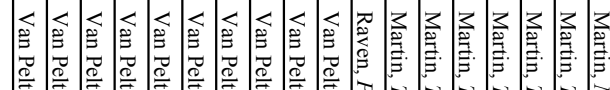

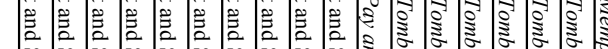

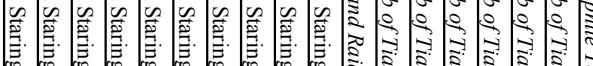

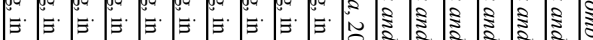

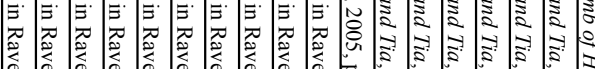

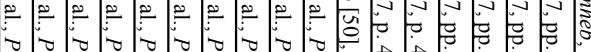

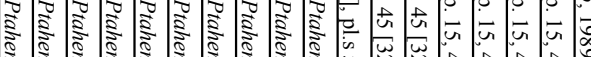

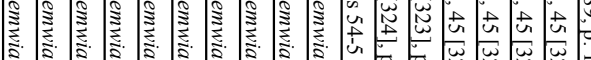

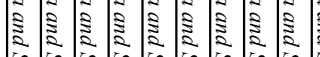

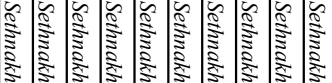
.......

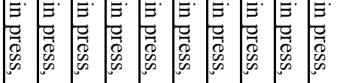

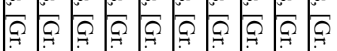

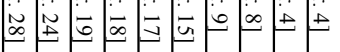

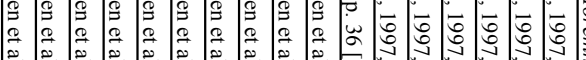

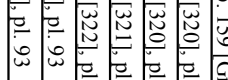

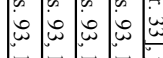

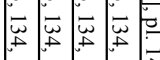

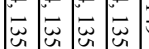

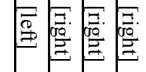

套

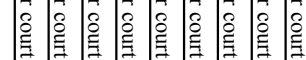

$3 \sqrt[3]{3} 3 \sqrt{3} 3 \sqrt{3}$ . . E.

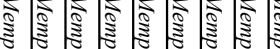

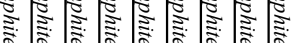

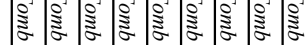

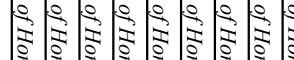

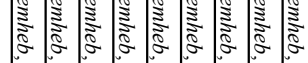

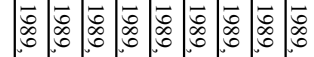

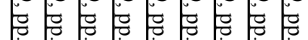

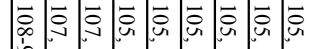

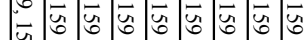

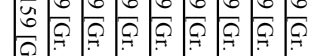

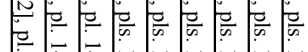

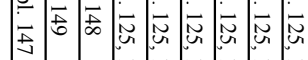

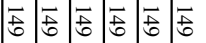

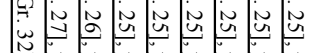

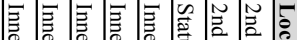
(1)

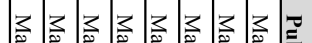
E E

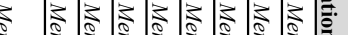
总

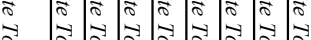

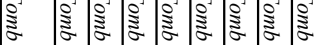

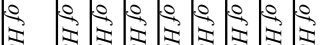
$\frac{1}{2}$

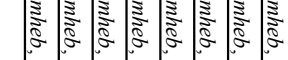

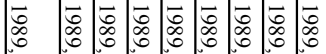
E $=0 \div=0$

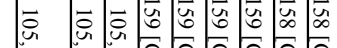

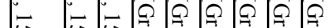

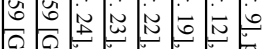
$\because ?$

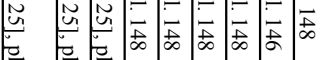

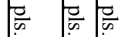
v F

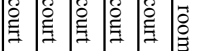




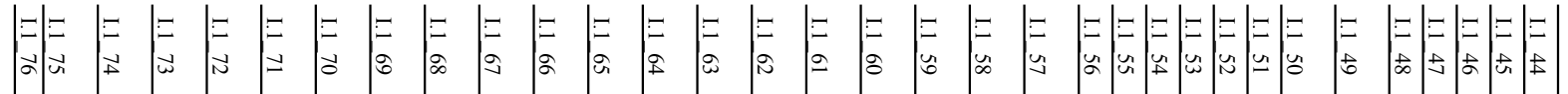

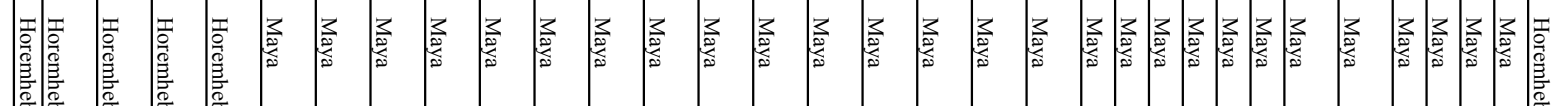

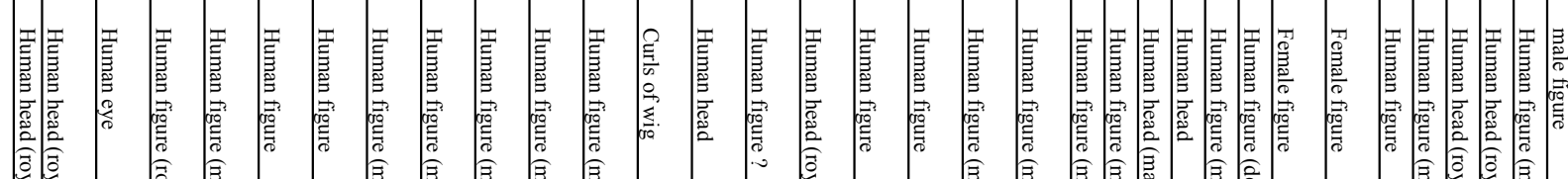

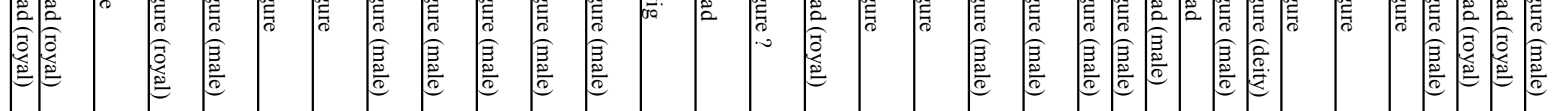

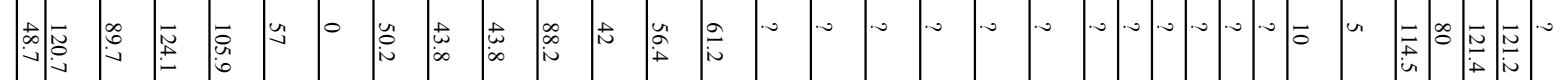

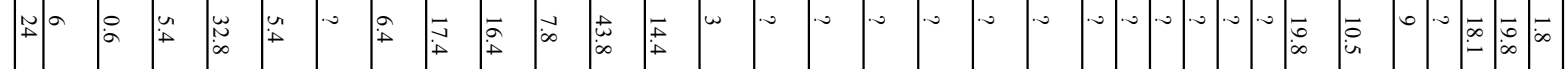

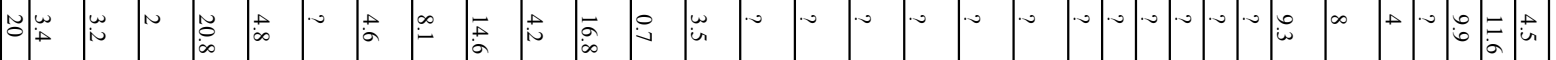

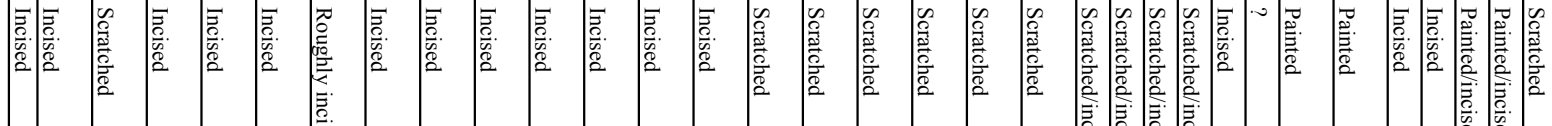
药

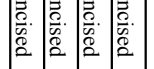

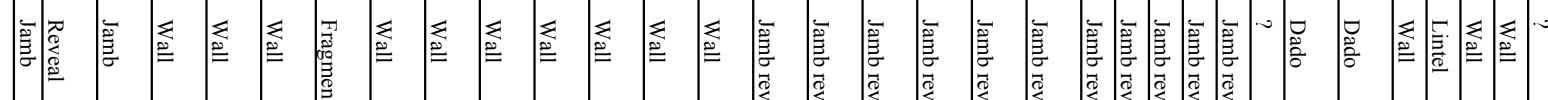

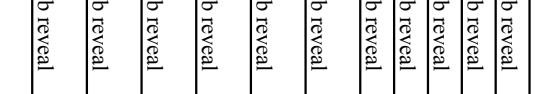

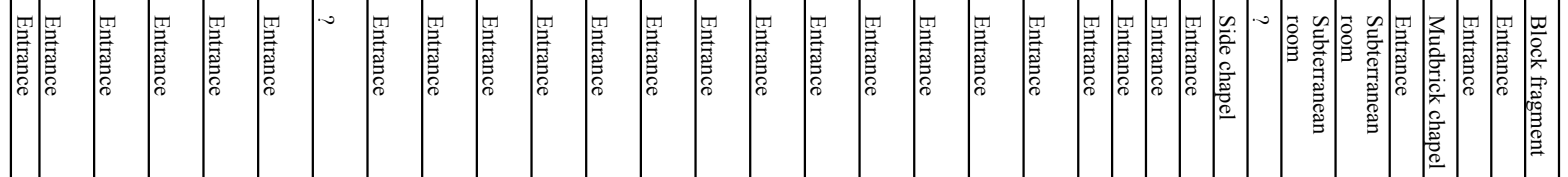

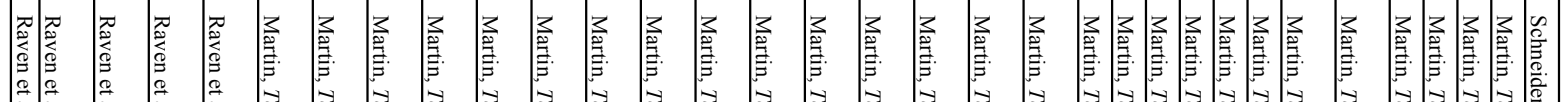

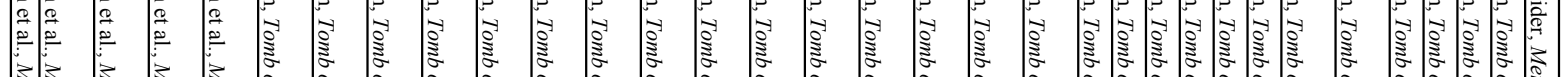

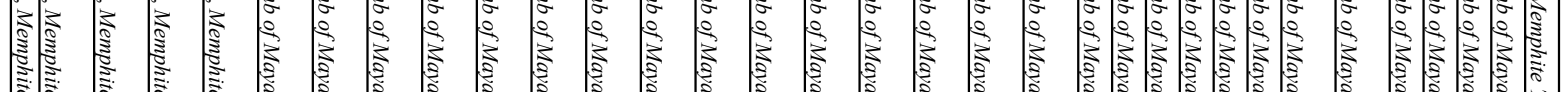

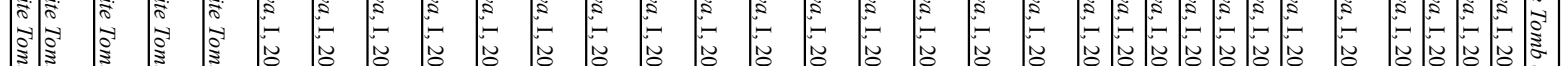

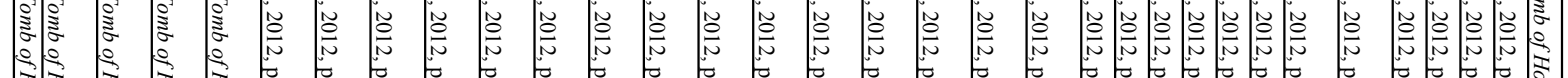
管

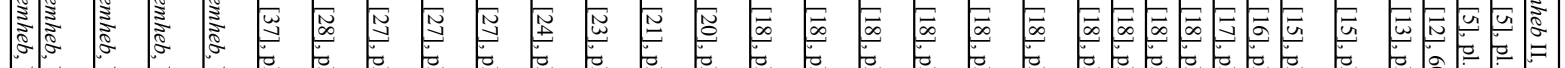

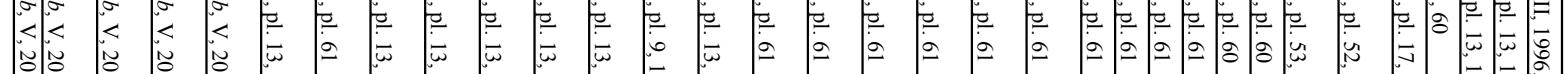

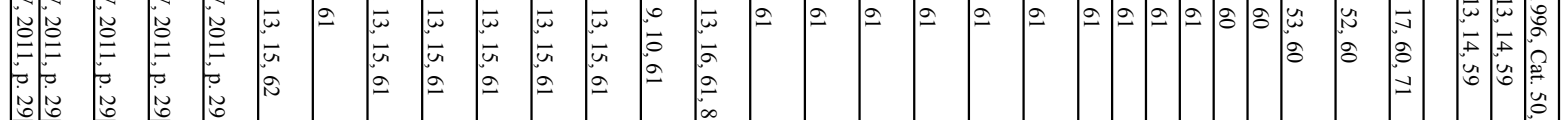

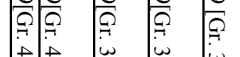

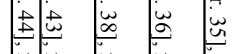
戠

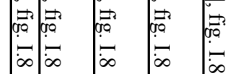




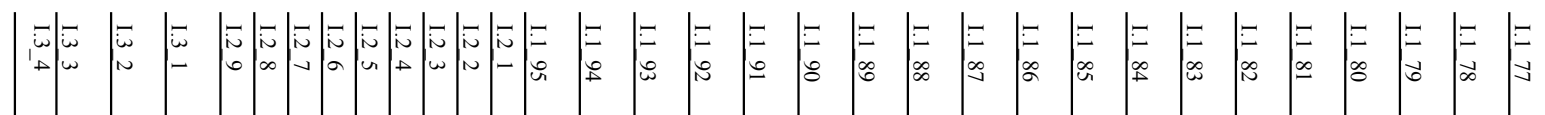

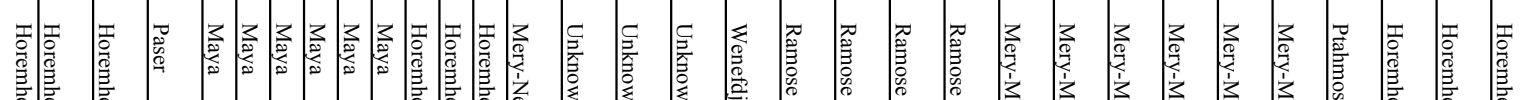

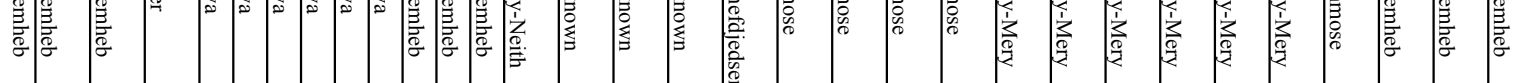

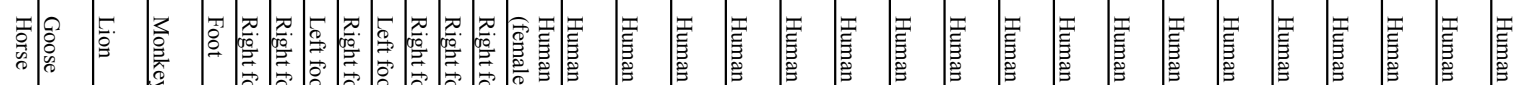

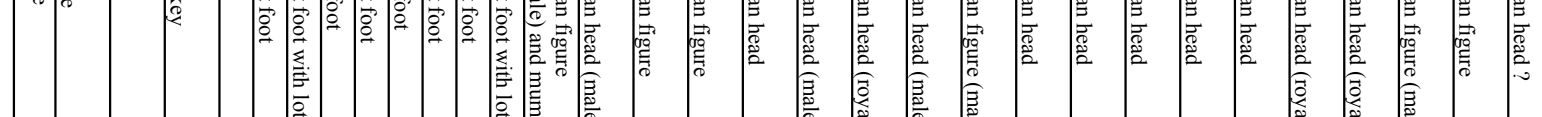

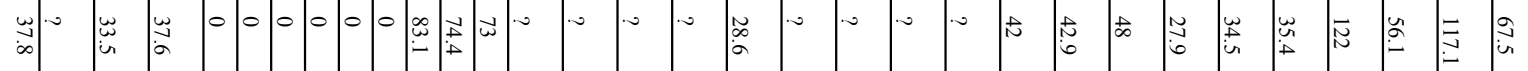

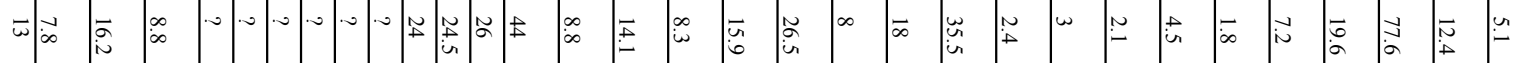

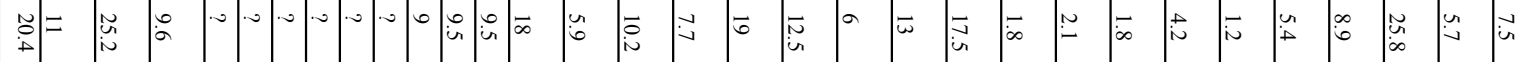

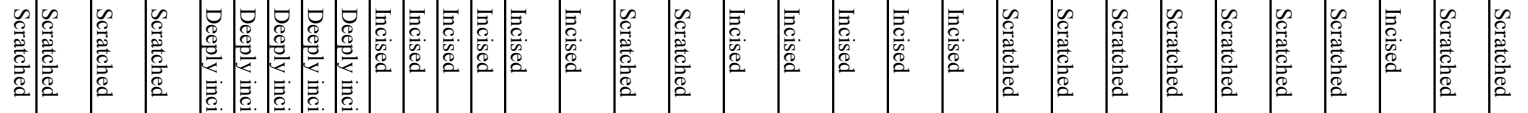

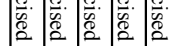

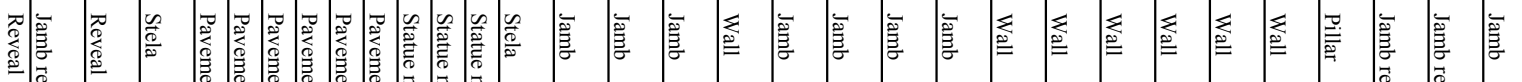

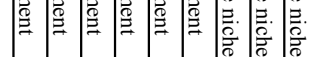

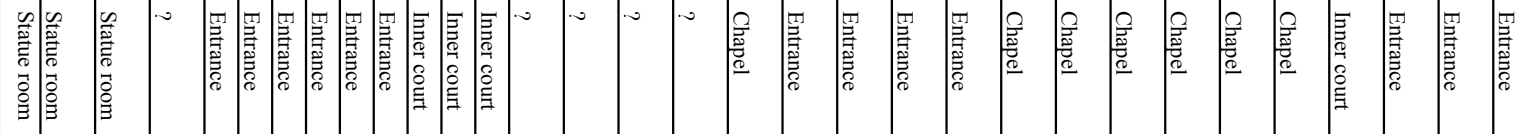

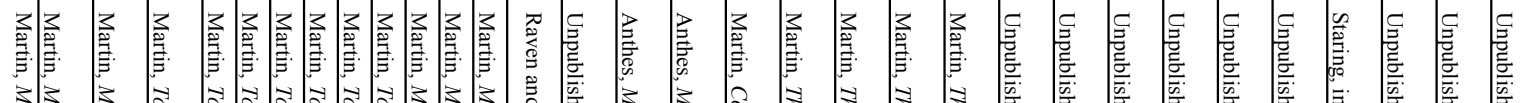

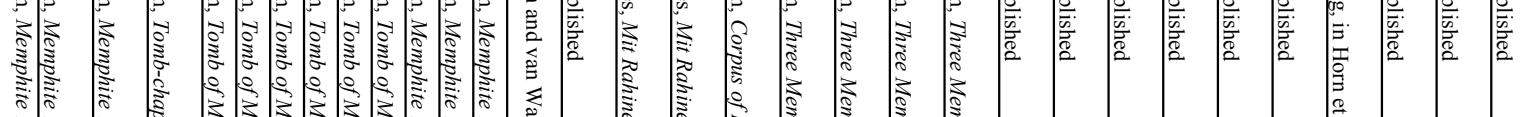

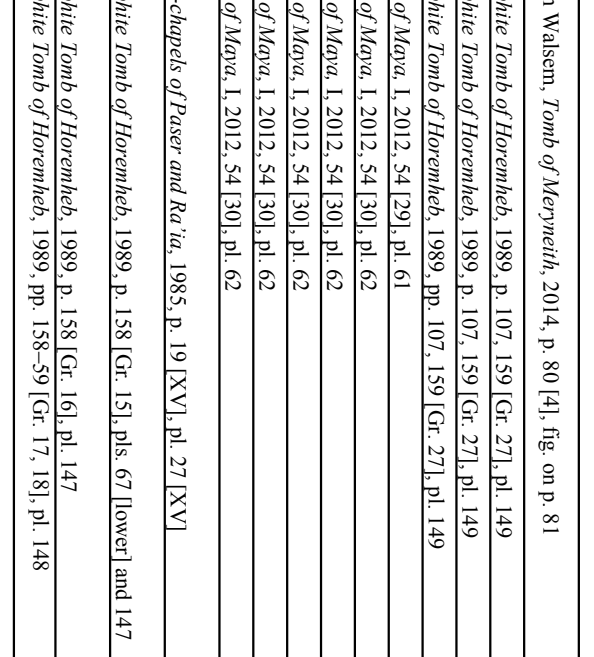

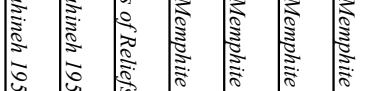

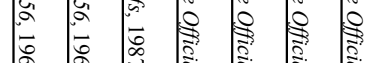

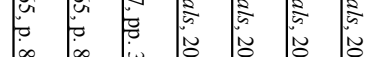
舟出

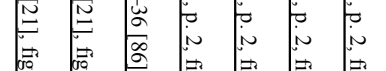

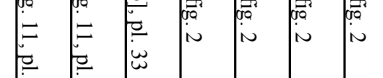
年 要 


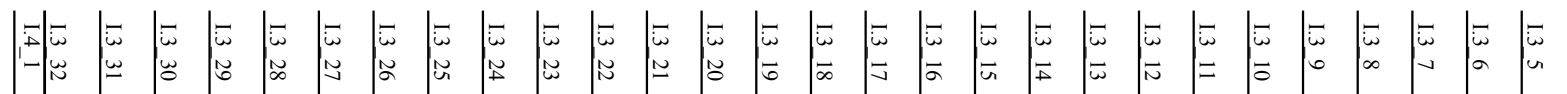

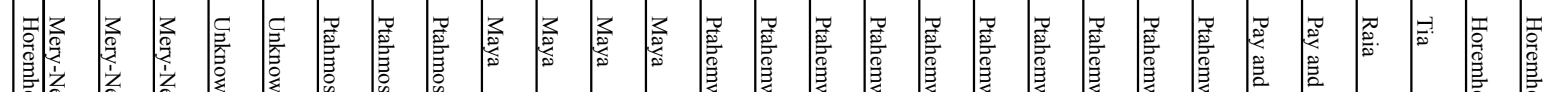

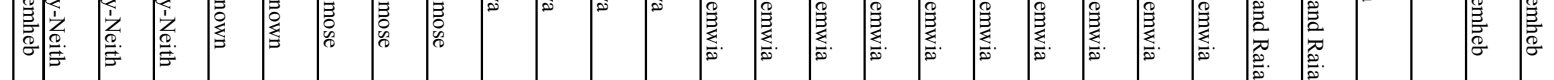

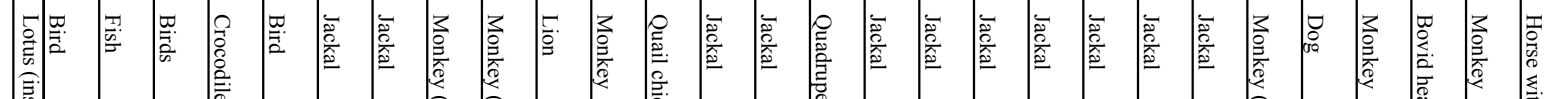

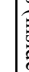

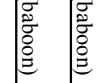

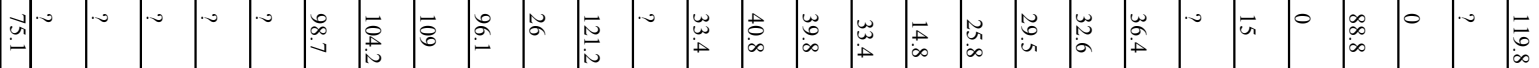

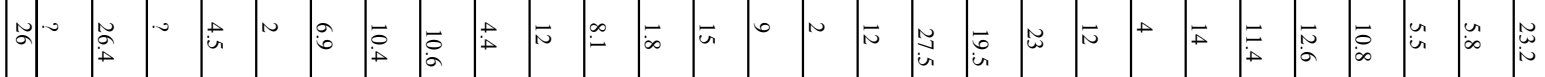

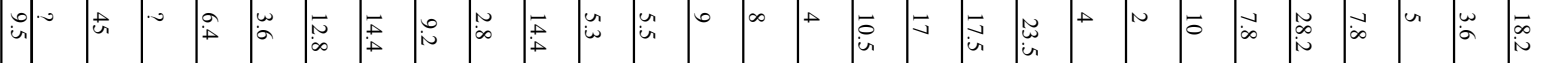

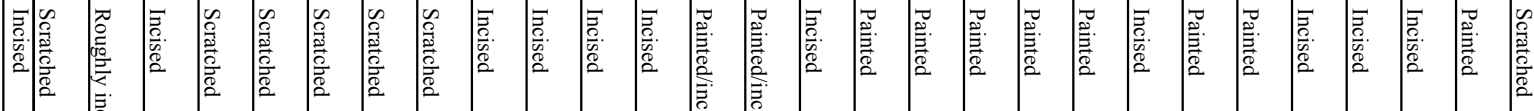

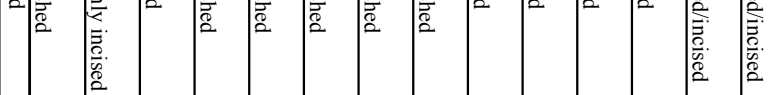

| 흘.

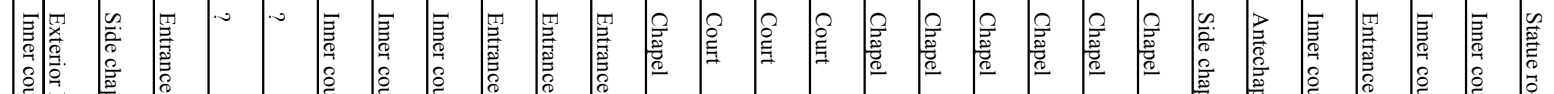

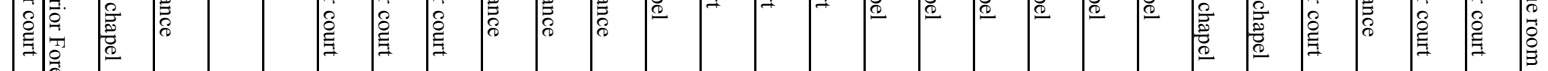

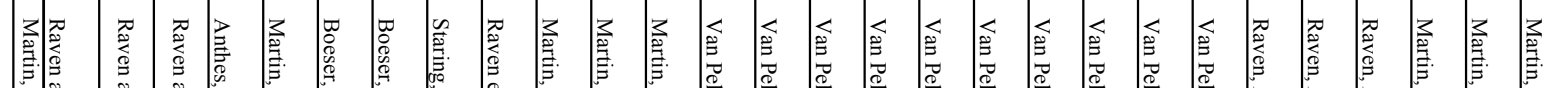

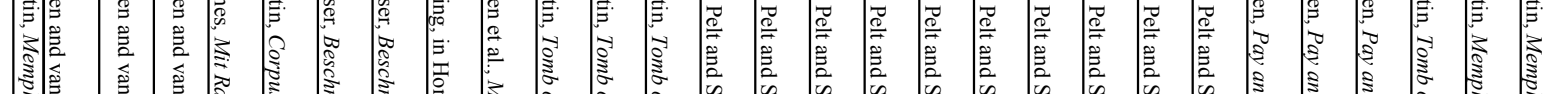

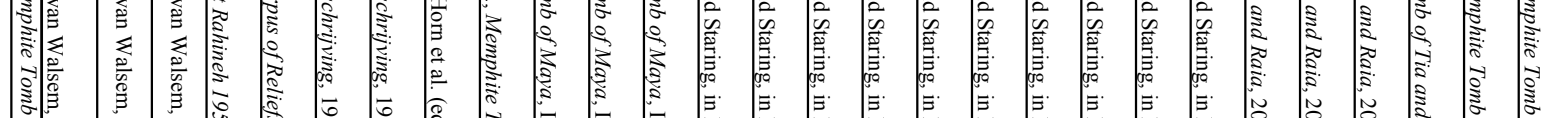

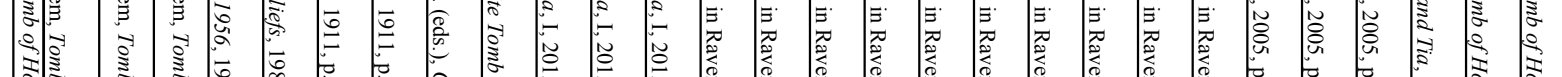

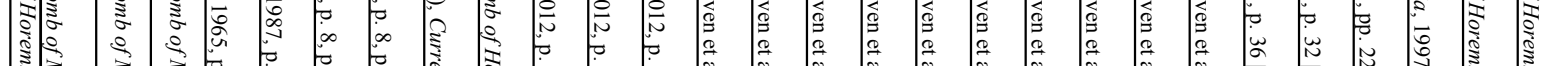

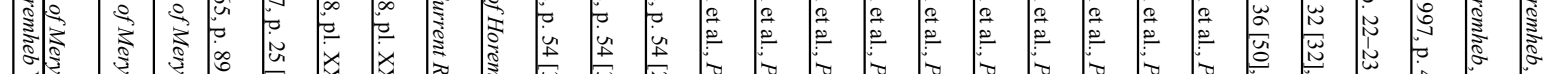

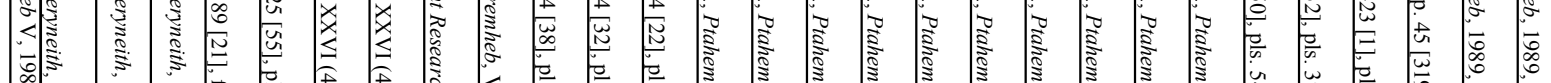

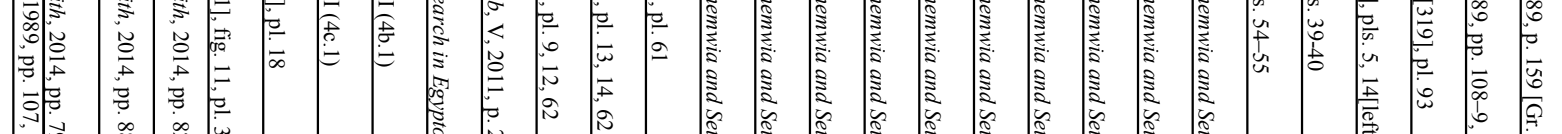

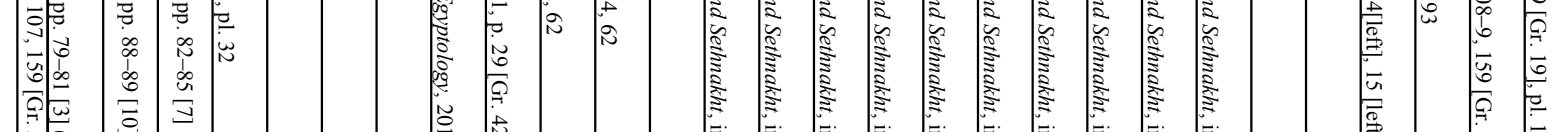

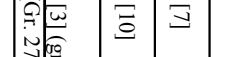
恣

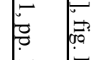
$\vec{s}$

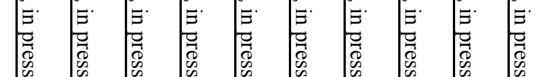

空

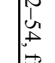

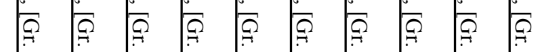

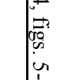

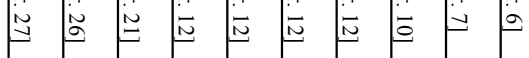
ñ 


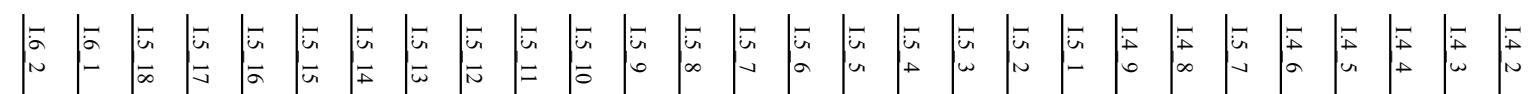

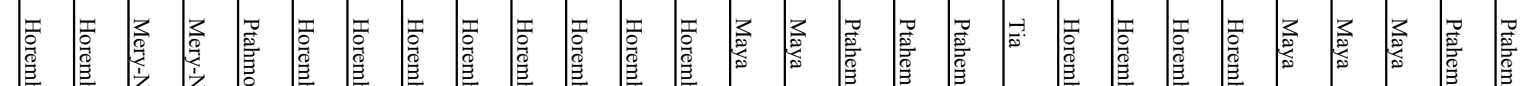

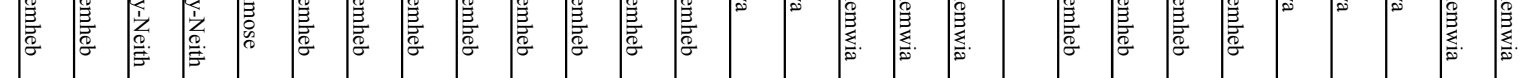

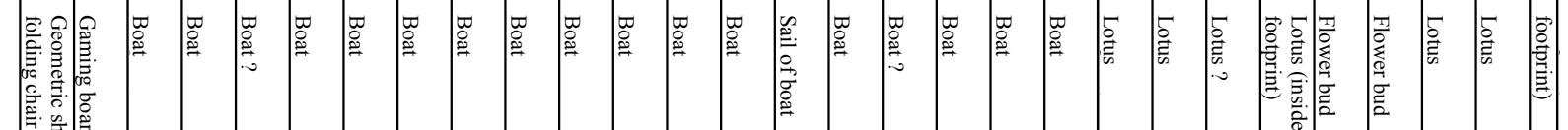

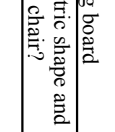

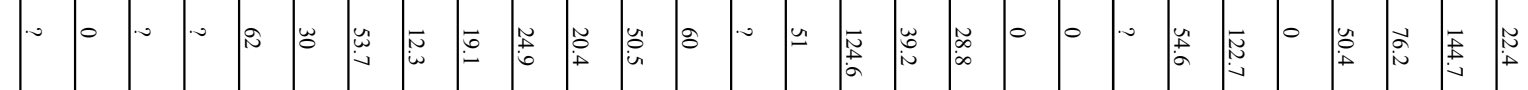

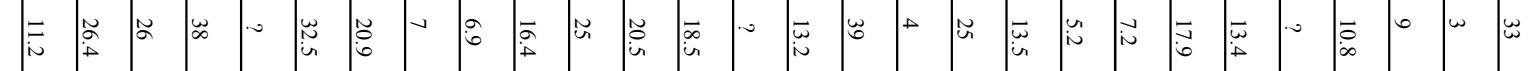

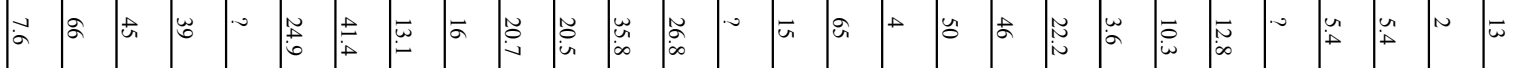

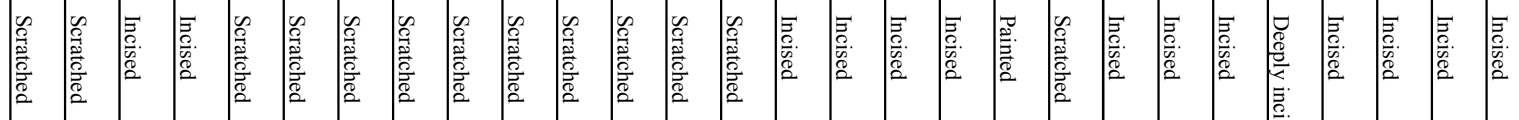

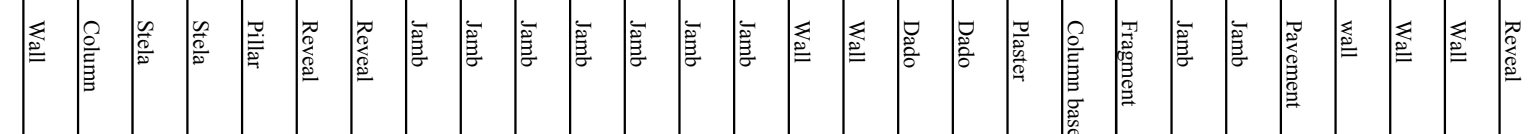

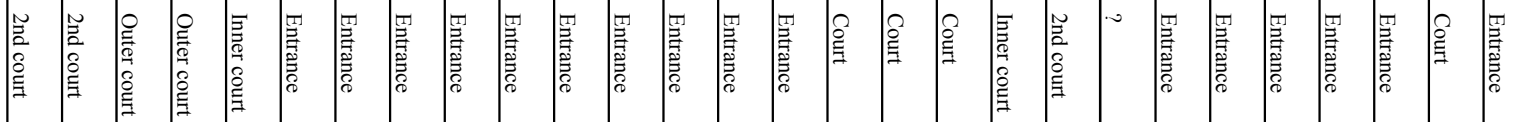

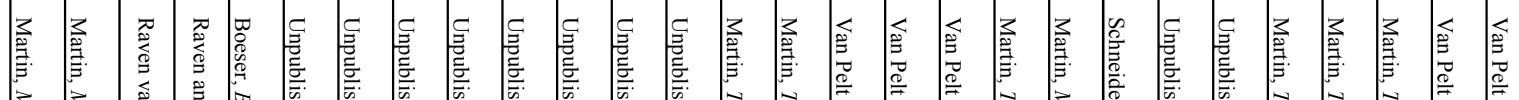

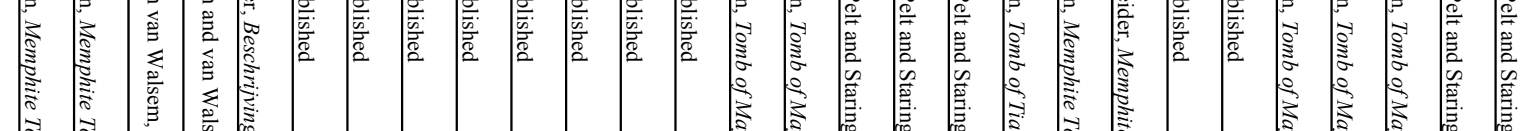

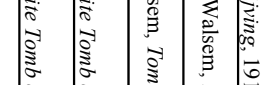

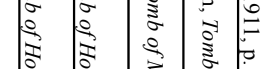

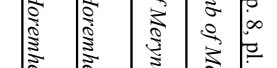

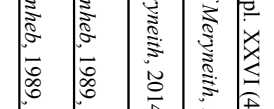

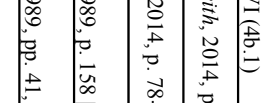

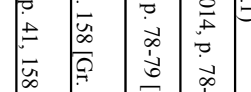

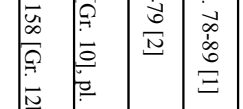

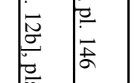

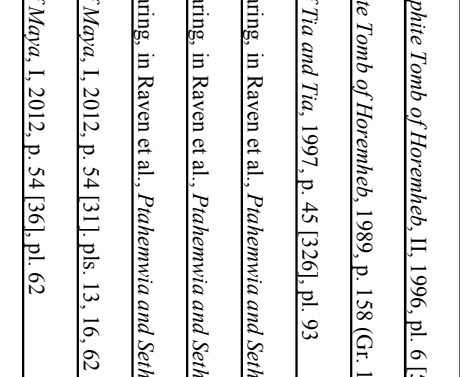

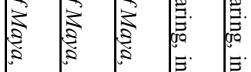

㱐

愿

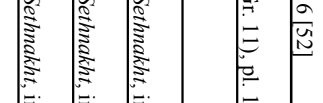

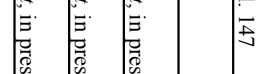

管

E

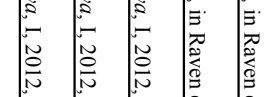

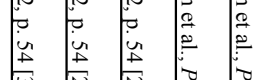

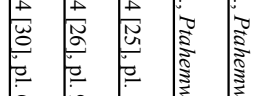

is $\bar{\omega}$

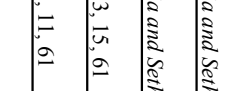

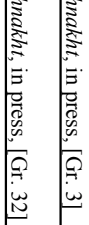

愿 


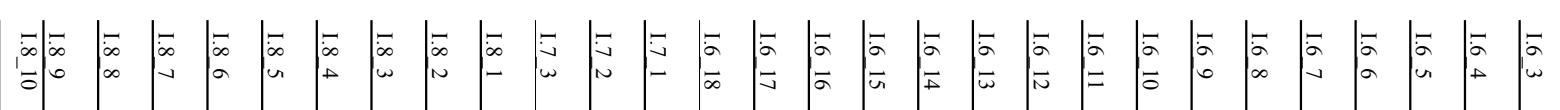

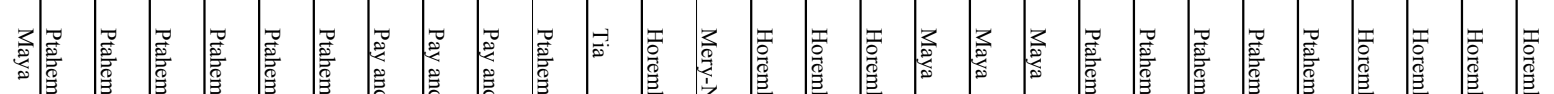

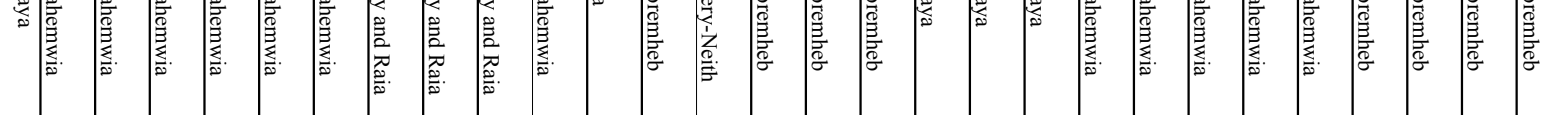

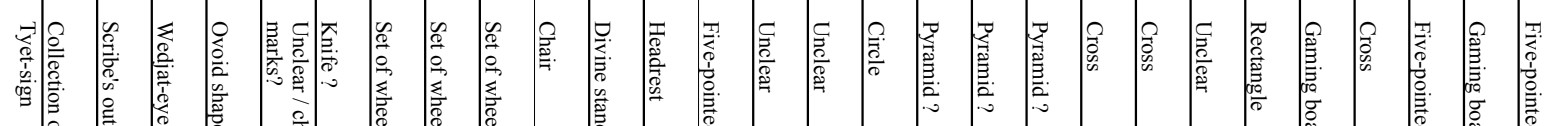

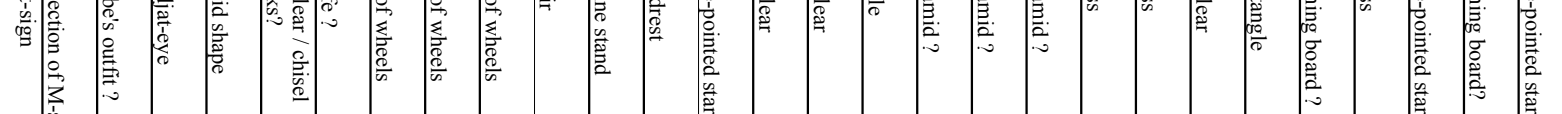

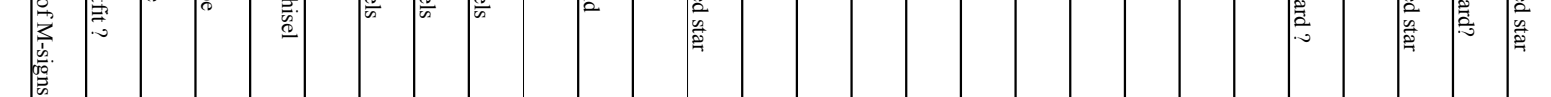

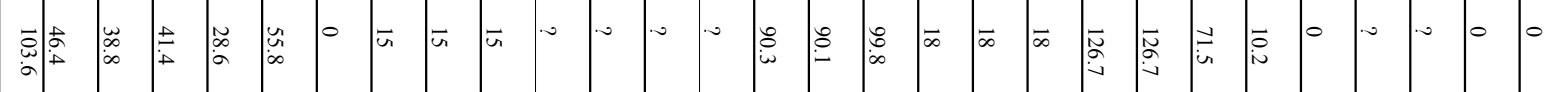

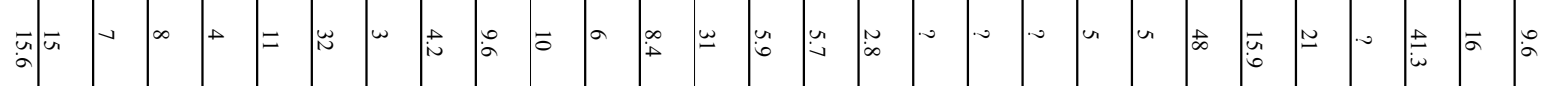

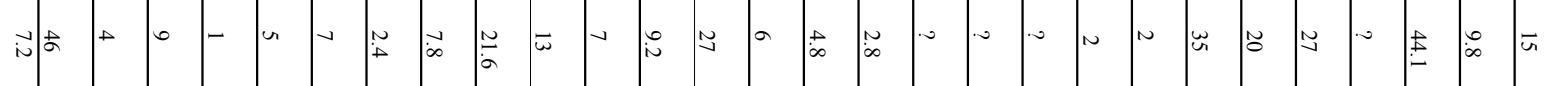

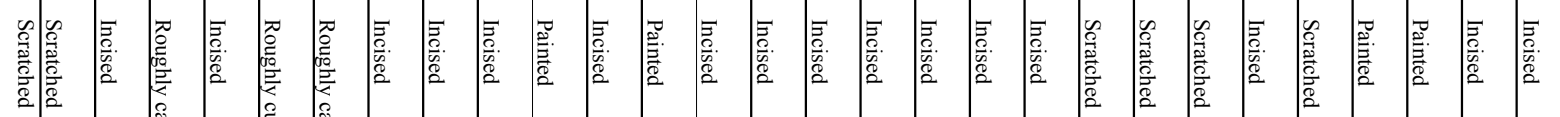

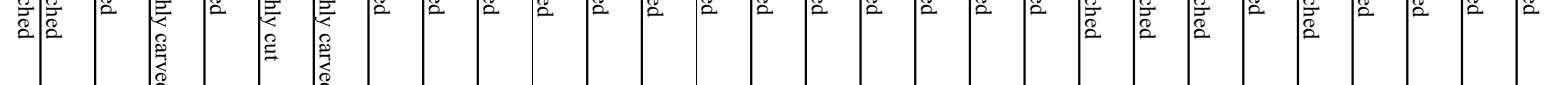

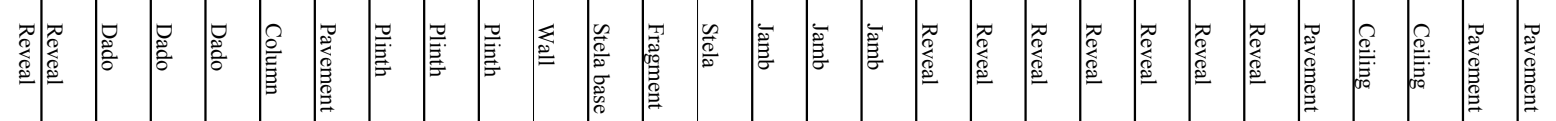

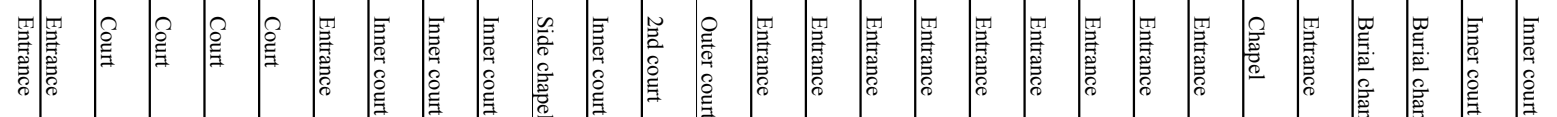

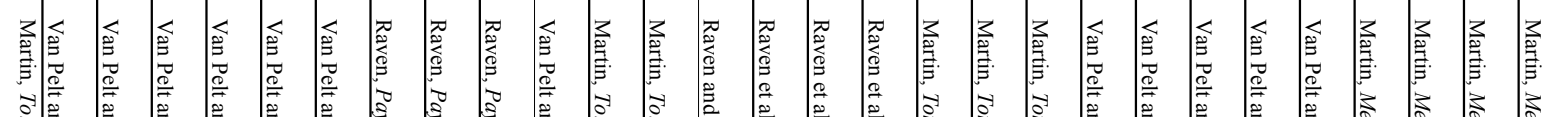

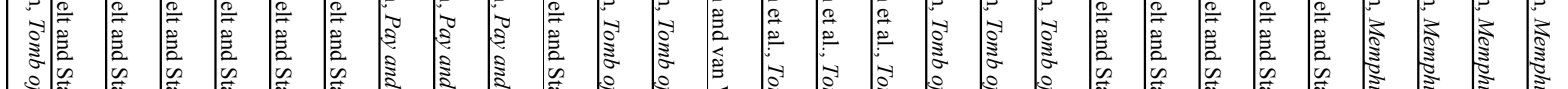

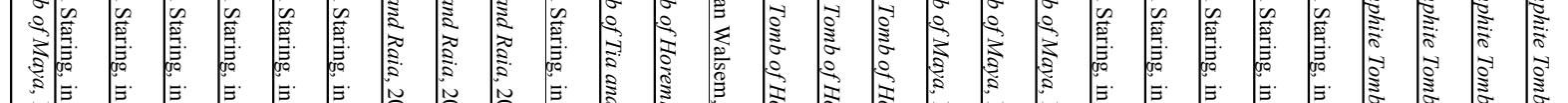

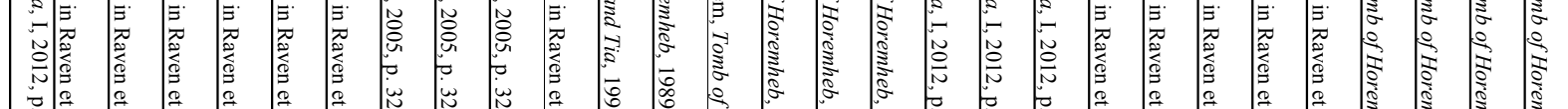

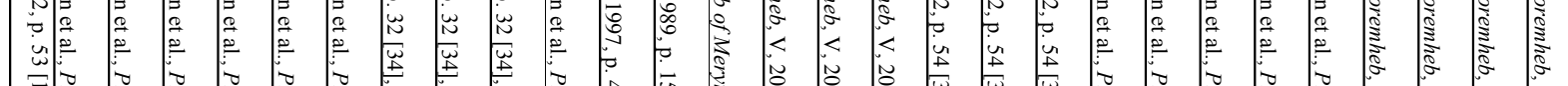

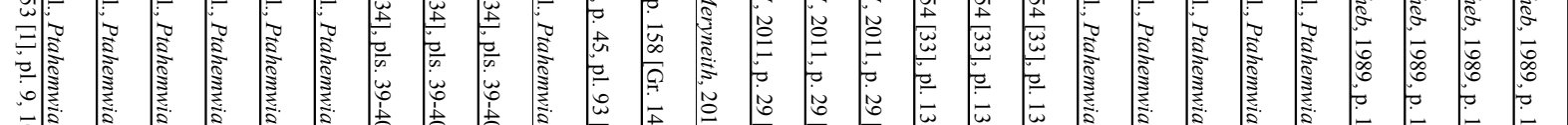

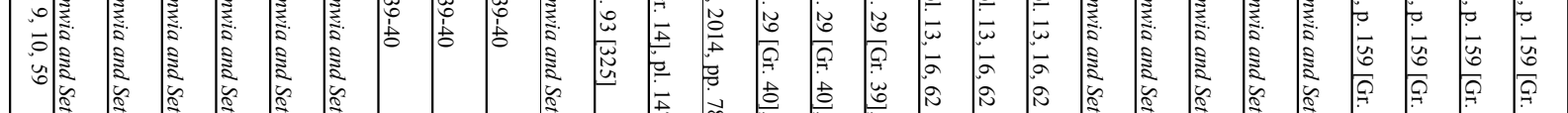

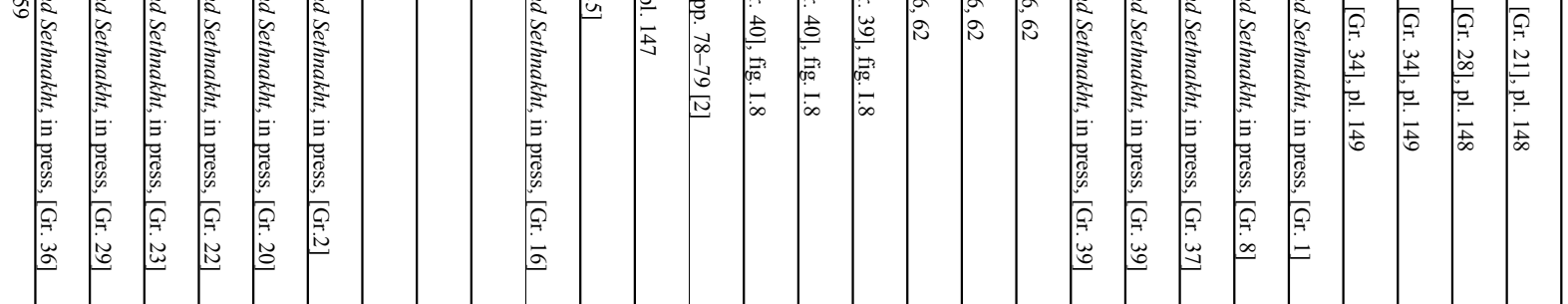




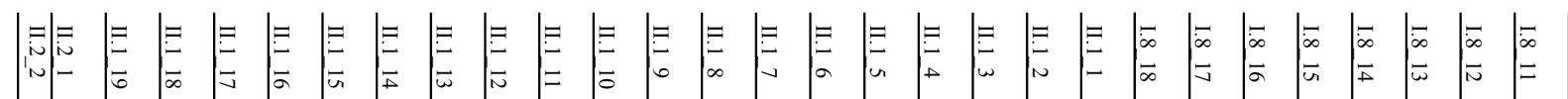

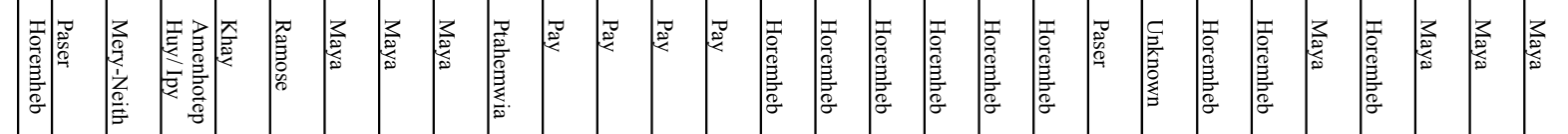

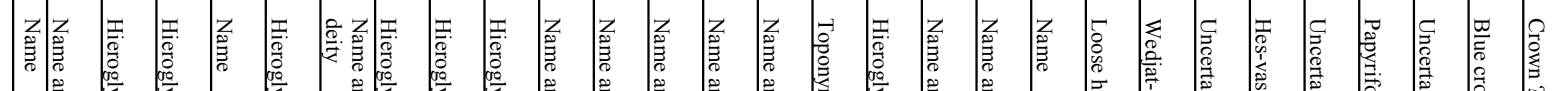

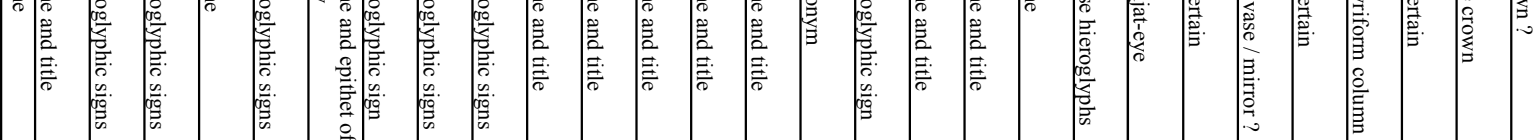
可可

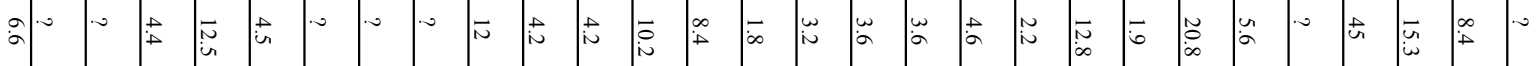

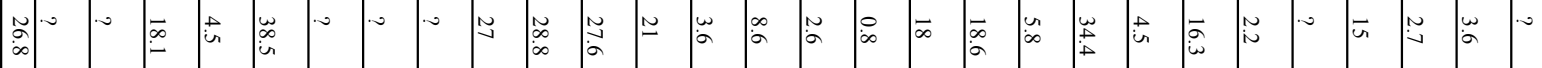

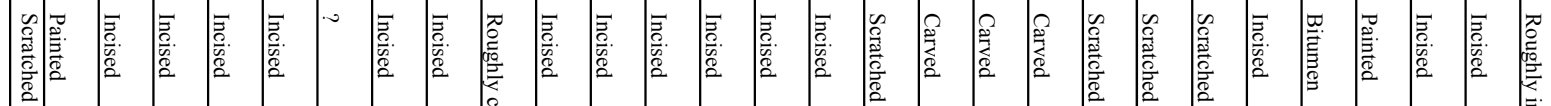
咅

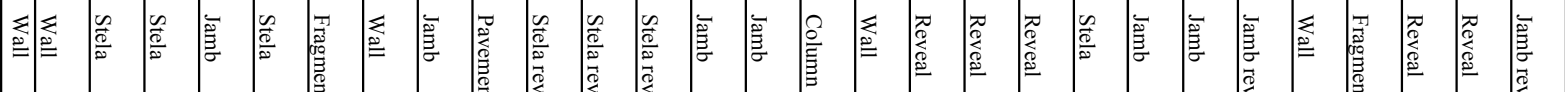

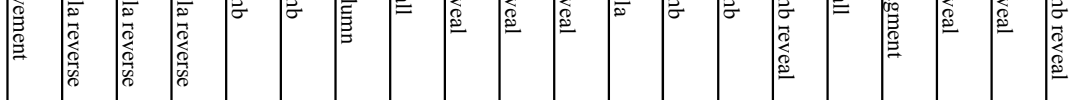

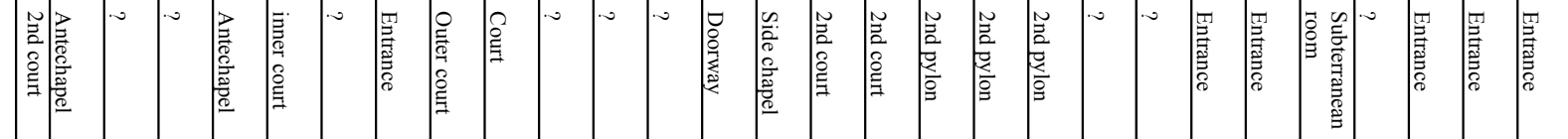

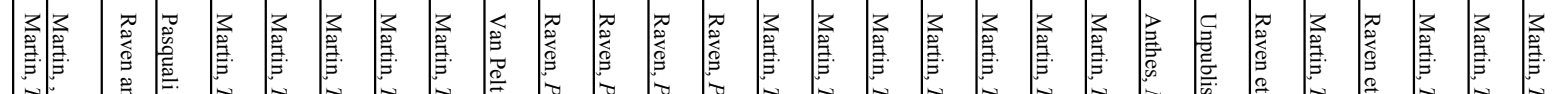

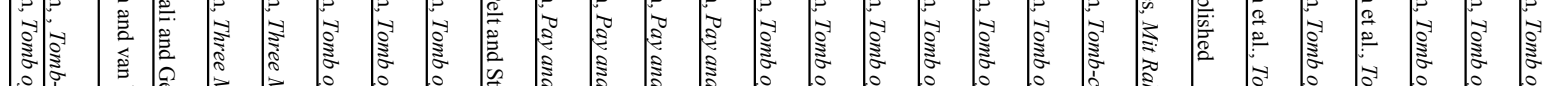

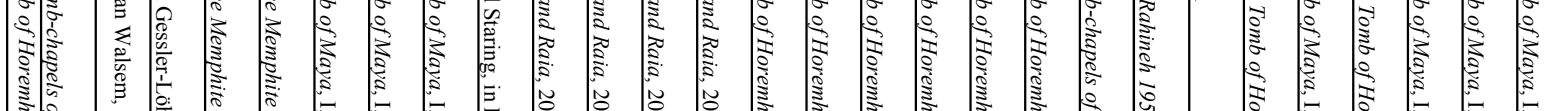

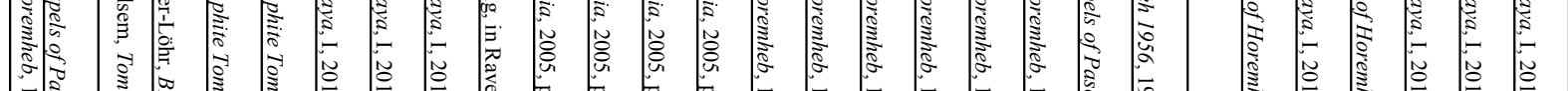

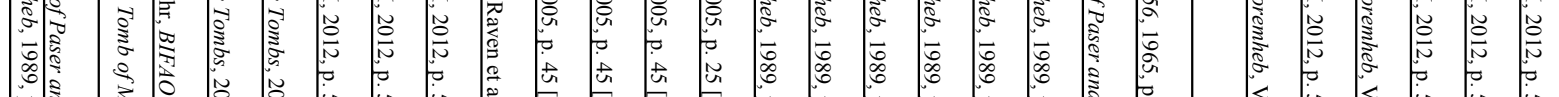

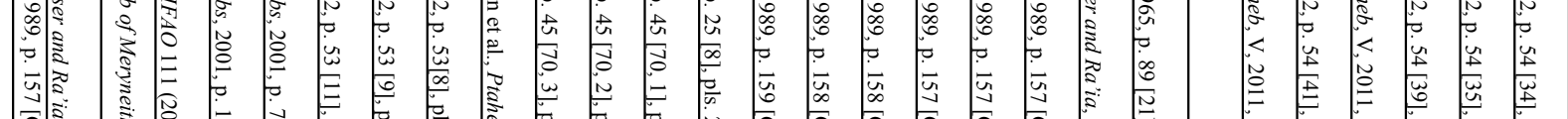

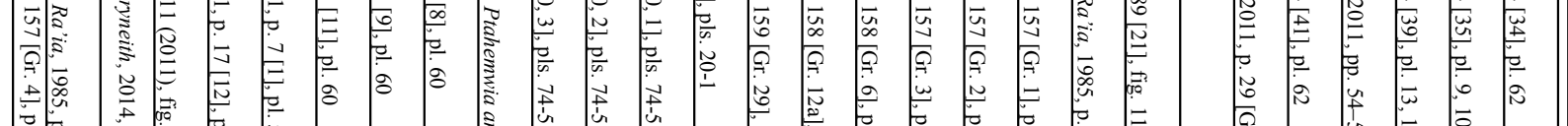

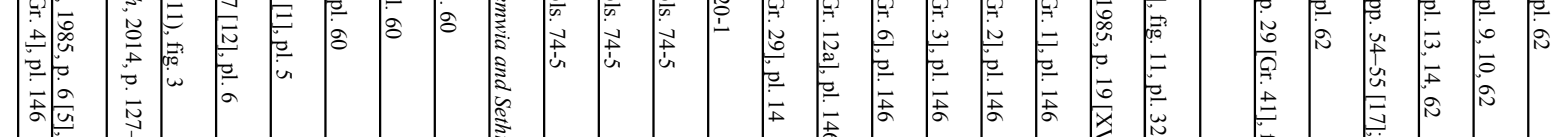

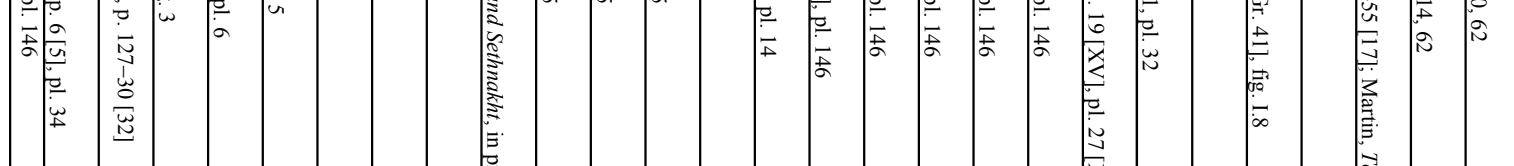

俤

象

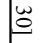




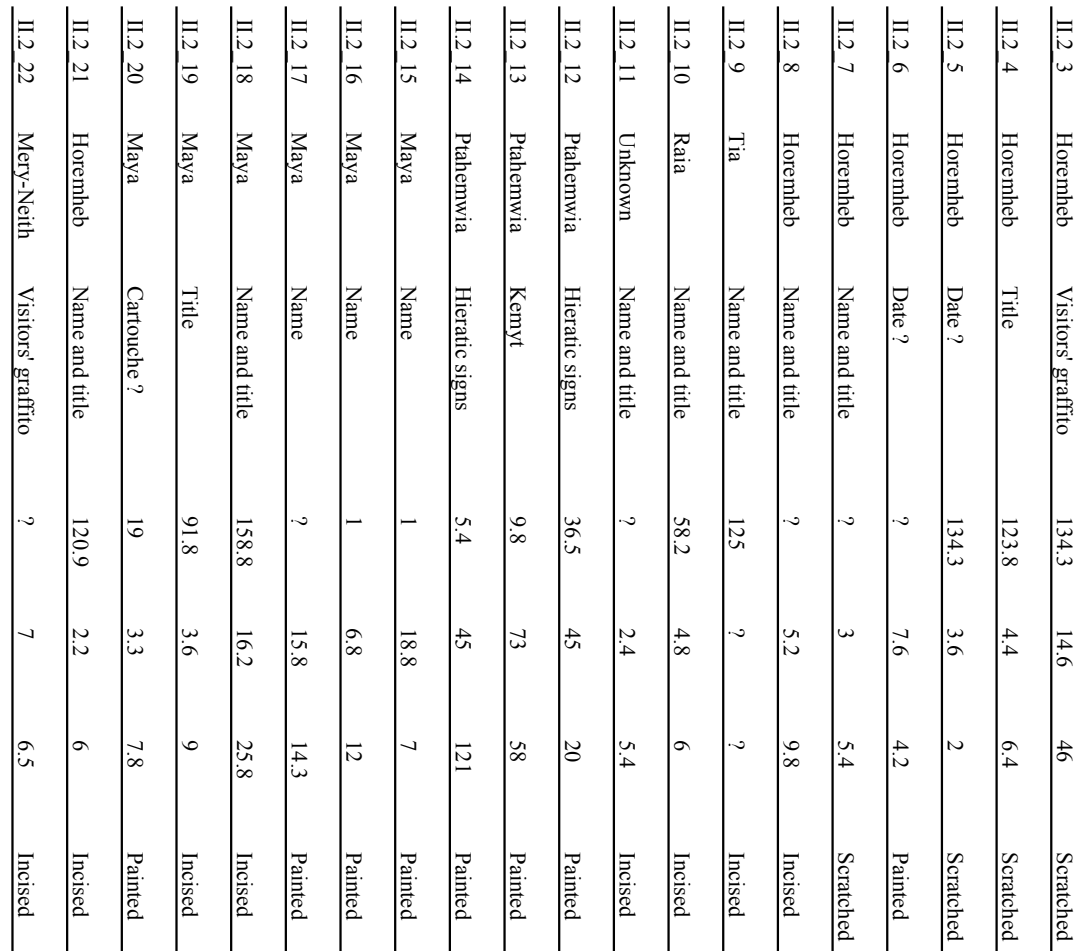

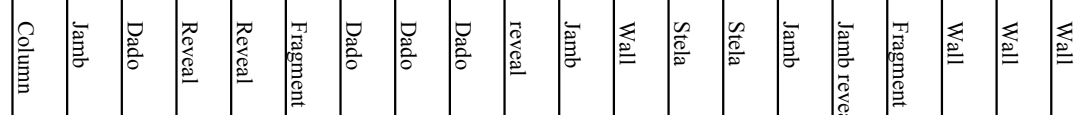

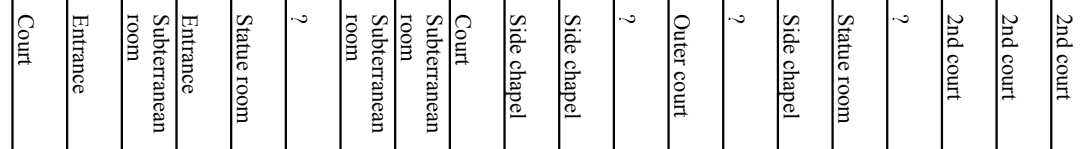

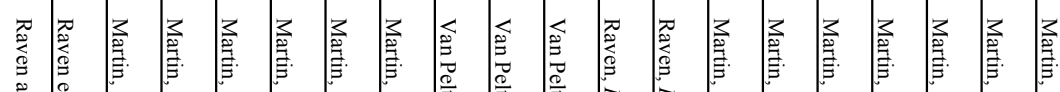

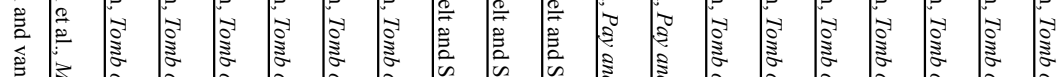

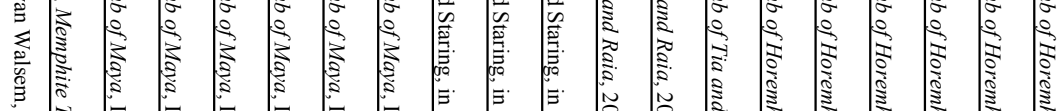

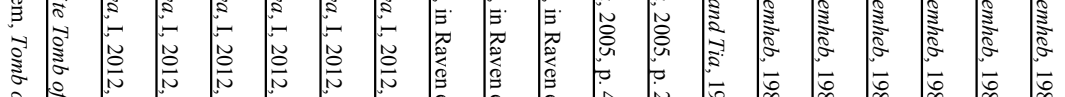

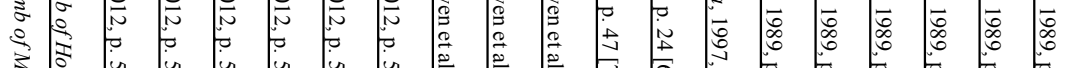

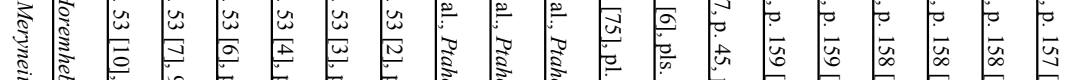

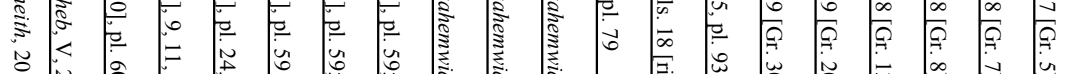

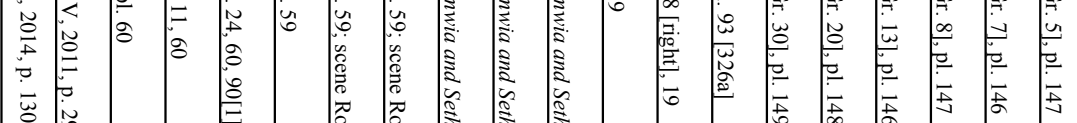

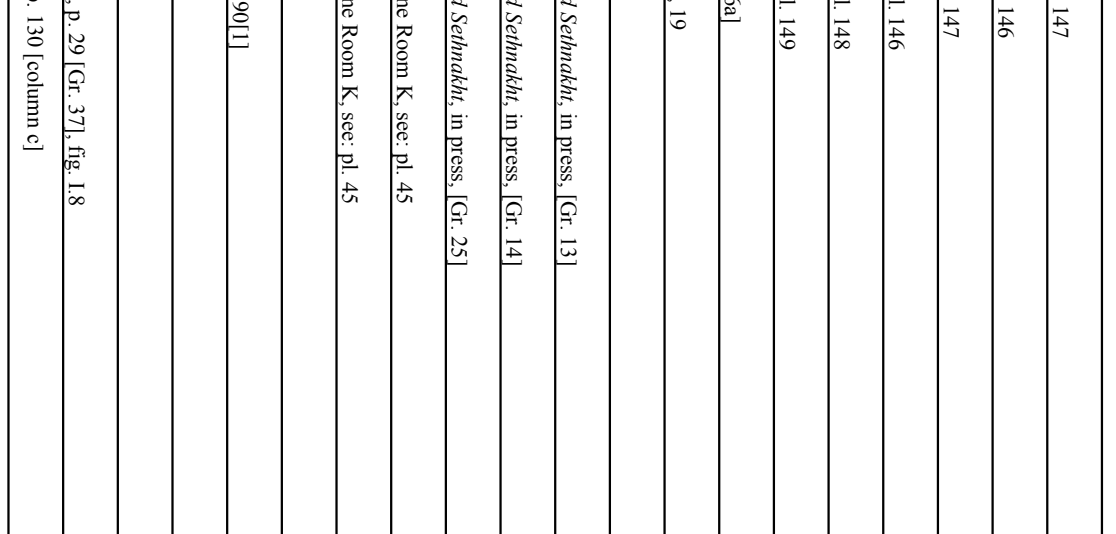

